\title{
Weatherization Works II - Summary of Findings From the ARRA Period Evaluation of the U.S. Department of Energy's Weatherization Assistance Program
}

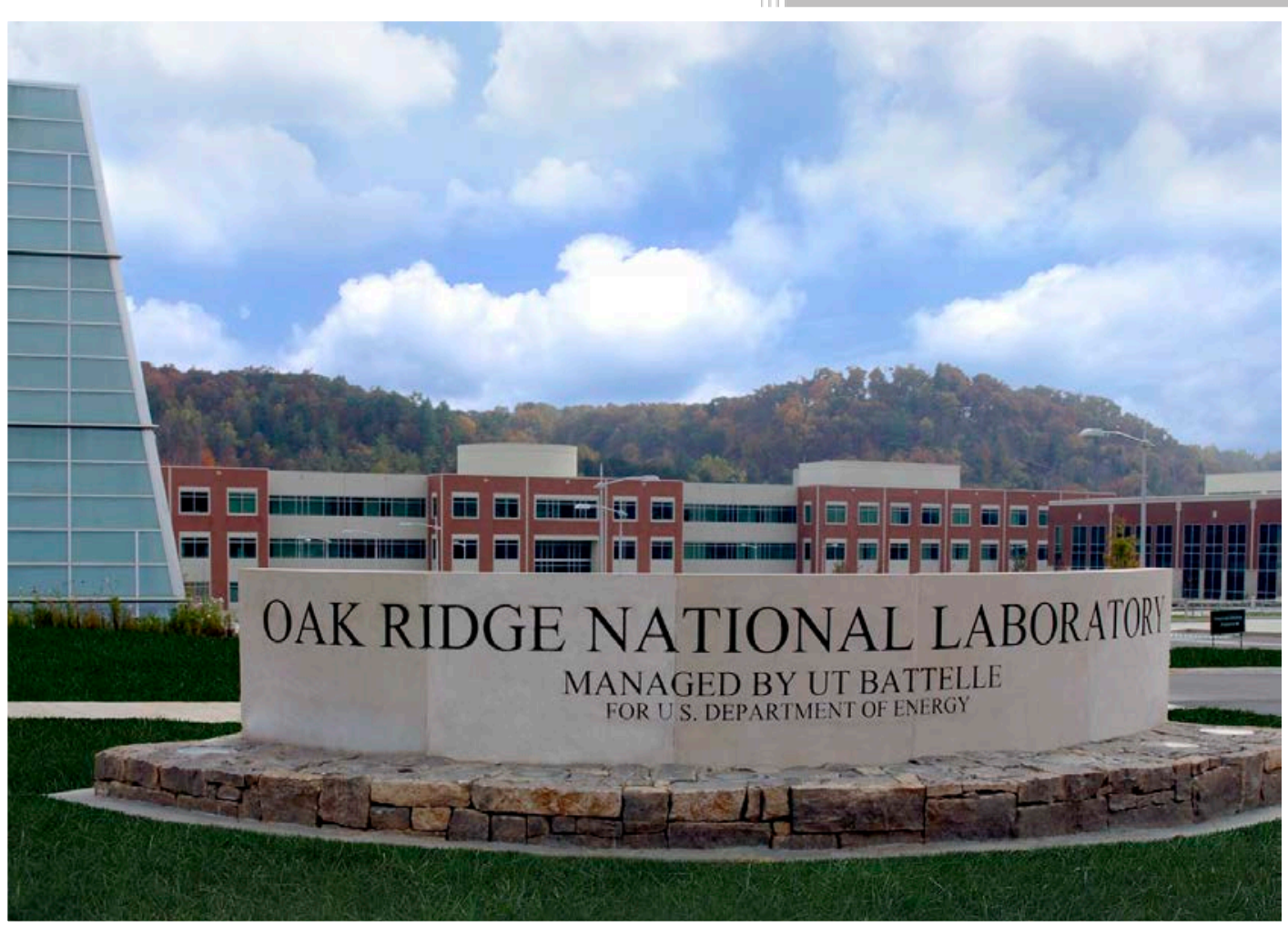

Approved for public release. Distribution is unlimited.
Bruce Tonn

David Carroll

Erin Rose

Beth Hawkins

Scott Pigg

Daniel Bausch

Greg Dalhoff

Michael Blasnik

Joel Eisenberg

Claire Cowan

Brian Conlon

July 2015 


\section{DOCUMENT AVAILABILITY}

Reports produced after January 1, 1996, are generally available free via US Department of Energy (DOE) SciTech Connect.

Website http://www.osti.gov/scitech/

Reports produced before January 1, 1996, may be purchased by members of the public from the following source:

National Technical Information Service

5285 Port Royal Road

Springfield, VA 22161

Telephone 703-605-6000 (1-800-553-6847)

TDD 703-487-4639

Fax 703-605-6900

E-mail info@ntis.gov

Website http://www.ntis.gov/help/ordermethods.aspx

Reports are available to DOE employees, DOE contractors, Energy Technology Data Exchange representatives, and International Nuclear Information System representatives from the following source:

Office of Scientific and Technical Information

PO Box 62

Oak Ridge, TN 37831

Telephone 865-576-8401

Fax 865-576-5728

E-mail reports@osti.gov

Website http://www.osti.gov/contact.html

This report was prepared as an account of work sponsored by an agency of the United States Government. Neither the United States Government nor any agency thereof, nor any of their employees, makes any warranty, express or implied, or assumes any legal liability or responsibility for the accuracy, completeness, or usefulness of any information, apparatus, product, or process disclosed, or represents that its use would not infringe privately owned rights. Reference herein to any specific commercial product, process, or service by trade name, trademark, manufacturer, or otherwise, does not necessarily constitute or imply its endorsement, recommendation, or favoring by the United States Government or any agency thereof. The views and opinions of authors expressed herein do not necessarily state or reflect those of the United States Government or any agency thereof. 
ORNL/TM-2015/139

Environmental Sciences Division

\title{
WEATHERIZATION WORKS II - SUMMARY OF FINDINGS FROM THE ARRA PERIOD EVALUATION OF THE U.S. DEPARTMENT OF ENERGY'S WEATHERIZATION ASSISTANCE PROGRAM
}

\author{
Bruce Tonn, Oak Ridge National Laboratory \\ David Carroll, APPRISE Inc. \\ Erin Rose, Oak Ridge National Laboratory \\ Beth Hawkins, Oak Ridge National Laboratory \\ Scott Pigg, Energy Center of Wisconsin \\ Daniel Bausch, APPRISE Inc. \\ Greg Dalhoff, Dalhoff \& Associates \\ Michael Blasnik, Google. \\ Joel Eisenberg, Oak Ridge National Laboratory \\ Claire Cowan, Energy Center of Wisconsin \\ Brian Conlon, Oak Ridge National Laboratory
}

July 2015

Prepared by

OAK RIDGE NATIONAL LABORATORY

Oak Ridge, Tennessee 37831-6283

managed by

UT-BATTELLE, LLC

for the

US DEPARTMENT OF ENERGY

under contract DE-AC05-00OR22725 



\section{CONTENTS}

CONTENTS. .. iii

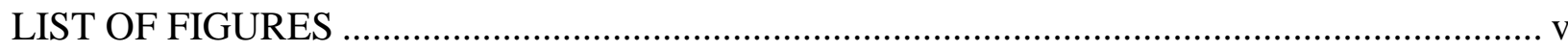

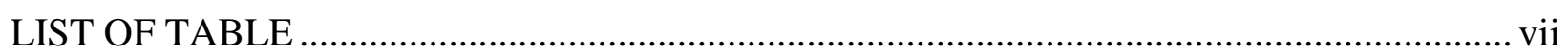

ACRONYMS AND ABBREVIATIONS ...................................................................... ix

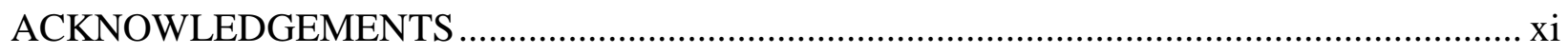

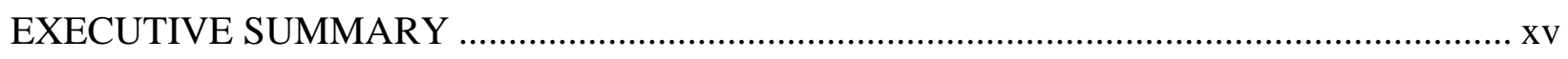

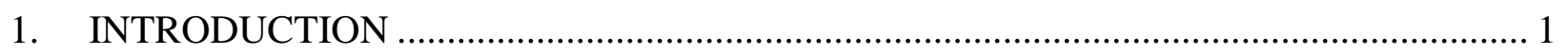

2. WAP DURING THE RECOVERY ACT PERIOD ........................................................ 3

2.1 PRODUCTION AND EXPENDITURES .............................................................. 3

2.2 THE RECOVERY ACT EXPERIENCE ............................................................. 9

2.3 ENERGY SAVINGS ESTIMATES ..................................................................... 12

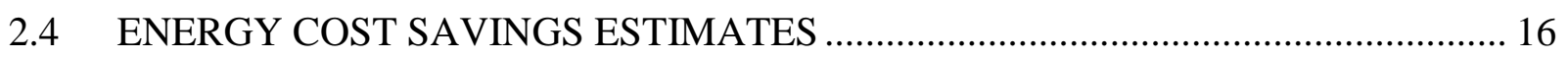

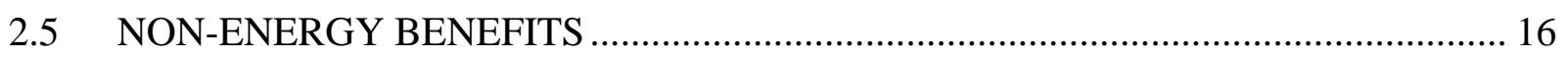

2.5.1 Environmental Benefits ...................................................................... 17

2.5.2 Macroeconomic Benefits ....................................................................... 19

2.5.3 Health and Household-Benefits .................................................................... 20

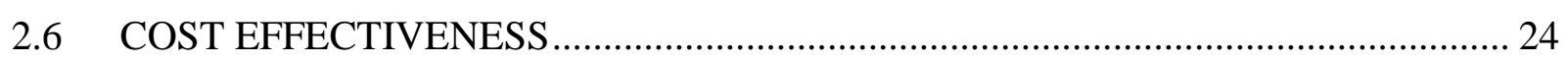

2.7 COST EFFECTIVENESS: COMPARISON OF APPROACHES ............................. 26

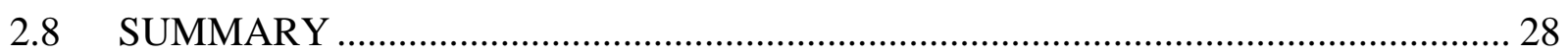

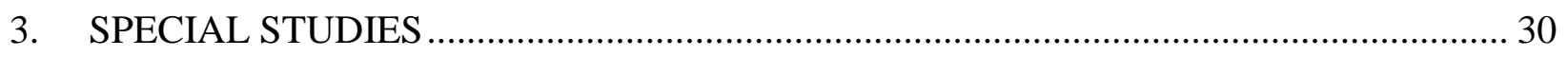

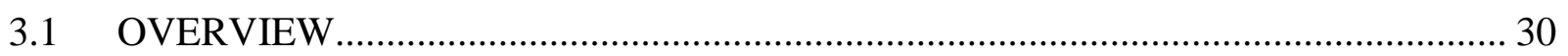

3.2 WEATHERIZATION PLUS HEALTH - OPPORTUNITY COUNCIL ..................... 30

3.3 WEATHERIZATION EXPERIENCES SOCIAL NETWORKING STUDY.............. 32

3.4 OCCUPANT SURVEY ANALYSES - BUDGETS, ENERGY BEHAVIORS ........... 33

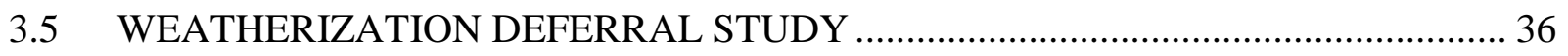

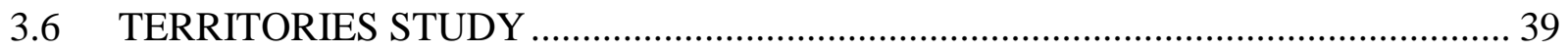

3.7 WEATHERIZATION POST-RECOVERY ACT SURVEY RESULTS ................... 40

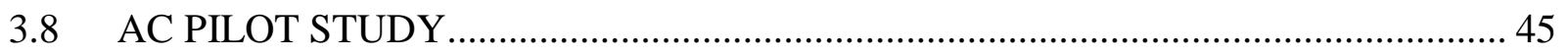

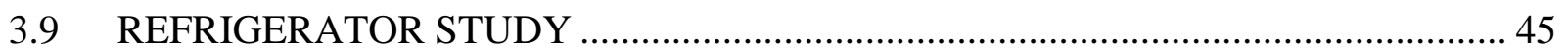

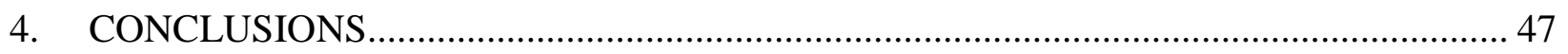

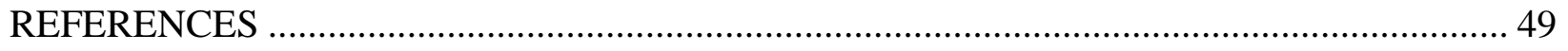

APPENDIX. SUMMARY OF ARRA PERIOD EVALUATION DATA COLLECTION ACTIVITIES. 



\section{LIST OF FIGURES}

Figure $\quad$ Page

Figure 2.1 DOE WAP Expenditures during the Recovery Act Period ....................................... 4

Figure 2.2 Weatherization Employment Supported by Recovery Act Funds.............................. 4

Figure 2.3 Units Weatherized Using ARRA and Normal Appropriations (Formula) Funding...... 5

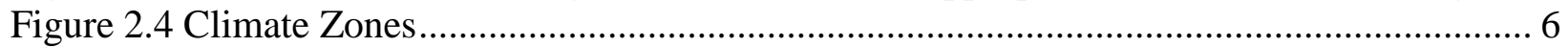

Figure 2.5 Clusters of Subgrantees by Funding Levels and Source PY 2008 and PY 2010 ......... 9

Figure 2.6 Estimated Energy Savings in Site Built Homes PY 2007 to 2011 by Climate Zone .. 14

Figure 2.7 Estimated Energy Savings in Mobile Homes PY 2007 to 2011 by Climate Zone...... 15

Figure 2.7 Framework for Understanding Non-Energy Benefits (solid lines represent direct, or first-order, pathways; dotted lines represent indirect, or second-order, pathways) .................... 17

Figure 2.8 Potential Impacts of Weatherization on Household Disposable Income ................... 21

Figure 2.9 Cost-Effectiveness of Site Built Homes by Climate Zone, Heating Fuel Type, and

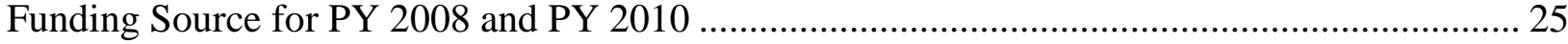

Figure 2.10 Cost-Effectiveness of Mobile Homes by Climate Zone, Heating Fuel Type, and Funding Source for PY 2008 and PY 2010 ................................................................... 26

Figure 3.1. Employment status at time of training and two years later .................................. 43

Figure 3.2. Current employers of trainees no longer working in low-income weatherization ..... 43

Figure 3.3. Current employers of trainees still working in low-income weatherization ............. 44

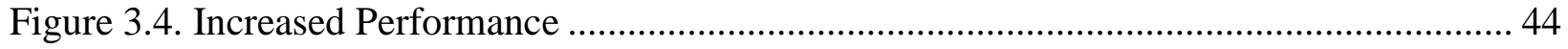

Figure 3.5. Increased Marketability .............................................................................. 44 



\section{LIST OF TABLE}

Table

Page

Table 2.1 Weatherized Units in Program Years 2008 and 2010 by Housing Type...................... 5

Table 2.2 Weatherized Units in Program Years 2008 and 2010 by Climate Zone....................... 6

Table 2.3. PY 2010 Clients Shell Measures by Building Type ............................................... 7

Table 2.4 Major Measures Installed Single Family and Mobile Homes .................................. 8

Table 2.5 DOE and Leveraged Weatherization Funding in PY 2010 and PY 2008 (\$ millions)... 8

Table 2.6 Estimated Energy Savings by House Type for PY 2008 and 2010 ........................... 13

Table 2.7 Large Multifamily Building Energy Savings (per unit).......................................... 16

Table 2.8 Summary of Energy Cost Savings by House Type and Program Year ...................... 16

Table 2.9 Emissions Reductions Attributable to WAP for PY 2008 and PY 2010 .................... 19

Table 2.10 Present Value of Per Unit and WAP Program (ARRA period) Health-Related

Benefits of Weatherization

Table 2.11 Energy Cost Savings, Efficiency Measure Costs, and Cost-Effectiveness by Building

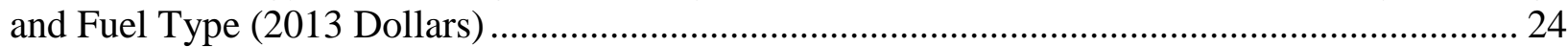

Table 2.12. Total Benefits and Costs for WAP PY2008 \& PY 2010 ........................................ 27

Table 2.13 Total (Program) Benefits and Costs for WAP PY 2010: Comparison of Approaches28

Table 2.14 Single Family Benefits and Costs for WAP PY 2010: Comparison of Approaches .. 28

Table 3.1 Employment Status of Weatherization Staff Respondents in 2013 ........................... 41

Table 3.2 Employment Tenure and Age of Respondents in 2011 ........................................ 42

Table A.1. Major Data Collection Activities .................................................................... 3

Table A.2. Field Study Data Collection Activities ................................................................. 4 



\section{ACRONYMS AND ABBREVIATIONS}

$\begin{array}{ll}\text { APEEP } & \text { Air Pollution Emission and Policy Analysis Model } \\ \text { ARRA } & \text { American Recovery and Reinvestment Act } \\ \text { BPI } & \text { Building Performance Institute } \\ \text { BTU } & \text { British Thermal Unit } \\ \text { CFR } & \text { Code of Federal Regulations } \\ \text { CO }_{2} & \text { Carbon dioxide } \\ \text { DOE } & \text { U.S. Department of Energy } \\ \text { ECM } & \text { Energy conservation measure } \\ \text { EPA } & \text { Environmental Protection Agency } \\ \text { KWH } & \text { Kilowatt hours } \\ \text { LIHEAP } & \text { Low Income Home Energy Assistance Program } \\ \text { LMF } & \text { Large multifamily building } \\ \text { MH } & \text { Mobile home } \\ \text { MMBTu } & \text { Million British Thermal Units } \\ \text { NG } & \text { Natural gas } \\ \text { NO } & \text { Nitrogen oxide } \\ \text { NRC } & \text { National Research Council } \\ \text { NYC } & \text { New York City } \\ \text { OMB } & \text { Office of Management and Budget } \\ \text { ORNL } & \text { Oak Ridge National Laboratory } \\ \text { OWIP } & \text { Office of Weatherization and Intergovernmental Programs } \\ \text { PIPP } & \text { Percentage of Income Payment Program } \\ \text { PM } & \text { Particulate matter } \\ \text { PY } & \text { Program Year } \\ \text { REMI } & \text { Regional Economic Models, Inc. } \\ \text { SERC } & \text { Sustainable Energy Resources for Consumers Program } \\ \text { SF } & \text { Single family } \\ \text { SIR } & \text { Savings-to-investment ratio } \\ \text { SMF } & \text { Small multifamily } \\ \text { SOx } & \text { Sulfur oxide } \\ \text { T\&TA } & \text { Training and technical assistance } \\ \text { THERM } & \text { 100,000 British Thermal Units } \\ \text { VOCS } & \text { Volatile organic compounds } \\ \text { WAP } & \text { Weatherization Assistance Program } \\ \text { WHO } & \text { World Health Organization } \\ & \\ & \end{array}$




\section{ACKNOWLEDGEMENTS}

The work presented in this report was funded by the U.S. Department of Energy's (DOE) Office of Weatherization and Intergovernmental Programs (OWIP).

Numerous individuals beyond the lengthy list of authors of this summary report contributed to the retrospective evaluation of DOE's Weatherization Assistance Program. Others who are listed as coauthors of the various retrospective evaluation reports include: Paul Francisco, Tim Lenahan, Daya Bill Johnson, Ferit Ucar, Carolyn Miller, Colleen Driscoll, Chisoo Kim, and Lauren Ashcraft. Additional thanks are due to:

- The Grantees and Subgrantees that filled out the program implementation surveys

- The subset of Subgrantees that provided measure installation and utility information

- The utility companies that provided the billing histories

- The residents, weatherization staff and trainees that participated in our surveys

- The survey specialists that patiently worked with all of the above to collect high quality data

- The technicians that worked on the AC study

- The local weatherization program staff and residents that contributed their time to the social networking study

- Staff at the Opportunity Council who helped with the Weatherization Plus Health Study: Debbie Paton, Lorena Shah, and John Davies

Our appreciation is extended to the ORNL, DOE and SMS staff that provided comments on draft versions of this and other ARRA period evaluation reports. Lastly, we thank Jenni Craddick and Meg Eady for handling contracting, finances, and meeting responsibilities and Leslie Lauder and Tracy Clem for their help in preparing the ARRA period reports for publication. 



\section{EXECUTIVE SUMMARY}

In April 2009, the U.S. Department of Energy (DOE) tasked Oak Ridge National Laboratory (ORNL) with conducting an evaluation of DOE's low-income Weatherization Assistance Program (WAP). This directive came at the same time that the American Recovery and Reinvestment Act of 2009 (ARRA) was passed. The Recovery Act boosted WAP's funding from approximately $\$ 230 \mathrm{M}$ per year to $\$ 5 \mathrm{~B}$ over a three-year period. The national weatherization community was expected to be 'shovel ready' to ramp up its production and dramatically increase employment in the field. Also, during this period of time weatherization funding was provided for the first time to five U.S. territories, including Puerto Rico. Because WAP during the Recovery Act period was expected to be so unlike WAP in previous years, the decision was made to evaluate WAP as it was administered both before and during the Recovery Act period. The former is known as the 'retrospective' evaluation of WAP and focuses on Program Year (PY) 2008. 'The latter is known as the 'ARRA period or Recovery Act' evaluation and focuses on PY 2010. This report summarizes findings from the thirteen individual studies that comprise the ARRA period evaluation.

The ARRA period evaluation estimated program impacts (e.g., energy savings), assessed program administration, and conducted several special studies. To accomplish these tasks, the ARRA period evaluation collected a great deal of data, including:

- Housing characteristics and weatherization measures installed in 12,000 single family and mobile homes, 1200 units in small multifamily buildings, and 2700 large multifamily buildings and units in these buildings.

- Fuel type and basic occupant characteristics for 35,000 homes.

- Electricity and natural gas billing histories for $~ 16,000$ weatherized and comparison single family and mobile homes collected from $\sim 400$ natural gas and electric utilities.

- $\quad$ Program implementation survey data from 50+ Grantees and 900 Subgrantees.

- Demographic, energy use behavior, and client satisfaction survey data from 150 treatment households in Puerto Rico.

- Follow-up, post-ARRA demographic and career-related survey data from 500 weatherization auditors, crew leaders, crew members.

- Medicaid records from 49 households (treatment and comparison groups) to estimate the impacts on medical costs of the Opportunity Council's Weatherization Plus Health Program that installed asthma-reduction measures in addition to weatherization measures in homes where children with asthma reside.

- 777 interviews conducted by 74 weatherization recipients and staff from 10 local weatherization agencies to explore potential impacts of shared weatherization experiences on energy-related decisions by those in their social network.

\footnotetext{
${ }^{1}$ Please see Tonn et al. (2014c) for a summary of the retrospective evaluation results.
} 
- Data from eleven homes that were monitored to track cooling-system and whole-house electricity consumption before and after weatherization.

- Electricity use data from 397 refrigerators collected pre-weatherization.

- Information gathered from surveys and interviews with 43 Subgrantees and 119 clients about deferrals of weatherization services.

- $\quad$ Survey data from the directors of $35 \mathrm{DOE}$ weatherization training centers.

In PY 2010, the impact component of the ARRA period evaluation found that:

- WAP funds supported the weatherization of 340,158 units in PY 2010: 65\% single family site built (1-4 units) ${ }^{2}$, 15\% mobile home, and 20\% large multifamily (5+ units).

- DOE expenditures on WAP were $\$ 2,000,000,000$. Including leveraged funding, the total expenditures on units weatherized that included DOE funding were $\$ 2,316,000,000$. The total spent by the national weatherization network in PY 2010 for weatherization was \$2,715,000,000.

- The average cost to weatherize a DOE unit was $\$ 6,812$ (the DOE share for investments in units that received some DOE funding was $87 \%)^{3}$

- $\quad$ WAP and leveraged expenditures supported directly and indirectly 28,000 jobs and increased national economic output by $\$ 4$ billion.

- The estimated first year program energy savings is 7,610,000 Million British Thermal Units (MMBtu). ${ }^{4}$

- Site built homes averaged 26.6 MMBtu of savings in the first year, ${ }^{5}$ mobile homes 16.4 MMBtu, and units in large multifamily homes 15.9 MMBtu.

- The present value of the program energy cost savings using 2013 dollars is $\$ 1,223,000,000$ and the present value per unit weatherized is $\$ 3700$; the estimates using 2010 dollars are $\$ 1,100,000,000$ and $\$ 3,190$.

- Approximately $78 \%$ of these savings accrued to households and $22 \%$ to ratepayers of utilities that have Percentage of Income Payment Programs.

- Carbon emissions were reduced by $7,382,000$ metric tons $^{6}$; criteria pollutants by 17,000 short tons.

- The present value of the environmental emissions benefits for the program is $\$ 645,000,000$, with the present value per weatherized unit is $\$ 1944$; the water savings benefit is $\$ 186$ per unit for a total program benefit of $\$ 49,000,0000$.

\footnotetext{
${ }^{2}$ For the PY 2010 analyses, single-family homes and small multifamily units (1-4 units) have been grouped into a collective category referred to as site built homes.

${ }^{3}$ A DOE unit is defined as any weatherized home that received at least \$1 dollar of DOE funds. The ARRA period evaluation only addressed energy savings in DOE homes.

${ }^{4}$ This is equivalent to nearly 1,340,000 barrels of oil.

${ }^{5}$ For comparison purposes, WAP saved an average of 17.6 MMBtu of energy in site built homes in PY 1989 (Brown et al. 1994).

${ }^{6}$ This is about the amount of carbon emitted by 1,972,000 average automobiles in the US.
} 
- A cluster analysis of weatherized households indicated that $~ 25 \%$ of households coming into the weatherization program suffer an extensive set of household budget problems.

- On balance, households did not change their energy conservation behaviors (e.g., use of appliances) post-weatherization to reduce or increase energy consumption.

- Separate energy education visits to homes were the only aspect of energy education provided to households by Subgrantees that was statistically correlated with changes in energy conservation behavior post-weatherization.

- The present value of a limited set of health and household-related non-energy benefits for the WAP is approximately $\$ 3,830,000,000$; the present value per household (single family and mobile home) is $\$ 14,148$.

- $\quad$ The average electricity savings in homes weatherized by the new Puerto Rico program was 876 kWh per year ( 15\%).

- The social network study found that weatherization clients do share information about their weatherization experiences with members of their social networks and the communications led to actions taken (e.g., 55\% reported changing their energy behaviors, $41 \%$ contacted someone for more information, 28\% completed do-it-yourself (DIY) projects in their own homes).

- Analysis of Medicaid records indicates that the Opportunity Council's Weatherization Plus Health Program reduced the annualized costs associated treating children with asthma by $\$ 421$.

- $\quad$ The average annualized electricity consumption for a refrigerator in the study sample was 756 $\mathrm{kWh} /$ year. The median was $651 \mathrm{kWh} /$ year. The preponderance of the refrigerators' inside temperatures was below the recommended $42{ }^{\circ} \mathrm{F}$.

- The major causes of weatherization services being deferred include worker health and safety, mold and moisture, structural problems, severe water leaks, hoarding, and dangerous pets; $78 \%$ of clients interviewed understood why their homes were deferred, $5 \%$ did not, and $17 \%$ were not aware of or were not informed that the agency deferred services.

- Two years after participating in an initial survey, results of a second survey of weatherization staff indicated that $25 \%$ of auditors, $27 \%$ of crew chiefs, and $40 \%$ of crew members had left the field of low-income weatherization and only $5 \%$ of these individuals remained in the general 'home retrofit' field.

- The number of weatherization training centers expanded appreciably during the ARRA period, though subsequent reductions in funding levels may lead to the closure of a significant number of centers.

During the ARRA period, WAP's funding and production goals were unprecedented. Therefore, the process evaluation component of the evaluation focused on documenting the experiences of the Grantees and Subgrantees during the Recovery Act period. Among the challenges faced by these stakeholders were these:

- Davis-Bacon Act provisions delayed production ramp-up and increased operations and administrative costs for the Subgrantees. 
- Federal and Grantee oversight increased for Subgrantees, which in turn increased administrative costs.

- Both Grantees and Subgrantees had to deal with increased media and political attention focused on their weatherization programs.

- Subgrantees were faced with rapidly increasing and training the new workforce.

- In part, because of these challenges and increased costs, the estimated cost effectiveness of the program during the ARRA period was lower than estimated for the retrospective period.

In many ways, WAP during the Recovery Act resembled WAP as implemented just before the Recovery Act in PY 2008. For example, WAP did not change appreciably during the Recovery Act period with respect to these characteristics:

- Frequency of use of various diagnostic procedures (e.g., blower door tests were used with the same frequency).

- Approaches to and topics covered for client education purposes (e.g., most client education was again delivered during the in-home audit and the most popular topics were thermostat usage, insulation and lighting).

- Approaches for weatherization measure selection (e.g., frequency of Subgrantees using priority lists versus computerized audits was about the same).

- $\quad$ Measures installed (e.g. air sealing was again the most frequently installed measure).

- Use of various training venues (e.g., National Weatherization Program Conference was again a preferred training option).

- Weatherization program marketing efforts were at the local level (e.g., mailings to clients, radio ads were most popular again).

- Leveraged funding was approximately the same (\$700 million in PY 2010 versus $\$ 600$ million in PY 2008) though available leveraged funding per unit was substantially lower.

In some ways, though, WAP as implemented during the Recovery Act was different. For example, the income eligibility requirements were adjusted from being $150 \%$ of the federal poverty level to $200 \%$ and the average amount of DOE funds that could be invested in a home was increased from $\$ 2500$ to $\$ 6500$. In part because of these changes, households that received weatherization services had higher incomes and fewer vulnerable individuals in residence. The formula used to distribute federal weatherization funds to the Grantees was different during the ARRA period in that it allocated a higher percentage of DOE funds to hot climate states. In turn, homes that were weatherized were smaller, newer, less likely to use bulk fuels (e.g., fuel oil), and were more likely to use supplemental fuels (e.g., electric space heaters).

Overall, despite the ramp-up and ramp-down challenges, increased oversight and media attention, and organizational shake-ups experienced within state governments in reaction to ARRA funding increases for low-income weatherization, $44 \%$ of Grantees thought that the added attention to weatherization during the Recovery Act was beneficial, only 12\% disagreed. Amongst Subgrantees, 51\% thought the attention was beneficial, and only 7\% disagreed. Almost half of the Subgrantees thought the public's support for weatherization increased during ARRA; only 3\% thought that support decreased. 


\section{INTRODUCTION}

This report is part of the Recovery Act period national evaluation of the U.S. Department of Energy's (DOE) Weatherization Assistance Program (WAP). The evaluation was managed by Oak Ridge National Laboratory (ORNL) on behalf of DOE. The pages that follow summarize the findings from the thirteen reports that comprise the Recovery Act evaluation.

Briefly, WAP was created by Congress in 1976 under Title IV of the Energy Conservation and Production Act. The purpose and scope of the Program as currently stated in the Code of Federal Regulations (CFR) 10 CFR 440.1 is "to increase the energy efficiency of dwellings owned or occupied by low-income persons, reduce their total residential energy expenditures, and improve their health and safety, especially low-income persons who are particularly vulnerable such as the elderly, persons with disabilities, families with children, high residential energy users, and households with high energy burden.” (Code of Federal Regulations, 2011)

WAP provides grants, guidance, and other support to Grantees: weatherization programs administered by each of the 50 states, the District of Columbia, territories and several Native American tribes. The Grantees, in turn, oversee a network of 900+ local weatherization agencies (Subgrantees): community action agencies, nonprofit organizations, and local government agencies that are eligible to receive weatherization funding from DOE. These weatherization agencies qualify eligible households, assess their homes' energy efficiency opportunities, install energy-saving measures, and inspect the work. The work performed includes air sealing, insulation upgrades, furnace repair/replacements, and other dwelling-specific measures found to be cost-effective, as well as home improvements needed to ensure the health and safety of household occupants. The work is done at no cost to the eligible participants. ${ }^{7}$ WAP weatherizes single-family homes (SF), mobile homes $(\mathrm{MH})$ and multifamily buildings, both small (2-4 units) (SMF) and large (5+ units) (LMF) buildings, regardless of home heating fuel (e.g., natural gas (NG), electricity, fuel oil). WAP procedures are adaptable to all climate zones.

In February 2009, the U.S. Congress passed and the President signed into law the America Recovery and Reinvestment Act (ARRA, also referred to herein as the Recovery Act). Included in the hundreds of billions of dollars of programs, initiatives, and investments was \$5 billion for WAP. The national weatherization network was given approximately three years to spend these funds. Annually, this funding represents about six times more per year than Congress had been typically appropriating for WAP. The huge increase in funding was based on the assumption that weatherization was a 'shovel ready' program, capable of quickly ramping up production and, most importantly given a major goal of ARRA, employing significant numbers of individuals to weatherize low-income homes.

The Recovery Act also included some additional provisions specifically related to WAP:

- The income eligibility threshold for the program was raised from $150 \%$ of the Federal Poverty Level to $200 \%$, though the $60 \%$ or less of the state medium income threshold remained the same;

- The average DOE funding that could be spent per weatherized unit was raised from $\$ 2,500$ to $\$ 6,500$; and

- WAP Grantees and Subgrantees had to adhere to the provisions of the Davis-Bacon Act with respect to prevailing wages and paperwork reporting.

\footnotetext{
${ }^{7}$ To learn more about WAP through a series of case studies, please see Tonn, Rose and Hawkins (2014a).
} 
The first part of this report, Section 2.0, combines an overview of the experiences of the Grantees and Subgrantees during the ARRA period with the impact results to provide an integrated assessment of WAP during this time. The section opens with figures and tables that document weatherization activities during the Recovery Act. Section 2.2 summarizes findings from surveys of Grantees and Subgrantees about their experiences. Section 2.3, 2.4, and 2.5 present the estimated energy savings, non-energy benefits, and costeffectiveness calculations.

The second part of the report, Section 3.0, contains summaries of these eight special studies:

- Weatherization Plus Health - Asthma Study - This study assesses changes in Medicaid costs associated with childhood asthma for homes weatherized by the Opportunity Council's Weatherization Plus Health program in Bellingham, Washington.

- Diffusion of Weatherization-related Information through Social Networks - This study assesses how recipients of weatherization communicated their experiences to individuals in their social networks and whether those communications resulted in additional energy saving actions.

- National Occupant Survey - Additional analyses of the national occupant survey data were undertaken to gain new insights into budget constraints faced by weatherization recipients, changes in energy conservation behaviors post-weatherization, effectiveness of energy education provided by Subgrantees, and use of thermostats.

- Weatherization Deferral - This study assesses deferrals of weatherization services from the viewpoints of 43 Subgrantees and almost 120 households whose weatherization was deferred, while considering deferral rate responses collected through the program implementation surveys administered to 50+ Grantees, 450 Subgrantees, and 350 weatherization auditors.

- $\quad$ U.S. Territories - Funding allocation and weatherization production for five U.S. territories during the Recovery Act period are documented along with energy savings and occupant survey results from Puerto Rico’s program.

- Weatherization Staff, Trainees and Training Centers post-ARRA - Results are presented from three separate reports documenting the status of previously surveyed weatherization staff and individuals who received training at a DOE weatherization training center and plans being undertaken by DOE weatherization training centers post-ARRA.

- Cooling System Consumption and Savings - A pilot study to determine the feasibility and costs associated with monitoring central air conditioning systems pre- and post-weatherization.

- Refrigerator Energy-Use - A small study that analyzed data from monitoring electricity use of refrigerators as part of the retrospective Indoor Environmental Quality study. 


\section{WAP DURING THE RECOVERY ACT PERIOD}

\subsection{PRODUCTION AND EXPENDITURES ${ }^{8}$}

During his first term, President Obama signed ARRA into law in response to the worst economic crisis in the US since the Great Depression. In particular, the Recovery Act targeted 'shovel ready' project (i.e., could ramp-up quickly to support job creation) opportunities to increase employment. Alongside major critical infrastructure projects, the Obama Administration took the opportunity to further its clean energy agenda. The clean energy package in the Recovery Act had four components: efficiency, the Grid, transportation, and clean energy manufacturing and other related projects. ${ }^{9}$ Weatherization was identified as a program that was both shovel-ready and capable of meeting energy efficiency goals. President Obama emphasized the relevance of WAP as providing three major benefits: (1) job creation by increasing the workforce needed to manufacture and sell weatherization materials, to deliver the weatherization service, and to manage its administration; (2) energy conservation and security; and (3) relief for households burdened with higher than necessary home-energy costs. Given this, the decision was made to allocate $\$ 5$ billion of Recovery Act funds to DOE’s Weatherization Assistance Program.

Figures 2.1 to 2.3 depict impacts that the Recovery Act had on WAP. Figure 2.1 tracks DOE WAP expenditures from the beginning of the Recovery Act in April 2009 to when the funds were almost completely exhausted in late 2013. Expenditures peaked at over \$500 million per quarter in Calendar Year (CY) Q1 2011. Weatherization employment supported by ARRA peaked a quarter before that at over 15,000 jobs (see Figure 2.2). Figure 2.3 shows units weatherized peaked in CY Q4 2011 at almost 90,000 units. In comparison, for the entire 2008 Program Year DOE funds supported the weatherization of just under 100,000 units. It should be noted that during the Recovery Act, WAP continued to receive normal program appropriations from Congress. Jobs weatherized utilizing these funds are labeled 'formula units weatherized' in Figure 2.3. Plotting both formula and ARRA period units weatherized indicates how much production ramped-up during the ARRA period. Additionally, the plots indicate that formula units weatherized as of CY Q1 2014 were substantially below the formula units weatherized preARRA. ${ }^{10}$

\footnotetext{
${ }^{8}$ Much of the text in this and the next subsections are drawn from Tonn, Rose and Hawkins (2015b).

${ }^{9}$ Aldy, J. 2011. A Preliminary Review of the American Recovery Act’s Clean Energy Package. RWP11-048, Kennedy School of Government, Harvard University, Cambridge, MA, December.

${ }^{10}$ This lack of production is due to sharp reductions in Congressional appropriations for WAP. This has left many Grantees and Subgrantees scrambling to keep their programs in operation. As an example is testimony to the Vermont Senate and Welfare Committee by the state's weatherization program for funding to prevent the mothballing of weatherization equipment purchased during the Recovery Act period and to keep weatherization waiting lists from exceeding a year. Shollenberger, A. 2014 http://www2.leg.state.vt.us/CommitteeDocs/2014/Senate\%20Health\%20and\%20Welfare/Budget\%20Discussion/W Amy\%20Sh ollenberger Weatherization\%20Assistance\%20Program\%20Written\%20Testimony 4-16-2014.pdf
} 


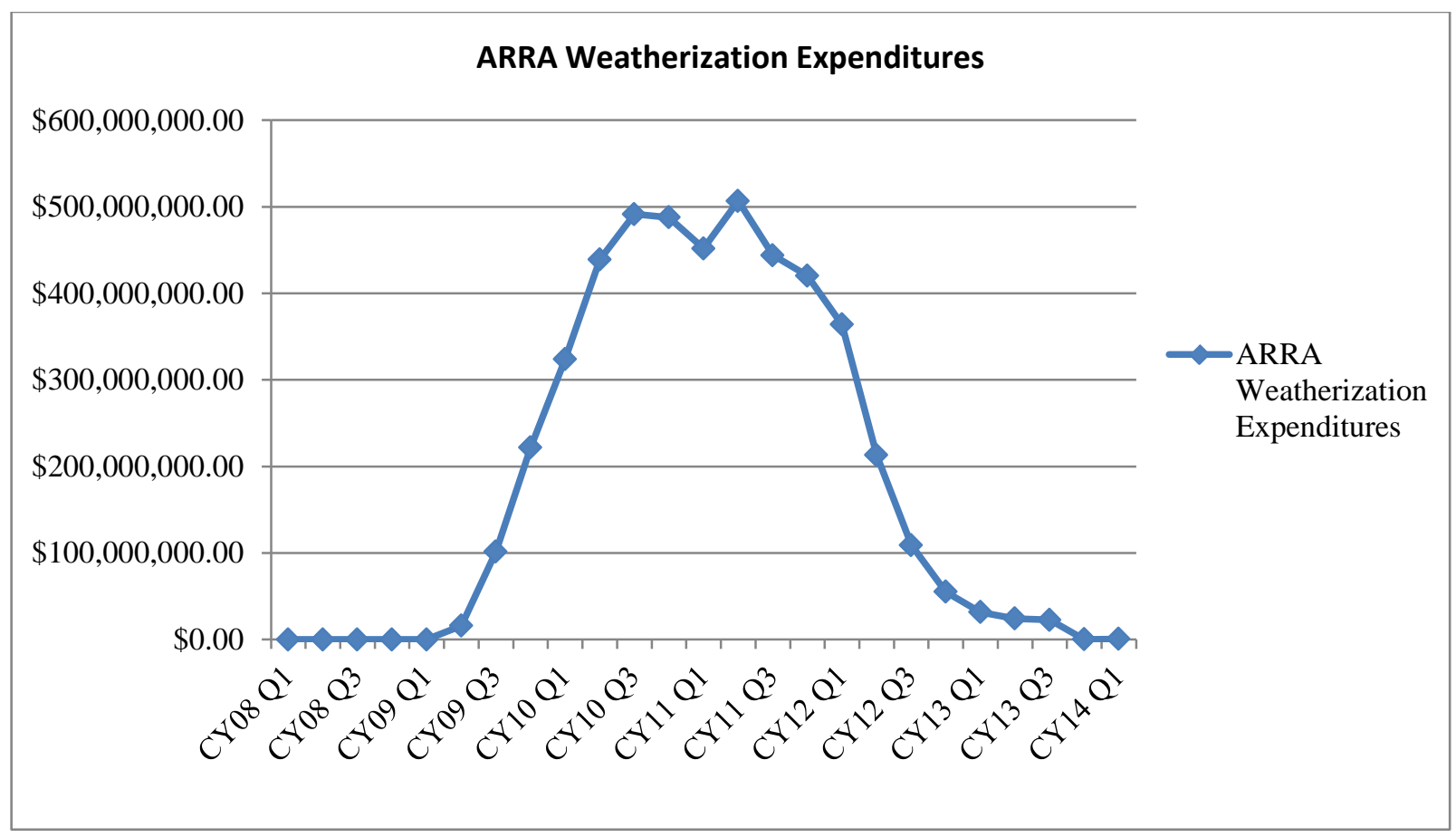

Figure 2.1 DOE WAP Expenditures during the Recovery Act Period

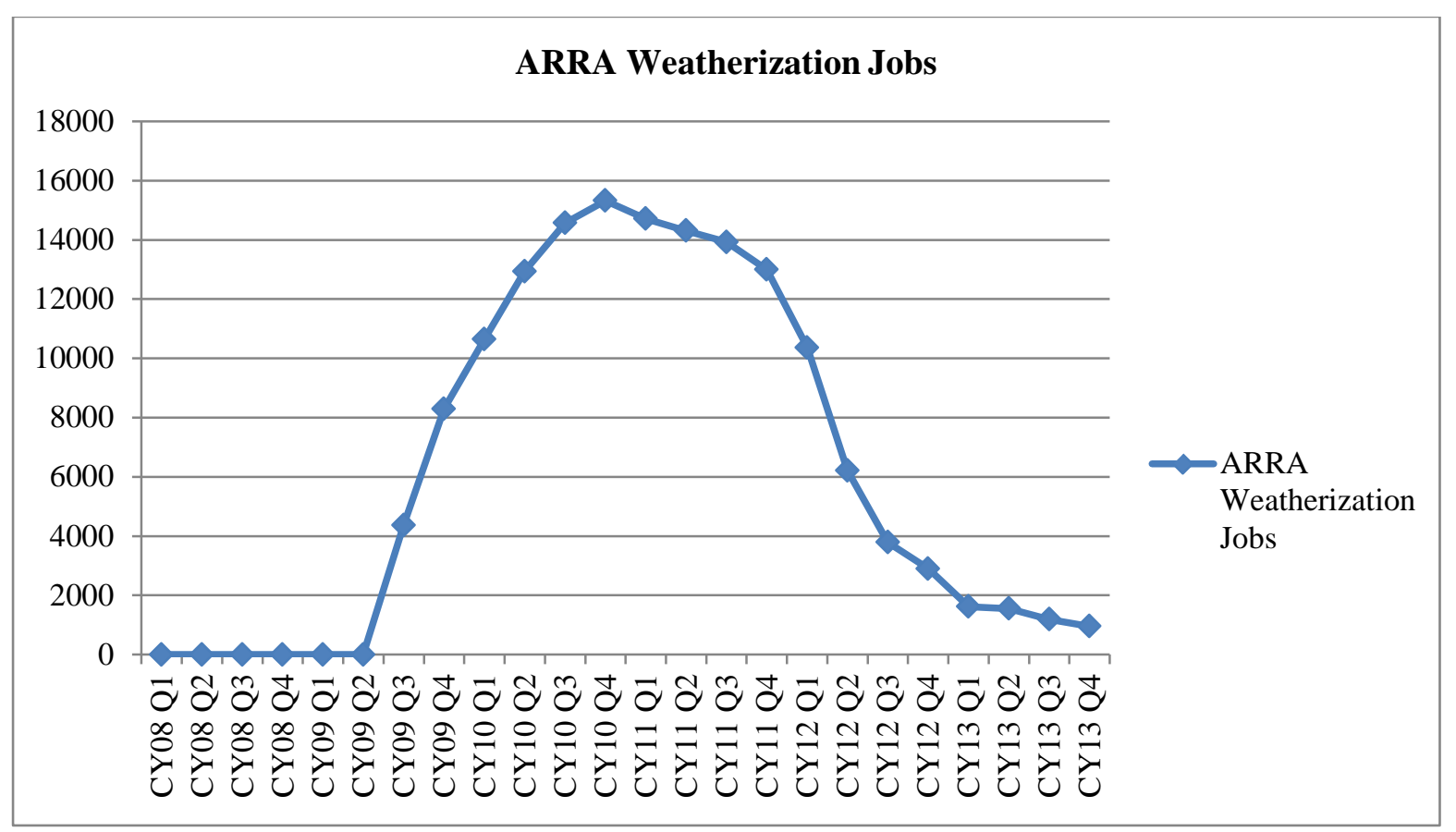

Figure 2.2 Weatherization Employment Supported by Recovery Act Funds 


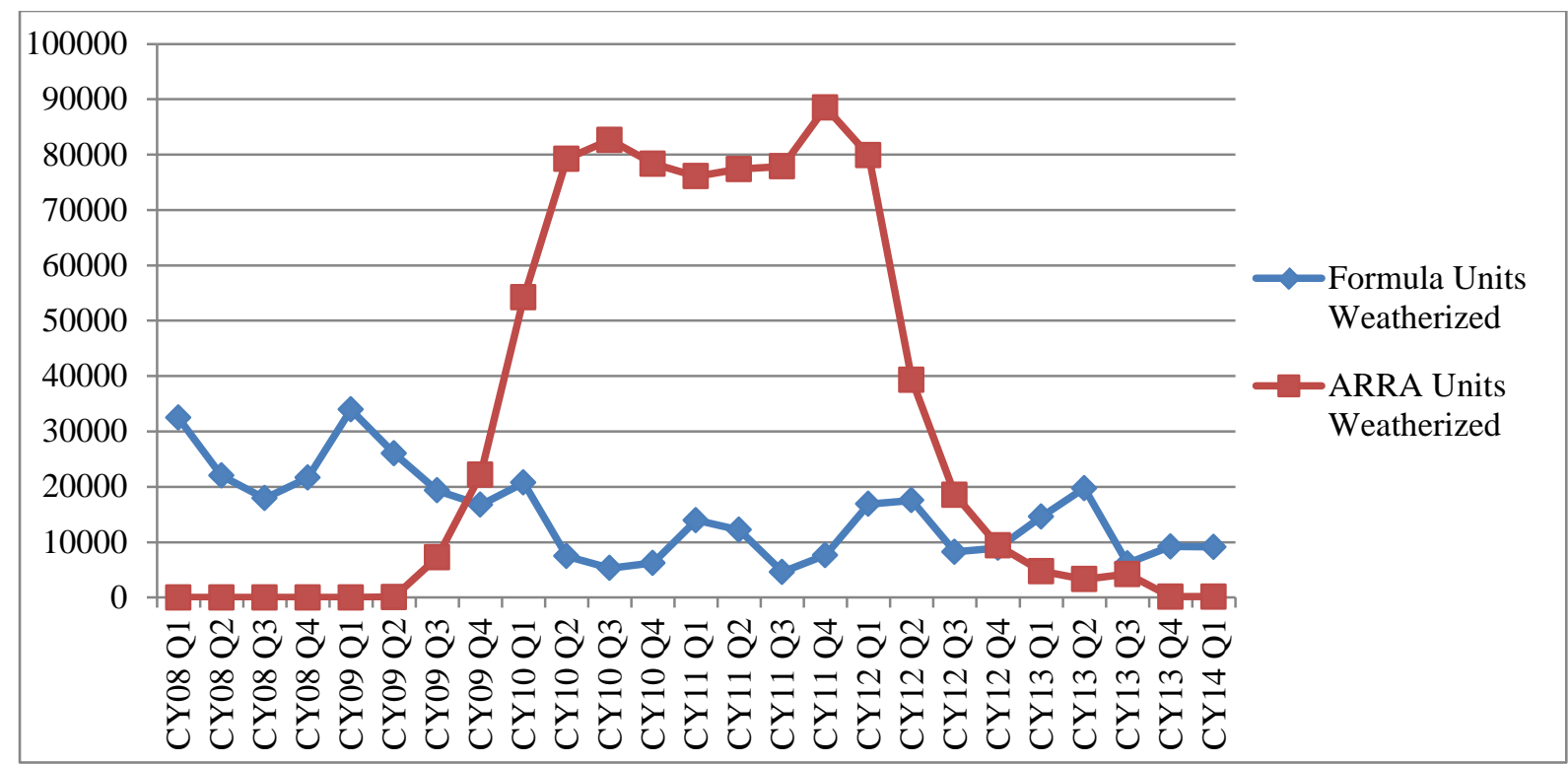

Figure 2.3 Units Weatherized Using ARRA and Normal Appropriations (Formula) Funding

Tables 2.1 and 2.2 present units weatherized by housing type and climate zone (see Figure 2.4), respectively, for the year before the Recovery Act (PY 2008) and for one year during the Recovery Act (PY 2010). The program's character, that of focusing predominately on single family (SF), small multifamily (SMF), and mobile homes (MH), did not change appreciably during the Recovery Act, though the share of weatherized units being in large multifamily (LMF) buildings increased somewhat. However, the proportion of homes weatherized shifted from the cold regions to the hot regions, which has implications for the national average of energy savings per weatherized homes.

Table 2.1 Weatherized Units in Program Years 2008 and 2010 by Housing Type

\begin{tabular}{|lllll|}
\hline Housing Type & 2008 Units & 2008 by $\%$ & 2010 Units & 2010 by \% \\
\hline Site Built Homes (1-4 units) & 62,835 & $64 \%$ & 215,445 & $65 \%$ \\
\hline Mobile Homes & 17,754 & $18 \%$ & 48,267 & $14.5 \%$ \\
\hline Large Multi-family Units (5+) & 17,376 & $18 \%$ & $68,153^{11}$ & $20.5 \%$ \\
\hline Total & $\mathbf{9 7 , 9 6 5}$ & $\mathbf{1 0 0 \%}$ & $\mathbf{3 3 1 , 8 6 5}$ & $\mathbf{1 0 0 \%}$ \\
\hline
\end{tabular}

Table 2.3 provides a summary of the measures installed by WAP during PY 2010. Similar to PY 2008, the most frequently installed measures in SF and $\mathrm{MH}$ were related to air sealing, followed by attic insulation, duct sealing and heating system measures. The table indicates that measures typically installed in SF homes are observably different than those installed in other housing types. For example, attic and wall insulation have higher installation rates in SF homes. On the other hand, floor insulation is more frequently installed in $\mathrm{MH}$ and air conditioning measures more so in both small and large MF buildings. Windows were installed in less than a quarter of the units, but in most instances their installation was supported by favorable savings-to-investment ratios (SIR). New heating and water heating systems were

\footnotetext{
${ }^{11}$ This number excludes a small number of large multifamily units that no information was collected about and also weatherized shelters. For completeness, the total number of weatherized units is 340,158.
} 
less frequently installed as energy conservation measures (ECM), but more frequently installed as nonECMs (i.e., health and safety). Interestingly, almost all new air conditioners passed the SIR test. ${ }^{12}$

Table 2.2 Weatherized Units in Program Years 2008 and 2010 by Climate Zone

\begin{tabular}{|lcccc|} 
Climate Zone & 2008 Units & 2008 by $\%$ & 2010 Units & 2010 by \% \\
\hline Very Cold & 24,749 & $25 \%$ & 58,584 & $18 \%$ \\
\hline Cold & 42,233 & $43 \%$ & 127,386 & $38 \%$ \\
\hline Moderate & 18,794 & $19 \%$ & 56,006 & $17 \%$ \\
\hline Hot/Humid & 6,390 & $7 \%$ & 55,157 & $17 \%$ \\
\hline Hot/Dry & 5,799 & $6 \%$ & 34,732 & $10 \%$ \\
\hline Total & $\mathbf{9 7 , 9 6 5}$ & $\mathbf{1 0 0} \%$ & $\mathbf{3 3 1 , 8 6 5}$ & $\mathbf{1 0 0} \%$ \\
\hline
\end{tabular}

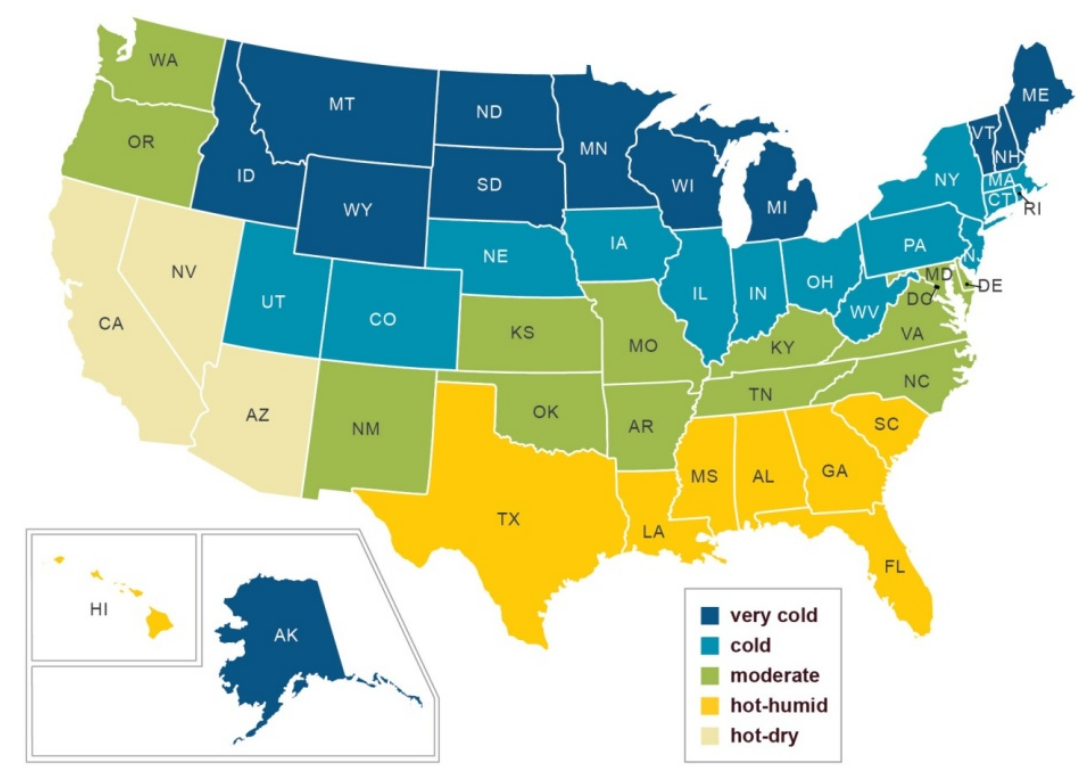

Figure 2.4 Climate Zones

Table 2.4 indicates that the number of major measures (e.g., air sealing, insulation, furnace replacement) installed in SF homes stayed about the same from PY 2008 to PY 2010, which has the effect of incrementally reducing the total energy savings potential of the weatherization packages installed in SF homes (see Table 2.5). The number of $\mathrm{MH}$ that received 4 or more major measures dropped to less than $10 \%$, but the number of $\mathrm{MH}$ that received 3 major measures increased from $16 \%$ to $21 \%$, which may have offset each other with respect to energy savings (see Table 2.4).

\footnotetext{
12 The savings to investment ratio is calculated by dividing the estimated lifetime energy costs savings for a measure by its installation cost.
} 
Table 2.3. PY 2010 Measures by Building Type

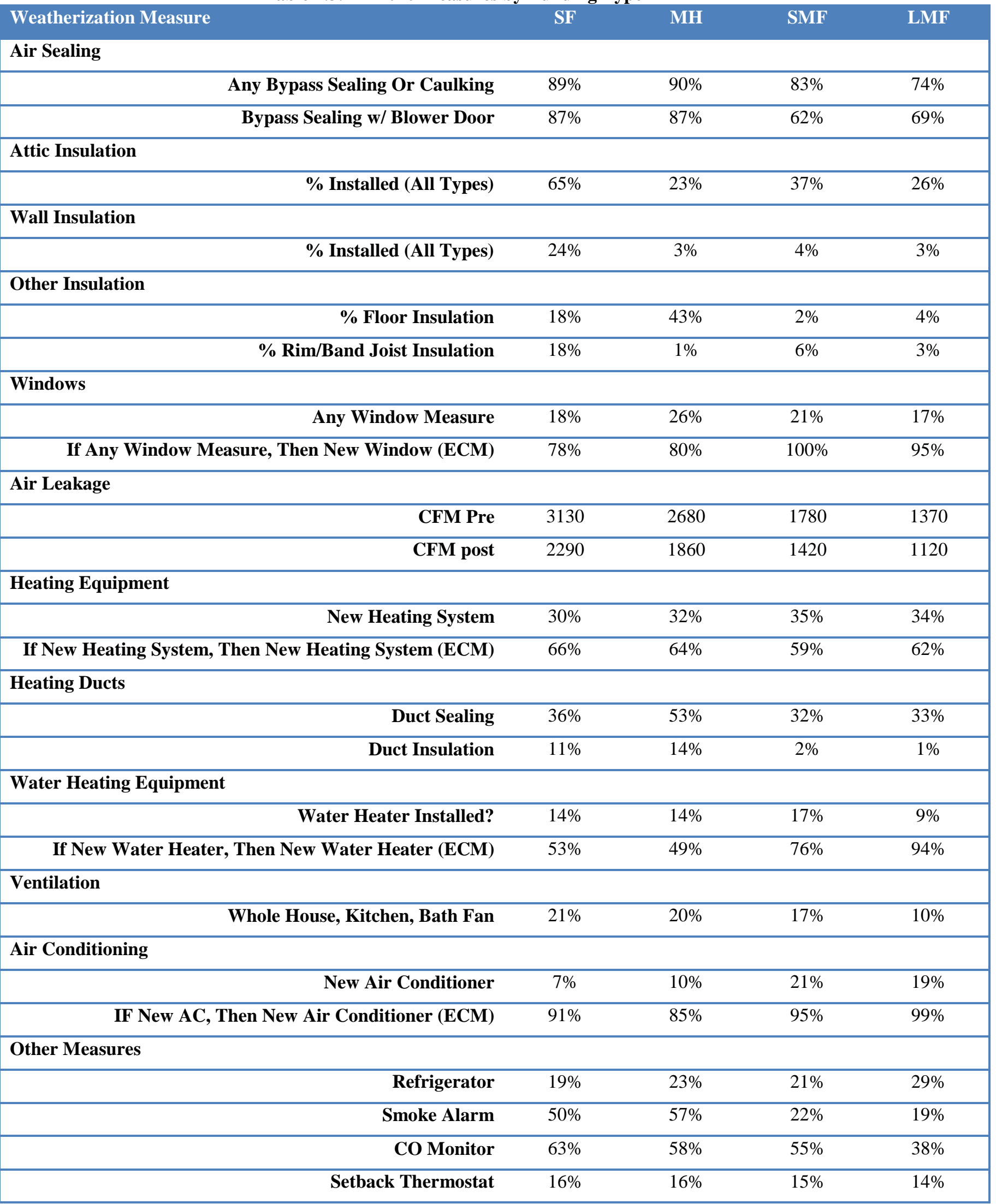


Table 2.4 Major Measures Installed Single Family and Mobile Homes

\begin{tabular}{|ccccc|}
\hline Number of Major Measures & \multicolumn{2}{c}{ Single Family } & \multicolumn{2}{c|}{ Mobile Homes } \\
\hline & $\mathbf{2 0 0 8}$ & $\mathbf{2 0 1 0}$ & $\mathbf{2 0 0 8}$ & $\mathbf{2 0 1 0}$ \\
\hline $\mathbf{4}^{+}$ & $6 \%$ & $5 \%$ & $11 \%$ & $7 \%$ \\
\hline $\mathbf{3}$ & $20 \%$ & $18 \%$ & $16 \%$ & $21 \%$ \\
\hline $\mathbf{2}$ & $31 \%$ & $33 \%$ & $30 \%$ & $32 \%$ \\
\hline $\mathbf{1}$ & $32 \%$ & $31 \%$ & $29 \%$ & $27 \%$ \\
\hline $\mathbf{0}$ & $11 \%$ & $12 \%$ & $14 \%$ & $13 \%$ \\
\hline
\end{tabular}

DOE allows Grantees and Subgrantees to leverage their DOE funding to acquire additional funding for low-income weatherization. Table 2.5 presents the DOE funding and leveraged funding received by Grantees and Subgrantees in PY 2010 and PY 2008. In both years, the largest source of leveraged funding was the allocation of federal Low Income Home Energy Assistance Program (LIHEAP) funds received by states to their state weatherization programs. State public benefit programs, other state programs, and utilities provided the bulk of the remaining leveraged funding. Leveraged funding stays about the same between 2008 and 2010, while the DOE funding increased substantially.

Table 2.5 DOE and Leveraged Weatherization Funding in PY 2010 and PY 2008 (\$ millions)

\begin{tabular}{|c|c|c|c|c|c|c|c|c|}
\hline & \multicolumn{4}{|c|}{2010} & \multicolumn{4}{|c|}{2008} \\
\hline & \multicolumn{2}{|c|}{ Grantees } & \multicolumn{2}{|c|}{ Sub-grantees } & \multicolumn{2}{|c|}{ Grantees } & \multicolumn{2}{|c|}{ Sub-grantees } \\
\hline & $\mathrm{N}$ & $\$$ & $\mathrm{~N}$ & $\$$ & $\mathrm{~N}$ & $\$$ & $\mathrm{~N}$ & $\$$ \\
\hline DOE & 51 & $\$ 2,008$ & - & - & 51 & $\$ 236$ & - & - \\
\hline LIHEAP & 43 & $\$ 401$ & 5 & $\$ 1$ & 46 & $\$ 319$ & 11 & $\$ 3$ \\
\hline State Public Benefit & 5 & $\$ 46$ & 52 & $\$ 19$ & 8 & $\$ 83$ & 50 & $\$ 9$ \\
\hline Other State Programs & 6 & $\$ 37$ & 104 & $\$ 21$ & 10 & $\$ 31$ & 145 & $\$ 27$ \\
\hline Utilities & 13 & $\$ 24$ & 268 & $\$ 94$ & 14 & $\$ 21$ & 174 & $\$ 52$ \\
\hline PVE and Other Fed. Programs & 8 & $\$ 10$ & 78 & $\$ 17$ & 9 & $\$ 12$ & 90 & $\$ 30$ \\
\hline $\begin{array}{l}\text { Program Income, In-kind, Non- } \\
\text { profit, } 3^{\text {rd }} \text { Party, Other }\end{array}$ & 3 & $\$ 22$ & 171 & $\$ 14$ & 4 & $\$ 20$ & 106 & $\$ 6$ \\
\hline Total & & $\$ 2,548$ & & $\$ 167$ & & $\$ 722$ & & $\$ 128$ \\
\hline State Retained & & $\$ 138$ & & & & $\$ 50$ & & \\
\hline Pass Through to Subgrantees & & $\$ 2,409$ & & & & $\$ 672$ & & \\
\hline Total Program Funding & & $\$ 2,715$ & & & & $\$ 850$ & & \\
\hline Amount Spent on DOE units & & $\$ 2,316$ & & & & $\$ 460$ & & \\
\hline Number of DOE units & & 340,158 & & & & 97,965 & & \\
\hline
\end{tabular}

Figure 2.5 illustrates the impact of ARRA funding on the Subgrantees. The Subgrantees were clustered into four groups based on funding levels and sources of funding. The clusters with the highest number of 
Subgrantees were clusters \#4 in years PY 2008 and PY 2010, which are characterized by relatively small funding levels. However, the average level of funding increased by approximately $\$ 900,000$. In PY 2008 , one of the clusters of Subgrantees, \#1, was funded primarly by DOE funds, whereas clusters \#2 and \#3 were funded primarly by other leveraged dollars (e.g., state benefit funds, utilities) and LIHEAP, respectively. In PY 2010, every cluster of Subgrantees was funded primarily by DOE dollars. Total funding for the Subgrantees with the largest programs increased by approximately $\$ 3.5$ million dollars.

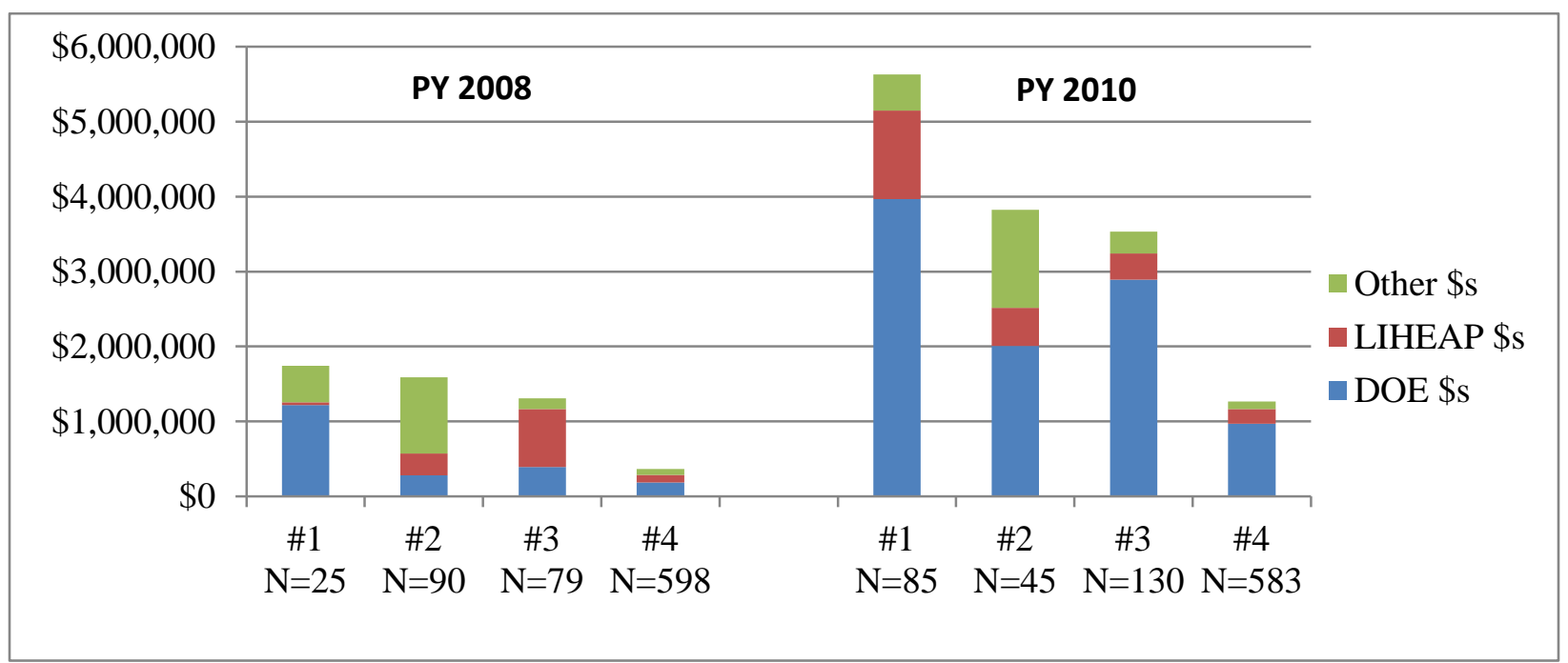

Figure 2.5 Clusters 20 forbgrantees by Funding Levels and Source PY 2008 and PY 2010

\subsection{THE RECOVERY ACT EXPERIENCE ${ }^{13}$}

The substantial funding increase created a number of issues for the national weatherization network. Surveys completed by the Grantees and Subgrantees indicated that because of ARRA:

- The political visibility of their programs increased significantly

- It was common for organizational responsibilities for WAP to shift at the state level

- New state laws and regulations were passed that impacted their programs

- Media attention of their programs increased

- Federal oversight of their programs increased

The increased oversight increased administrative costs. Also causing an increase in costs was the stipulation in the Recovery Act that WAP fall under the provisions of the Davis-Bacon Act of 1931. This Act requires that all federal construction and public works projects need to pay 'prevailing wages' for laborers and mechanics. Production ramp up was delayed in the majority of states for almost six months while the U.S. Department of Labor determined what the prevailing wages would be county-by-county for weatherization-related jobs. Administrative costs were increased because of weekly time keeping paperwork requirements. Job costs were increased because in some instances the prevailing wages were higher for some types of skills and some types of buildings than wages previously paid by the Subgrantees. Overall, 94\% of Grantees and 80\% of Subgrantees reported that Davis-Bacon increased their costs.

\footnotetext{
${ }^{13}$ Material presented in this subsection is taken primarily from Tonn, Rose and Hawkins (2015b).
} 
In many ways WAP as implemented during ARRA was very similar to the program pre-ARRA. For example, comparing results of surveys administered to Grantees and Subgrantees that addressed PY 2008 to survey results related to PY 2010, these program aspects were very similar in:

- Frequency of use of various diagnostic procedures (e.g., blower door tests)

- Approaches to and topics covered for client education purposes (e.g., most client education was delivered during the in-home audit and the most popular topics were thermostat usage, insulation and lighting)

- Approaches for weatherization measure selection (e.g., priority lists versus computerized audits)

- Measures installed (e.g., again air sealing measures were the most frequently installed)

- $\quad$ Use of various training venues (e.g., National Weatherization Program Conference)

- Weatherization program marketing occurred at the local level (e.g., mailings to clients, radio ads)

- Having long waiting lists

The influx of ARRA funds changed how the program operated at the margin. For example, Subgrantees were able to purchase new diagnostic tools, which led to small increases in the use of infrared scanners to examine insulation levels. Two-thirds of Subgrantees observed some economies of scale as their programs increased. It should also be mentioned that because of the increased number of new workers, the overall level of experience of the weatherization workforce decreased. Additionally, it was found that the rate that homes were deferred for weatherization increased somewhat. ${ }^{14}$

The demographic and housing characteristics of the WAP recipients in PY 2010 differed somewhat from the PY 2008 recipients. For example, the households and homes weatherized in PY 2010:

- $\quad$ Had higher incomes - e.g., average annual household income for those living in SF homes in PY 2010 was \$15,700 versus \$13,200 in PY 2008 and for MH was \$13,400 in PY 2010 versus $\$ 11,470$ in PY 2008

- $\quad$ Had fewer vulnerable individuals - e.g., the percent of SF homes with a person with disabilities was 30\% in PY 2010 versus 39\% in PY 2008 and for MH was 39\% versus 49\%

- Were more likely to be non-white - the percentage of Black and Hispanic households living in SF and MH served increased (e.g., from 31\% in PY 2008 to 39\% in PY 2010 for SF homes and 15\% to $22 \%$ for $\mathrm{MH}$ )

- $\quad$ Were smaller in size, on average - e.g., the average size of SMF unit in PY 2010 was $800 \mathrm{ft}^{2}$ versus 1,054 $\mathrm{ft}^{2}$ in PY 2008

- Were newer - e.g., the percent of SF, SMF and LMF built 1970 or later increased from 26\% to 33\%, 35\% to 82\% and 49\% to 79\%, respectively, from PY 2008 to PY 2010.

\footnotetext{
${ }^{14}$ See Rose et al. (2015b).
} 
- Were less likely to use bulk fuels - the percent of weatherized SF, MF, SMF and LMF using fuel oil dropped from $14 \%$ to $5 \%, 10 \%$ to $5 \%, 10 \%$ to $3 \%$, and $17 \%$ to $4 \%$, respectively from PY 2008 to PY 2010.

- $\quad$ Were more likely to use supplemental fuels - e.g., 15\% of SF homes used electricity for supplemental heat in PY 2010 versus 9\% in PY 2008.

Many of these differences can be attributed to the higher proportion of homes weatherized in the hot climates and an increase of the income eligibility threshold to $200 \%$ of the federal poverty level.

There was some concern within the national weatherization network that the influx of ARRA funds would permanently damage leveraging relationships. As stated, DOE allows the Grantees and Subgrantees to use some DOE funding and the weatherization programs established with WAP funding to leverage additional funding for low-income weatherization. For example, in PY 2008, DOE provided \$236 million in funding that was leveraged to obtain over \$600 million in additional funding. In PY 2010, DOE funding was $\$ 2$ billion and leveraged funding was just over \$700 million. Both Grantees and Subgrantees reported that some leveraged relationships were indeed damaged, a few permanently. This is an important issue because, in many instances, over a decade of effort was needed to secure the leveraging relationships. However, two-thirds of Grantees and over $40 \%$ of Subgrantees stated that they believe that the long-term impacts of ARRA on leveraging relationships will be positive, versus only $12 \%$ and $14 \%$ of Grantees and Subgrantees, respectively, believing otherwise.

Despite all of the stresses involved with the Recovery Act and issues surrounding media coverage, $44 \%$ of Grantees thought that the added attention to weatherization during the Recovery Act was beneficial and only 12\% disagreed. Amongst Subgrantees, 51\% thought the attention was beneficial, and only 7\% disagreed. Almost half of the Subgrantees thought the public's support for weatherization increased; only $3 \%$ thought that support decreased. These beliefs undoubtedly underlie the mostly positive outlook that the respondents have with respect to the future of their leveraged funding.

Before discussing the program's energy savings estimates, it is important to first summarize factors encountered by the national weatherization network during the ARRA period that could have led to changes in energy impacts observed during the retrospective evaluation:

- An inexperienced weatherization workforce may have missed some energy savings opportunities.

- More units were weatherized in hot climates where per unit energy savings are generally lower.

- Increased costs reduced the number of measures that could pass SIR test and may have reduced the number of measures installed per home.

- The average number of major measures installed per unit was lower in the ARRA period than in the retrospective, thereby reducing average energy savings.

- Increased oversight in some cases may have increased work quality, which in turn, may have increased energy savings. 
Additionally, one could argue that many factors impacted cost effectiveness of the national WAP, including:

- Davis Bacon increased weatherization costs through increases in wages for weatherization staff and administrative costs for manpower for to handle the extra paperwork.

- Increased oversight increased administrative costs.

- Drags on administration efficiency caused by bureaucratic reorganization, organizational attention to ramp-up and ramp-down processes, and media and political scrutiny.

- Efficiencies created by economies of scale attributable to larger Subgrantee programs.

\subsection{ENERGY SAVINGS ESTIMATES ${ }^{15}$}

Similar to the methodology used to estimate energy savings for the retrospective evaluation, a subset of 450 Subgrantees were selected to provide NG and/or electric utility account information for the units they weatherized in PY 2010 and PY 2011. Units for energy analyses of SF and MH, approximately one-third from each list submitted by a Subgrantee, were randomly selected to be in the sample. The evaluation team then contacted the requisite NG and electric utilities to collect the billing histories. Bills were collected for periods of 12 months pre-weatherization and 12 months post-weatherization. Homes weatherized in PY 2011 were used as a comparison group for the treatment group homes weatherized in PY 2010. For the PY 2010 analyses, the SMF units have been grouped with the SF homes into a site built homes (1-4 units) category. This was done because from a building science perspective, the units in SMF buildings behave and respond to weatherization in the same manner as SF homes.

Table 2.6 presents the aggregate and per unit energy savings estimates by house type for PYs 2008 and 2010. One can see that the substantial increase in the number of units weatherized more than tripled the total energy savings achieved in the site built home sector. On the other hand, for many of the reasons cited above, the energy savings per unit decreased somewhat from 2008 to 2010 in the site built category, from 29.3 MMBtu to 26.6 MMBtu. The unit savings for the MH category increased somewhat during the ARRA period. The LMF savings per unit dropped when buildings outside of New York City were added to the sample. For comparison purposes, the per unit energy savings for weatherized site built homes in PY 1989 was 17.6 MMBtu (Brown et al. 1994).

\footnotetext{
15 The PY 2010 and PY 2008 energy savings, energy cost savings, and energy cost-effectiveness estimates presented in the balance of Section 2.0 are drawn from Blasnik et al. (2015a, 2015b) and Carroll et al. (2015a) and Blasnik et al. (2014a, 2014b, 2014c, and 2014d) respectively.
} 
Table 2.6 Estimated Energy Savings by House Type for PY 2008 and 2010

\begin{tabular}{|lcccc|}
\hline $\begin{array}{l}\text { Program } \\
\text { Year/Home Type }\end{array}$ & 2008 & 2008 & 2010 & 2010 \\
\hline $\begin{array}{c}\text { Total MMBtu } \\
\text { Saved }\end{array}$ & $\begin{array}{c}\text { MMBtu/ Unit } \\
\text { Saved }\end{array}$ & $\begin{array}{c}\text { Total MMBtu } \\
\text { Saved }\end{array}$ & $\begin{array}{c}\text { MMBtu/ Unit } \\
\text { Saved }\end{array}$ \\
\hline $\begin{array}{l}\text { Site Built Homes } \\
\mathbf{( 1 - 4} \text { units) }\end{array}$ & $1,8400,000$ & 29.3 & $5,730,000$ & 26.6 \\
\hline Mobile Homes & 284,000 & 16.0 & 790,000 & 16.4 \\
\hline $\begin{array}{l}\text { Large Multi- } \\
\text { family }\end{array}$ & 144,000 & 26.9 & $1,086,554$ & \\
\hline Total & NYC LMF) & & $7,609,628$ & \\
\hline
\end{tabular}

Figure 2.6 presents the estimated energy savings for site built homes for five program years, 2007 to 2011 by climate zone. The first panel presents NG savings for homes heated with NG. The second panel presents estimated electricity savings for those homes. The third panel presents electricity savings in homes heated by electricity. Estimated energy savings were only done nationally for PYs 2007, 2009, and 2011. Net energy savings are presented for every year except the last, PY 2011, which are gross energy savings.

Overall, the results meet expectations. The percentage of energy savings is higher for NG in NG heated homes than for electricity in homes heated with electricity. Baseload electricity savings are lower than NG savings as a percentage in homes heated with NG. NG savings are quite a bit lower in homes located in the hot-dry climate zone. Energy savings are higher in the cold climate zone than in the very cold climate zone for homes heated with NG. The national averages for energy savings in the three panels cluster around $17 \%, 7.5 \%$, and $10.5 \%$, respectively.

On the other hand, the national averages and estimated savings by climate zone do vary across the five years, even taking into account the comparison groups to estimate net energy savings. For example, as hypothesized in the previous section, energy savings in site built homes dropped from 2008 to 2010, possibly due to many factors associated with the Recovery Act period. But then again, the savings rebounded in PY 2011, possibly due to the national weatherization network meeting the challenges of the Recovery Act period. Additionally, electricity saved in homes heated with NG and homes heated with electricity were higher in the Recovery Act years than in PY 2008. 


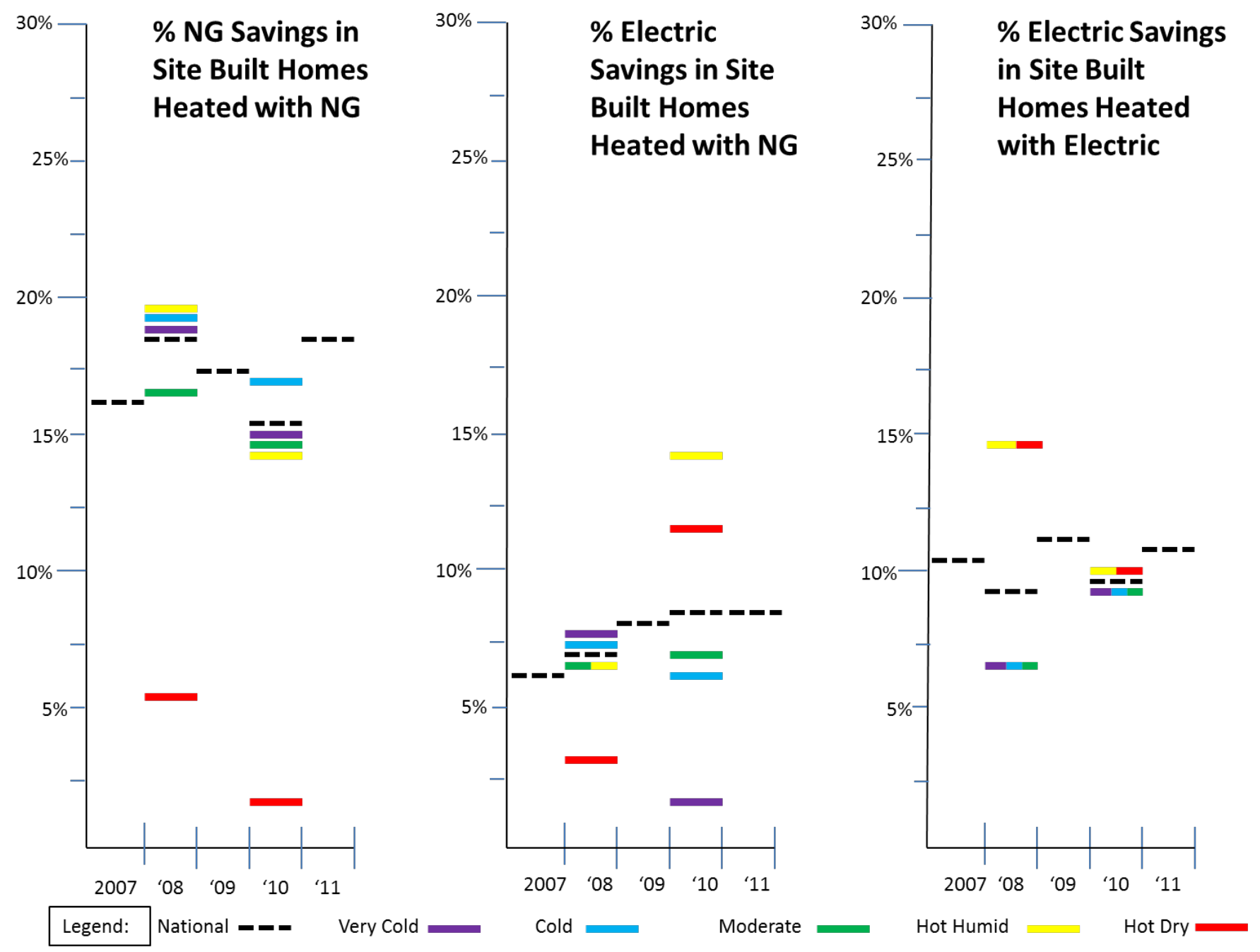

Figure 2.6 Estimated Energy Savings in Site Built Homes PY 2007 to 2011 by Climate Zone

Figure 2.7 presents the same sets of results as Figure 2.6 but for MH. As expected, on average, the NG savings in MH heated with NG are less than NG savings in site built homes. The pattern of energy savings also holds across the three panels: NG savings are higher than baseload savings in homes heated with NG and generally higher than electricity savings in homes heated with electricity, though the latter relationships does not hold for all five years. The variation in NG savings averages is higher for MH than for site built homes. From the variation and patterns, it is not possible to detect an impact of the Recovery Act on energy savings. The relationships with climate zone are also more varied, especially between the cold and very cold climates. 


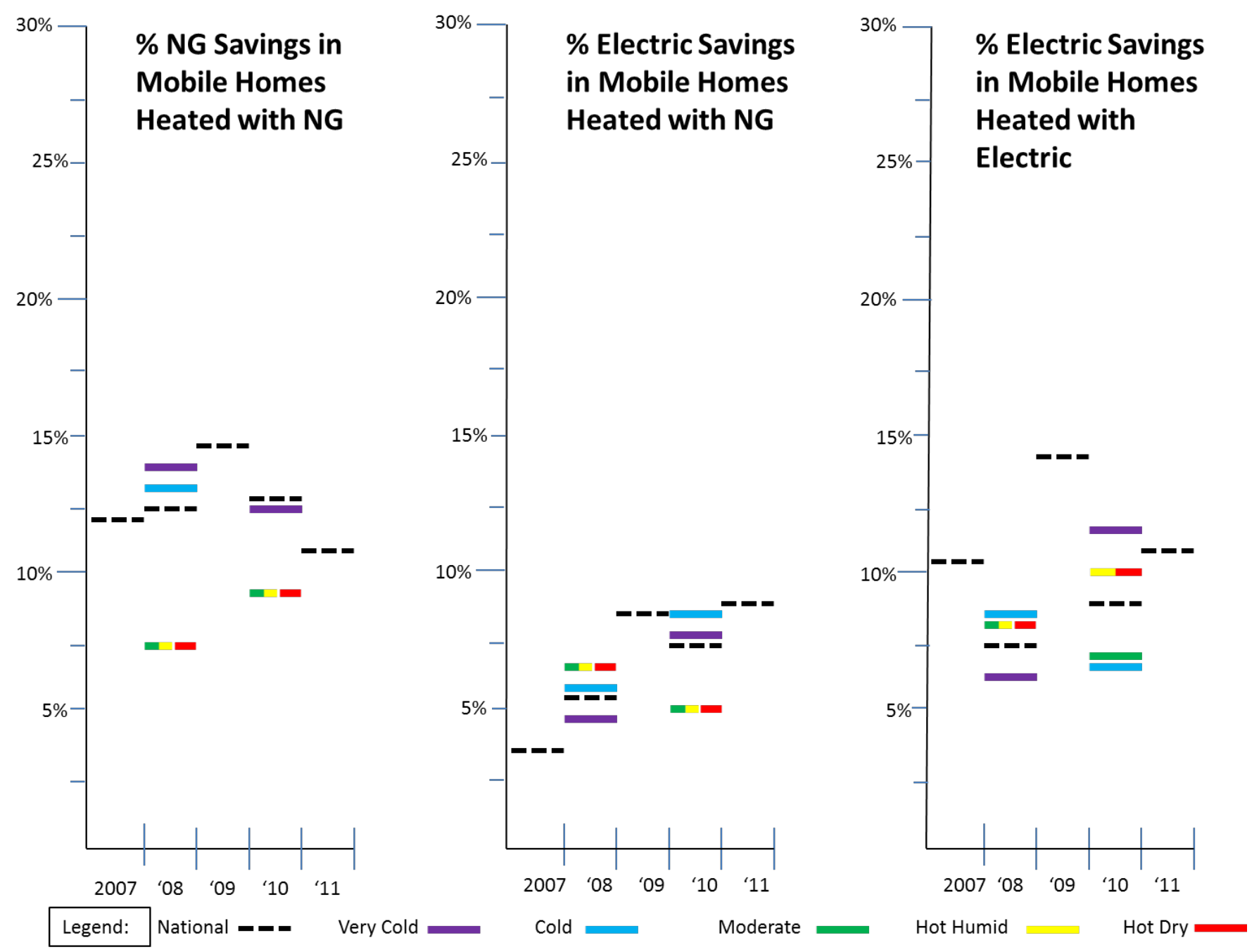

Figure 2.7 Estimated Energy Savings in Mobile Homes PY 2007 to 2011 by Climate Zone

Table 2.7 presents energy savings estimates for LMF buildings weatherized in the PY 2008 and PY 2010 periods. The PY 2008 results are drawn from analyses of billing histories collected for LMF buildings weatherized in New York City (NYC) whereas the PY 2010 savings estimates are based on billing histories for LMF buildings weatherized nationwide. The savings estimates for the PY 2010 LMF buildings are quite similar to the per unit energy savings estimates for SF and MH. The most significant difference between the PY 2010 energy savings estimates and the PY 2008 estimates is in the electricity savings for LMF buildings heated with NG or FO. The savings in the PY 2008 buildings is much higher because the LMF buildings in NYC were targeted for ECMs as they consume a good deal of electricity in common spaces, which are less common in LMF buildings across the country. 
Table 2.7 Large Multifamily Building Energy Savings (per unit)

\begin{tabular}{|lcccc|} 
& PY 2008 Savings* & PY 2010 \\
\hline & Gross & \% & Gross & \% \\
\hline $\begin{array}{l}\text { Heating Fuel Savings (NG \& Fuel Oil heated buildings) } \\
\text { therms }\end{array}$ & 90.5 & $18 \%$ & 99 & $14.2 \%$ \\
\hline $\begin{array}{l}\text { Electricity Savings (NG \& Fuel Oil heated buildings) } \\
\text { kWh }\end{array}$ & 578 & $18.3 \%$ & 304 & $6.4 \%$ \\
\hline $\begin{array}{l}\text { Electricity Savings (Electric heated buildings) } \\
\text { kWh }\end{array}$ & -- & -- & 810 & $10.9 \%$ \\
\hline
\end{tabular}

\subsection{ENERGY COST SAVINGS ESTIMATES}

Table 2.8 presents estimates present value of the energy cost savings by housing type by program year. The SF and SMF estimates have been combined in PY 2008 for this analysis and as mentioned previously are referred to collectively as site-built homes. The decrease in dollars saved per site built homes from PY 2008 to PY 2010 is expected given the factors identified above in Section 2.2. The dollars saved per MH weatherized did not change appreciably from one period to the next. The large decrease in the average energy costs savings per unit in the LMF sector is explainable: a very large percentage of weatherized LMF buildings in New York City use very expensive fuel oil for their heating fuel. This expensive energy source is rarely used outside of the Northeast.

Table 2.8 Summary of Energy Cost Savings by House Type and Program Year (Present Value)

\begin{tabular}{|c|c|c|c|c|}
\hline & 2008 & 2008 & 2010 & 2010 \\
\hline & Total \$ Saved & \$ Saved/ Unit & Total \$ Saved & \$ Saved/ Unit \\
\hline Site Built (1-4 units) & $\$ 331,300,000$ & $\$ 5,200$ & $\$ 963,000,000$ & $\$ 4,468$ \\
\hline Mobile Homes & $\$ 54,200,000$ & $\$ 3,053$ & $\$ 143,000,000$ & $\$ 2,957$ \\
\hline Large Multifamily & $\begin{array}{l}\$ 34,500,000 \\
\text { (NYC LMF) }\end{array}$ & $\begin{array}{c}\$ 6,460 \\
\text { (NYC LMF) }\end{array}$ & $\$ 117,000,000$ & $\$ 1,710$ \\
\hline Total & $\$ 420,000,000$ & & $\$ 1,223,000,000$ & \\
\hline
\end{tabular}

\section{$2.5 \quad$ NON-ENERGY BENEFITS}

In addition to producing energy savings and energy cost savings, a sizable set of non-energy benefits can be attributable to low-income weatherization. Figure 2.7 illustrates the framework developed to organize the assessment of non-energy benefits. The framework has three main categories: societal benefits, rate payer benefits, and household benefits. Investments in weatherization create direct societal economic benefits (i.e., produce jobs and income multiplier effects). Reductions in energy use resulting from physical changes in the home result in environmental benefits (e.g., reductions in the emissions of harmful air pollutants), which are included in the societal bucket. Weatherization, through energy cost savings, directly impacts household income. Health and safety measures, combined with improvements in disposable income, impact the health and well-being of household members (e.g., by reducing instances of thermal stress, reducing asthma symptoms and increasing households' ability to afford prescriptions). Improved health outcomes can lead to societal benefits through decreases in expenses to public and private medical insurance plans. Ratepayers can benefit from decreases in subsidies to Percentage of Income Payment Programs (PIPPs), for example. The balance of this section addresses: environmental benefits; rate payer benefits; and household health and other household-related benefits. 


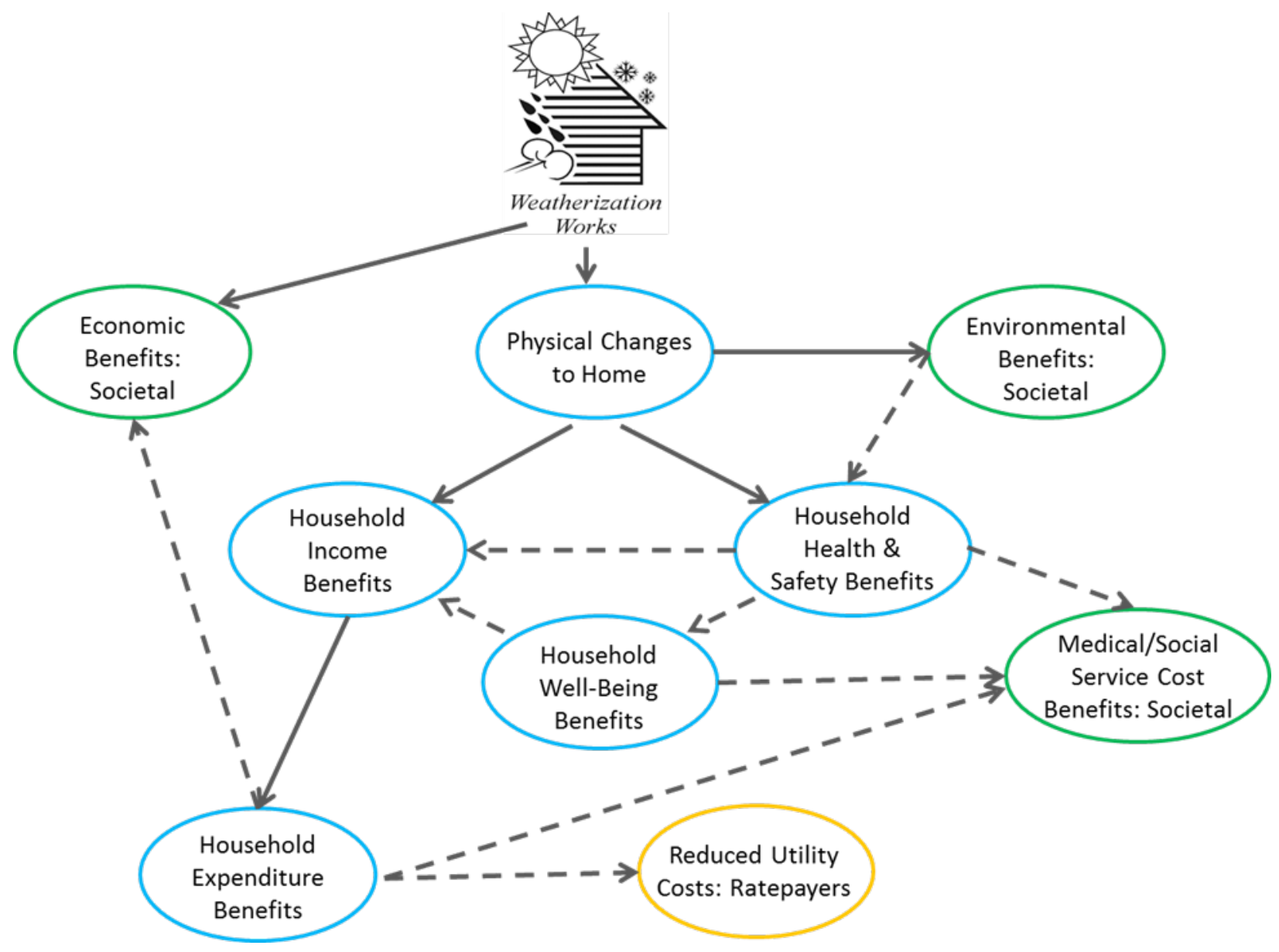

Figure 2.7 Framework for Understanding Non-Energy Benefits (solid lines represent direct, or first-order, pathways; dotted lines represent indirect, or second-order, pathways)

\subsubsection{Environmental Benefits}

One benefit of WAP is that reducing the amount of energy used in clients' homes reduces the emissions associated with the production and consumption of energy. Values for emissions reductions are estimated for: carbon, particulate matter, sulfur dioxide, nitrogen oxide, and volatile organic compounds. The environmental emissions benefit estimation procedure involves four steps:

1. Energy Usage Reductions (State-Level) - The 2010 program evaluation estimated energy savings per weatherized unit for each type of energy used in clients' homes (e.g., NG, electricity) for each building type (i.e., SF, MH, and MF).

2. Quantity of Avoided Emissions (State-Level) - Published data sources were used to estimate the avoided greenhouse gases, sulfur dioxide, nitrogen oxide and particulate matter emissions associated with the energy usage reductions for each type of energy. The analysis developed estimates of the average avoided emissions per housing unit at the state level and the aggregate avoided emissions per state. 
3. Value of Avoided Emissions (State-Level) - The dollar value of avoided greenhouse gas emissions was computed using guidance from Office of Management and Budget (OMB) and sulfur dioxides, nitrogen oxides, particulate matter, and volatile organic compounds was computed using the Air Pollution Emission and Policy Analysis Model (APEEP) as recommended by the National Research Council (NRC) in their 2010 Report to Congress. ${ }^{16}$ The analysis developed estimates of the average emissions benefit per housing unit at the state level and the aggregate emissions benefit per state.

4. National Averages and Aggregates - Using the state-level data, the analysis developed a weighted average avoided emissions and benefits per housing unit served by the program and aggregate avoided emissions and benefits for the overall program. The avoided emissions are expressed as avoided $\mathrm{CO}_{2}$ equivalents in metric tons, and average short tons of avoided for SOx, NOx, PM, and VOCs.

One important reason for developing estimates at the state level in Steps 1 and 2 is because environmental emissions rates for electricity generation vary by region. The valuation procedure done in Step 3 was conducted at the state level because the APEEP model estimates damages at the county level based on pollution sources and population. In addition, this approach furnishes data that can be useful to states for their own planning purposes. The lifetime $\mathrm{CO}_{2}$ emissions reductions are over 7 million metric tons and over 17 thousand short tons for criteria pollutants.

Table 2.9 presents the results of monetizing the present value of environmental emissions benefits by emissions type and housing type. ${ }^{17}$ The present value of these benefits for units weatherized in PY 2010 is $\$ 645,000,000$. This and the individual values by housing type and emissions type are about three to four times higher than the estimates for PY 2008 because of the higher number of units weatherized in PY 2010. These results are sensitive to the value of a metric ton $\left(\mathrm{CO}_{2}\right)$ or short ton of emissions reduced. For example, the value of a short ton of SO2 emissions reduced is much higher than the value for a metric ton of $\mathrm{CO}_{2}$ (i.e., $\$ 38$ versus $\$ 95,000$ ), primarily because studies that monetize the values of reductions of the criteria pollutants incorporate the human health benefits related to reducing exposures to outdoor air pollutants. The monetary values associated with reducing the criteria air pollutants by weatherizing LMF buildings are relatively larger because these buildings generally are located in areas with higher population densities and therefore, relatively speaking, more individuals benefit from the reduced emissions.

\footnotetext{
${ }^{16}$ National Research Council, 2010. Hidden Costs of Energy: Unpriced Consequences of Energy Production and Use. The National Academies Press, Washington, DC.

${ }^{17}$ See Retrospective Evaluation Report (Working Paper) Carroll et al. (2014e) and ARRA period Evaluation Report Carroll et al. (2015b) for more information on the environmental emissions benefits study.
} 
Table 2.9 Emissions Reductions Attributable to WAP for PY 2008 and PY 2010

\begin{tabular}{|c|c|c|c|c|c|c|c|c|c|c|c|}
\hline \multirow[b]{2}{*}{ PY 2008} & \multicolumn{5}{|c|}{$\begin{array}{l}\text { Thousands of Metric }\left(\mathrm{CO}_{2}\right) / \text { Short Tons } \\
\text { (lifetime of measures) }\end{array}$} & \multicolumn{5}{|c|}{$\begin{array}{l}\text { Monetized Benefit } \\
\text { (PV millions } 2013 \text { dollars) }\end{array}$} & \multirow{2}{*}{$\begin{array}{c}\text { Total } \\
\text { Monetized } \\
\text { Benefit } \\
\text { (millions \$) }\end{array}$} \\
\hline & $\mathrm{CO}_{2}$ & $\mathrm{SO}_{2}$ & $\mathrm{NO}_{\mathrm{x}}$ & $\mathbf{P M}$ & VOC & $\mathrm{CO}_{2}$ & $\mathrm{SO}_{2}$ & $\mathbf{N O}_{\mathrm{x}}$ & $\mathbf{P M}$ & VOC & \\
\hline $\begin{array}{l}\text { Single } \\
\text { Family }\end{array}$ & 1633 & 2.2 & 1.3 & 0.08 & .05 & $\$ 62$ & $\$ 59$ & $\$ 11$ & $\$ 4$ & $\$ 0.4$ & $\$ 136$ \\
\hline $\begin{array}{l}\text { Mobile } \\
\text { Homes }\end{array}$ & 302 & 0.4 & 0.2 & 0.02 & .009 & $\$ 12$ & $\$ 10$ & $\$ 2$ & $\$ 0.7$ & $\$ 0.05$ & $\$ 25$ \\
\hline $\begin{array}{r}\text { Small } \\
\text { Multifamily }\end{array}$ & 132 & 0.2 & 0.1 & .006 & .004 & $\$ 5$ & $\$ 3$ & $\$ 1$ & $\$ 0.3$ & $\$ 0.04$ & $\$ 9$ \\
\hline $\begin{array}{r}\text { Large } \\
\text { Multifamily }\end{array}$ & 178 & 0.4 & 0.1 & .005 & .003 & $\$ 7$ & $\$ 68$ & $\$ 5$ & $\$ 2$ & $\$ 0.1$ & $\$ 82$ \\
\hline $\begin{array}{l}\text { Total -- } \\
\text { Aggregate }\end{array}$ & 2246 & 3.3 & 1.8 & 0.1 & 0.07 & $\$ 85$ & $\$ 139$ & $\$ 19$ & $\$ 8$ & $\$ 0.6$ & $\$ 252$ \\
\hline PY 2010 & $\mathrm{CO}_{2}$ & $\mathrm{SO}_{2}$ & $\mathrm{NO}_{\mathrm{x}}$ & PM & VOC & $\mathrm{CO}_{2}$ & $\mathrm{SO}_{2}$ & $\mathrm{NO}_{\mathrm{x}}$ & PM & VOC & \\
\hline $\begin{array}{r}\text { Single } \\
\text { Family* }\end{array}$ & 5583 & 7.9 & 4.4 & 0.3 & 0.2 & $\$ 213$ & $\$ 194$ & $\$ 37$ & $\$ 15$ & $\$ 1.3$ & $\$ 460$ \\
\hline $\begin{array}{l}\text { Mobile } \\
\text { Homes }\end{array}$ & 888 & 1.6 & 0.7 & 0.06 & 0.02 & $\$ 34$ & $\$ 34$ & $\$ 4$ & $\$ 3$ & $\$ 0.1$ & $\$ 75$ \\
\hline $\begin{array}{r}\text { Large } \\
\text { Multifamily }\end{array}$ & 912 & 1.0 & 0.7 & 0.03 & 0.03 & $\$ 35$ & $\$ 58$ & $\$ 11$ & $\$ 4$ & $\$ 0.6$ & $\$ 109$ \\
\hline $\begin{array}{l}\text { Total -- } \\
\text { Aggregate }\end{array}$ & 7382 & 10.5 & 5.8 & 0.4 & 0.2 & $\$ 282$ & $\$ 287$ & $\$ 52$ & $\$ 22$ & $\$ 2$ & $\$ 645$ \\
\hline
\end{tabular}

* Single-family category includes the small multifamily building category in PY 2010.

\subsubsection{Macroeconomic Benefits}

This section summarizes work to estimate the macroeconomic benefits attributable to WAP. ${ }^{18}$ It is straightforward to assert that WAP has direct employment impacts. One can also argue that weatherization material and equipment purchases made by WAP at the local and state levels likely have indirect employment impacts. Moreover, the energy cost savings that households experience, and likely to spend on other goods and services, may also induce employment benefits.

To estimate the direct, indirect, and induced employment impacts, the retrospective evaluation team used a sophisticated macroeconomic modeling tool developed by Regional Economic Models, Inc. (REMI). The REMI model is a computable general equilibrium model, meaning that it is capable of simulating the multi-sector U.S. economy year-by-year over multiple decades. The model produces outputs in the form of changes in employment by sector, region, and year as well as changes in gross domestic product by region and year, reaching equilibrium of demand and supply for each modeled year.

The study team focused on estimating the macroeconomic benefits of WAP for PY 2008, including all leveraged funding spent in DOE units. The team apportioned WAP expenditures on energy efficiency measures to over 25 sectors of the U.S. economy, with the resulting impacts touching over 50 sectors. The estimates for PY 2010 were interpolated from the PY 2008 findings using a weatherization funding

\footnotetext{
${ }^{18}$ See Retrospective Evaluation report Burton et al. (2014) for additional details on this study.
} 
multiplier under the assumption that the fundamental structures and processes of the U.S. economy in PY 2010 did not differ from those of PY 2008.

The findings suggest that:

- Directly and indirectly, WAP was responsible for a combined 28,000 jobs in PY 2010;

- $\quad$ WAP generated $\$ 1.58$ billion in incomes;

- WAP increased national economic output by $\$ 4$ billion; and

- The national economic multiplier is 2.93 .

\subsubsection{Health and Household-Benefits ${ }^{19}$}

With reference to Figure 2.7, weatherization can directly benefit the health of occupants by increasing the home's comfort, reducing exposure to contaminants, and rectifying safety issues. As demonstrated above, weatherization can reduce energy costs. Figure 2.8 indicates many other ways that weatherization can increase household income. For example, weatherization can also directly reduce water costs. Occupants report improved health post-weatherization and for employed occupants, this means fewer missed days of work and more income. Higher incomes allow households to avoid other costs. For example, postweatherization, households take out fewer high-interest, short-term loans, which helps them avoid the interest payments. Being better able to pay their utility bills also helps households avoid late payment and disconnect penalties.

\footnotetext{
${ }^{19}$ See Tonn et al. (2014b) for a complete discussion of the methodologies used to monetize health and household benefits of weatherization.
} 


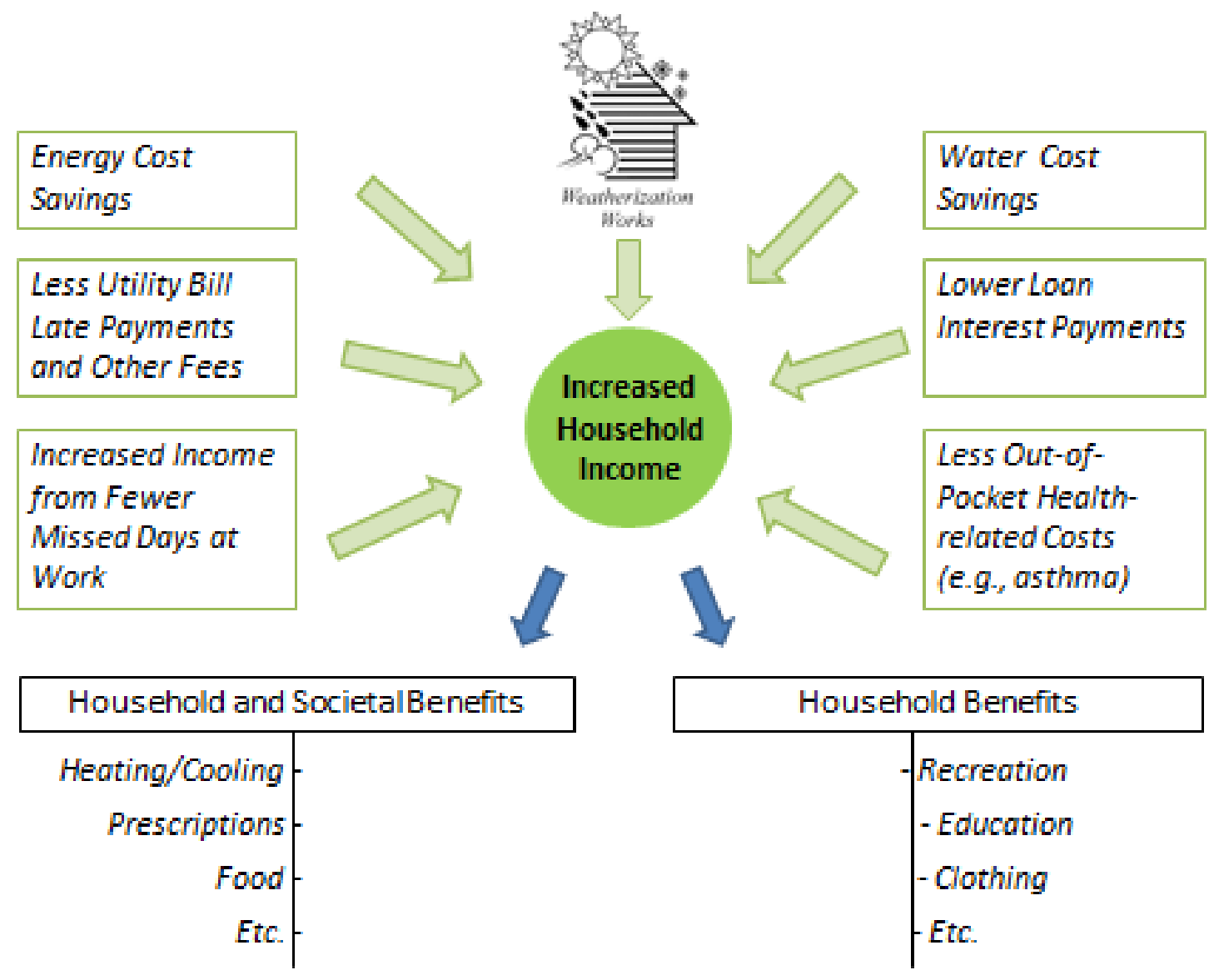

Figure 2.8 Potential Impacts of Weatherization on Household Disposable Income

Monetization of the benefits provides a way to combine these benefits with the energy cost savings and emissions benefits to develop a fuller picture of the total benefits versus costs of WAP. Twelve categories of health and household-related benefits were monetized as part of this evaluation. Methodologies used to generate the monetary estimates listed in Table 3.10 can be found in Tonn et al. (2014b). Here are several points to be considered with respect to these estimates:

- The methodologies used to estimate these benefits are based on a national survey of occupants (with a comparison group) and data collected on measures installed in homes by WAP, and on cost estimates for medical treatment were mined from national medical databases ${ }^{20}$ (i.e. Medical Expenditure Panel Survey (MEPS) and the Healthcare Cost and Utilization Project (HCUP));

- Household benefits are limited to financial benefits accruable directly to the households;

- Financial benefits due to improved health, for instance, that benefit health insurance plans are accrued to society in this framework;

\footnotetext{
${ }^{20}$ Hospitalization and emergency department costs were retrieved from an online database provided by the Department of Health and Human Services (DHHS) sponsored by the Agency for Healthcare Research and Quality (AHRQ). These data were collected through the Medical Expenditure Panel Survey (MEPS). The costs for a physician office visit were retrieved from a collection of databases sponsored again by AHRQ referred to as the Healthcare Cost and Utilization Project (HCUP).
} 
- The value of lives saved is considered societal; and

- The present values are calculated over a ten-year time frame using the 2013 discount rate published by OMB. ${ }^{21}$

Table 2.10 presents the estimates of the monetary value for these twelve non-energy benefits for households residing in single family and mobile homes. ${ }^{22}$ These estimates are grouped into three tiers according to the strength of the methodologies and data underlying the estimates. Tier 1 estimates can be considered to have the least amount of uncertainty, followed by the Tier 2 and Tier 3 estimates. The per unit estimates are the same as reported for PY 2008; however, the aggregate total for the WAP program accounts for the number of units weatherized in PY 2010 to capture the valuation of non-energy benefits for WAP during the ARRA period, which was nearly $\$ 4$ billion.

The highest benefit accrues from preventing instances of thermal stress from exposure to extreme cold indoor temperatures. This benefit has a high value because in a few cases, thermal stress can lead to death and preventing a death was valued at $\$ 7.5$ million in this analysis. Preventing deaths also weighed heavily in the benefits estimated for preventing instances of thermal stress (i.e., from exposure to extreme hot indoor temperatures), CO poisoning, and home fires.

\footnotetext{
${ }^{21}$ With the exception of the benefit of installing CO monitors, where present value was calculated over a 5-year period as the lifespan of CO monitors generally remains effective for an average of five years.

${ }^{22}$ SMF and LMF homes were not included in these analyses because clients living in these types of homes were not included as part of the national occupant survey and because weatherization of LMF buildings focuses more on central heating and water heating systems and common areas and less on individual units, which is hypothesized to have a very different impact on health and household-related non-energy benefits.
} 
Table 2.10 Present Value of Per Unit and WAP Program (ARRA period PY 2010) Health-Related Benefits of Weatherization

\begin{tabular}{|c|c|c|c|c|c|c|c|c|}
\hline \multirow{2}{*}{$\begin{array}{l}\text { Non-Energy Benefit } \\
\text { (Present Value Per Unit) }\end{array}$} & \multirow{2}{*}{ Total } & \multirow{2}{*}{$\begin{array}{l}\text { Total (Value of } \\
\text { Life Excluded) }\end{array}$} & \multicolumn{2}{|c|}{ Tier 1} & \multicolumn{2}{|c|}{ Tier 2} & \multicolumn{2}{|c|}{ Tier 3} \\
\hline & & & Societal & Household & Societal & Household & Societal & Household \\
\hline Asthma & $\$ 2,009$ & - & $\$ 1,852$ & $\$ 157$ & & & & \\
\hline Thermal Stress-Cold & $\$ 3,911$ & $\$ 172$ & $\$ 3,892$ & $\$ 19$ & & & & \\
\hline Thermal Stress-Heat & $\$ 870$ & $\$ 85$ & $\$ 855$ & $\$ 15$ & & & & \\
\hline Food Assistance Reduction & $\$ 832$ & - & $\$ 832$ & & & & & \\
\hline $\begin{array}{l}\text { Reduction in Missed Days at } \\
\text { Work }\end{array}$ & $\$ 201$ & - & $\$ 40$ & $\$ 161$ & & & & \\
\hline CO poisoning & $\$ 154$ & $\$ 7$ & & & $\$ 153$ & $\$ 1$ & & \\
\hline $\begin{array}{l}\text { Improvement in Prescription } \\
\text { Adherence }\end{array}$ & $\$ 1,929$ & - & & & $\$ 1,929$ & - & & \\
\hline $\begin{array}{l}\text { Reduction in Use of Short-Term } \\
\text { Loans }\end{array}$ & $\$ 71$ & - & & & - & $\$ 71$ & & \\
\hline Home Fires & $\$ 831$ & $\$ 175$ & & & & & $\$ 768$ & $\$ 63$ \\
\hline $\begin{array}{l}\text { Increased Productivity at Work } \\
\text { Due to Improved Sleep }\end{array}$ & $\$ 1,813$ & - & & & & & $\$ 1,813$ & - \\
\hline $\begin{array}{l}\text { Increased Productivity at Home } \\
\text { Due to Improved Sleep }\end{array}$ & $\$ 1,329$ & - & & & & & - & $\$ 1,329$ \\
\hline $\begin{array}{l}\text { Reduction in Low-Birth Weight } \\
\text { Babies from Heat-or-Eat Dilemma }\end{array}$ & $\$ 198$ & - & & & & & $\$ 198$ & - \\
\hline Total by Tiers (Present Value Per & $\$ 14.148$ & - & $\$ 7,471$ & $\$ 352$ & $\$ 2,082$ & $\$ 72$ & $\$ 2,779$ & $\$ 1,392$ \\
\hline (Uilit) & & & $\$ 7,8$ & & $\$ 2,1$ & & $\$ 4,1$ & \\
\hline Total by Tiers (Present Value & $\$ 3825626558$ & - & $\$ 2,047,168,576$ & $\$ 108,547,564$ & $\$ 550,996,491$ & $\$ 18,877,394$ & $\$ 732,973,061$ & $\$ 367,063,472$ \\
\hline & & & $\$ 2,155,7$ & 140 & $\$ 569,8$ & 885 & $\$ 1,100,0$ & 36,533 \\
\hline
\end{tabular}




\subsection{COST EFFECTIVENESS}

Table 2.11 presents a summary of the cost-effectiveness analyses by housing type for PY 2010 and PY 2008. The present values of the energy cost savings were calculated based on expected measure lifetimes, U.S. Energy Information Administration (EIA) estimates of future energy prices, and OMB discount rates for 2013. Only total measure installation costs are included in these analyses. The largest difference in cost-effectiveness between PY 2008 and PY 2010 falls in the LMF building category. In this category, the PY 2010 analyses include LMF outside of NYC. The large reduction in the percentage of LMF in the PY 2010 sample that heat with fuel oil explains the preponderance of the difference in savings to investment ratios for this sector. As noted above, the formula used to allocate WAP ARRA funds to the Grantees increased the proportion of funds flowing to hot climate regions of the U.S. Since these regions do not use expensive fuel oil and offer lower energy savings per unit, the lower SIRs for single family and mobile homes in PY 2010 are not unexpected (See Figures 2.9 and 2.10).

Table 2.11 Energy Cost Savings, Efficiency Measure Costs, and Cost-Effectiveness by Building and Fuel Type (2013 Dollars)

\begin{tabular}{|l|l|l|l|l|l|l|}
\hline \multicolumn{3}{|l|}{ PY 2008 } & \multicolumn{2}{l|}{ PY 2010 } \\
\hline & $\begin{array}{l}\text { PV Energy } \\
\text { Cost } \\
\text { Savings }\end{array}$ & $\begin{array}{l}\text { Measure } \\
\text { Costs }\end{array}$ & $\begin{array}{l}\text { Savings to } \\
\text { Investment } \\
\text { Ratio }\end{array}$ & $\begin{array}{l}\text { PV Energy } \\
\text { Cost } \\
\text { Savings }\end{array}$ & $\begin{array}{l}\text { Measure } \\
\text { Costs }\end{array}$ & $\begin{array}{l}\text { Savings to } \\
\text { Investment } \\
\text { Ratio }\end{array}$ \\
\hline Single Family* & $\$ 5,337$ & $\$ 3,096$ & 1.72 & $\$ 4,468$ & $\$ 3,990$ & 1.12 \\
\hline Mobile Home & $\$ 3,053$ & $\$ 2,961$ & 1.03 & $\$ 2,957$ & $\$ 3,737$ & 0.79 \\
\hline Small Multifamily & $\$ 4,618$ & $\$ 2,878$ & 1.60 & -- & -- & -- \\
\hline Large Multifamily** & $\$ 6,460$ & $\$ 3,336$ & 1.82 & $\$ 1,996$ & $\$ 2,976$ & 0.67 \\
\hline All types & $\$ 4,890$ & $\$ 3,070$ & 1.59 & $\$ 3,681$ & $\$ 3,745$ & 0.98 \\
\hline
\end{tabular}

* SF category includes SMF in PY 2010

** LMF category only includes buildings weatherized in New York City in PY 2008 
Site Built Homes

ECM SIR by

Climate Zone

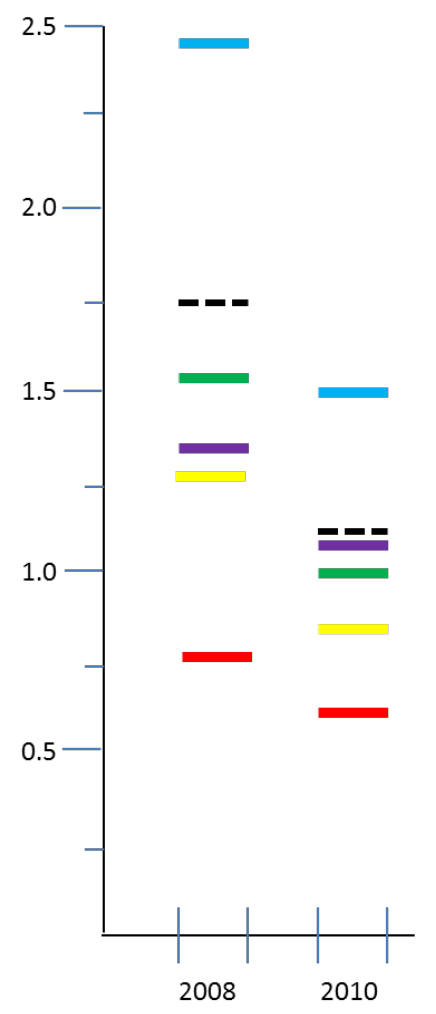

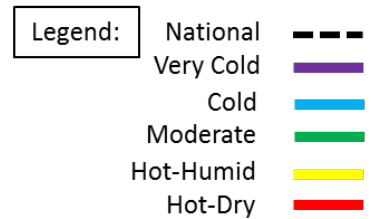

Site Built Homes

ECM SIR by

Fuel Type

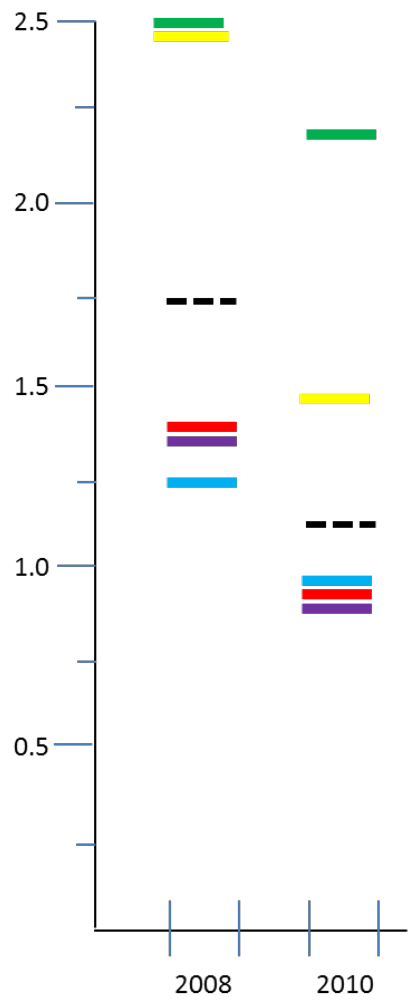

Legend: National $=\mathbf{E}$

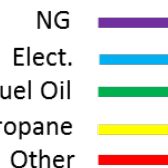

Site Built Homes

ECM SIR by

Funding Source

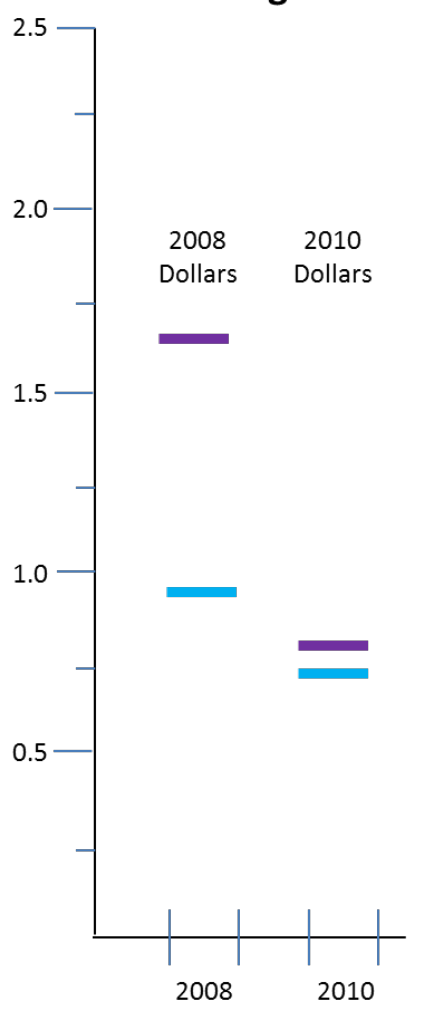

Legend: National -שי

Only DOE Funds

DOE + Non-DOE Funds

Figure 2.9 Cost-Effectiveness of Site Built Homes by Climate Zone, Heating Fuel Type, and Funding Source for PY 2008 and PY 2010 


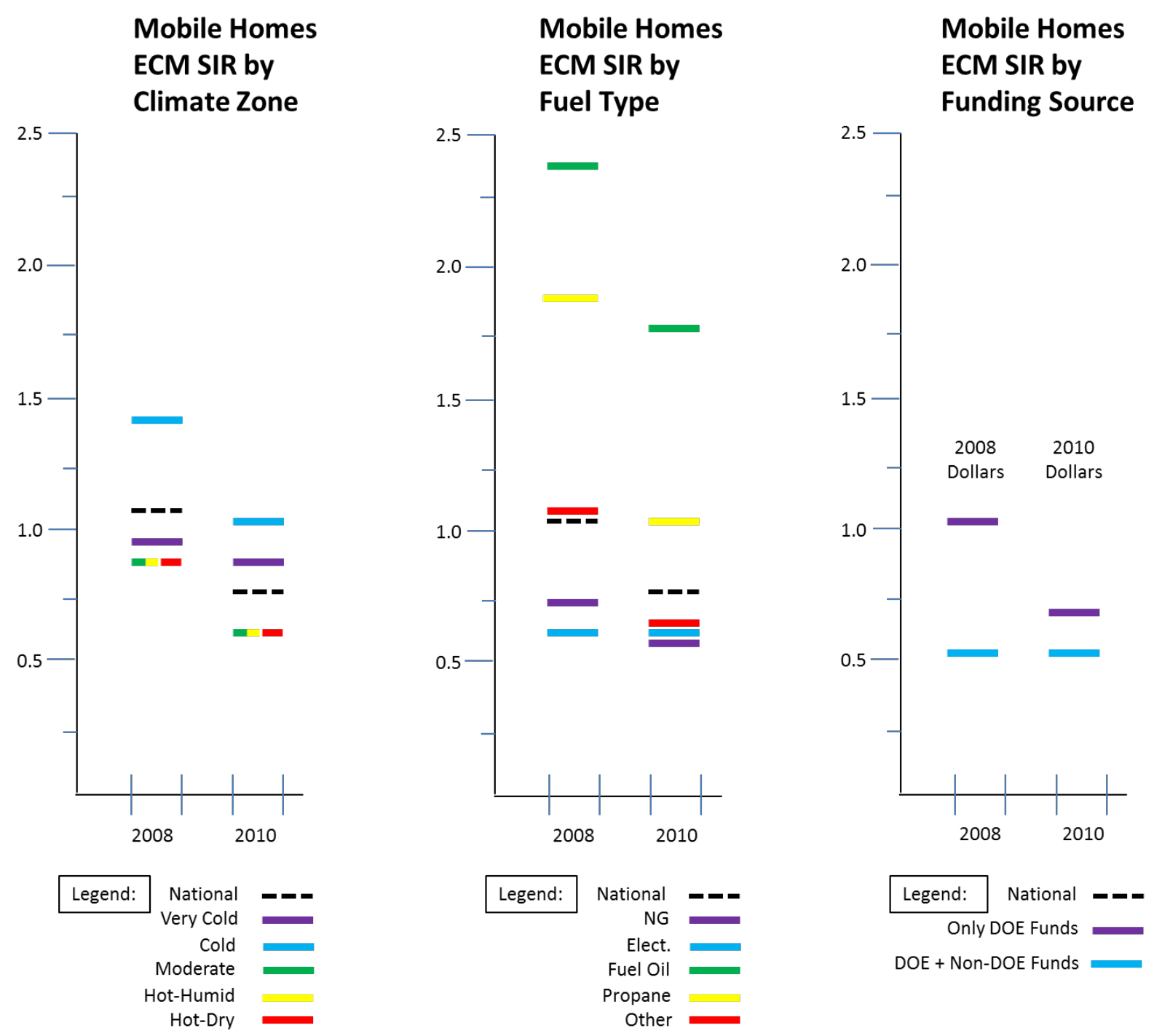

Figure 2.10 Cost-Effectiveness of Mobile Homes by Climate Zone, Heating Fuel Type, and Funding Source for PY 2008 and PY 2010

\subsection{COST EFFECTIVENESS: COMPARISON OF APPROACHES ${ }^{23}$}

Energy cost savings, non-energy benefit results, and cost effectiveness calculations are sensitive to what year the analysis is focused on. Results presented in Section 2 of this report for PY 2010 are based on 2013 as the analysis year to facilitate comparison with results from the retrospective period report. As the retrospective evaluation unfolded, it was decided to evaluate WAP during a year during the ARRA period. This decision was made, in part, in order to compare program performance during the last program year before the ARRA period with a program year during the ARRA period in order to better judge changes made in the program during the ARRA period. In order to allow a straightforward

\footnotetext{
${ }^{23}$ This subsection was added to this report in August 2015 to discuss how using different sets of assumptions can yield different cost effectiveness estimates, with reference to a fact sheet developed by the Office of Weatherization and Intergovernmental Programs (see http://weatherization.ornl.gov/WAP_NationalEvaluation_WxWorks_v14_blue_8\%205\%2015.pdf).
} 
Table 2.12. Total Benefits and Costs for WAP PY2008 \& PY 2010

\begin{tabular}{|c|c|c|c|c|}
\hline & $\begin{array}{c}\text { Present Value Per } \\
\text { Unit } \\
\text { PY } 2008\end{array}$ & $\begin{array}{l}\text { Present Value } \\
\text { Program } \\
\text { PY } 2008\end{array}$ & $\begin{array}{c}\text { Present Value Per } \\
\text { Unit } \\
\text { PY } 2010\end{array}$ & $\begin{array}{l}\text { Present Value } \\
\text { Program } \\
\text { PY } 2010\end{array}$ \\
\hline Energy Cost Savings & $\$ 4,890^{*}$ & $\$ 420,000,000$ & $\$ 3,681$ & $\$ 1,233,000,000$ \\
\hline Accrued to Households & $\$ 3,814$ & $\$ 327,800,000$ & $\$ 2,872$ & $\$ 962,000,000$ \\
\hline Accrued to Ratepayers & $\$ 1,075$ & $\$ 92,000,000$ & $\$ 809$ & $\$ 271,000,000$ \\
\hline $\begin{array}{l}\text { Environmental \& Water } \\
\text { Benefits }\end{array}$ & $\$ 3,118$ & $\$ 266,945,000$ & $\$ 2,130$ & $\$ 694,000,000$ \\
\hline Emissions Tier 1 & $\$ 2,932$ & $\$ 252,000,000$ & $\$ 1,944$ & $\$ 645,000,000$ \\
\hline Water Savings ${ }^{24}$ Tier 3 & $\$ 186$ & $\$ 14,945,000$ & $\$ 186$ & $\$ 49,000,000$ \\
\hline $\begin{array}{l}\text { Health \& Household- } \\
\text { related Benefits }\end{array}$ & $\$ 14,148$ & $\$ 1,166,000,000$ & $\$ 14,148$ & $\$ 3,826,000,000$ \\
\hline Tier 1 & $\$ 7,823$ & $\$ 657,000,000$ & $\$ 7,823$ & $\$ 2,156,000,000$ \\
\hline Tier 2 & $\$ 2,154$ & $\$ 174,000,000$ & $\$ 2,154$ & $\$ 570,000,000$ \\
\hline Tier 3 & $\$ 4,171$ & $\$ 335,000,000$ & $\$ 4,171$ & $\$ 1,100,000,000$ \\
\hline Total Benefits & $\$ 22,156$ & $\$ 1,852,945,000$ & $\$ 19,959$ & $\$ 5,753,000,000$ \\
\hline Total Costs ${ }^{1}$ & $\$ 4,695$ & $\$ 403,000,000$ & $\$ 6,812$ & $\$ 2,320,000,000$ \\
\hline DOE & $\$ 2,295$ & $\$ 197,000,000$ & $\$ 5,926$ & $\$ 2,018,400,000$ \\
\hline Leveraged Funds & $\$ 2,400$ & $\$ 206,000,000$ & $\$ 886$ & $\$ 301,600,000$ \\
\hline $\begin{array}{l}\text { * - Excludes LMF outside } \\
\text { ** - Excludes LMF }\end{array}$ & & & & \\
\hline
\end{tabular}

comparison between these two years, it was decided that a common analysis year should be chosen. The common analysis year chosen was 2013 because that was the year when it was expected that both evaluations were to be completed. Thus, the energy, benefit, and cost-effectiveness estimates in various tables in Section 2 are based on OMB published discount rates for $2013(\sim 0.8 \%$ for benefits over 20 years) and energy price forecasts that begin in that year. In this way, differences seen in program cost effectiveness between PY 2008 and the ARRA period will be due primarily to estimated energy savings, not on financial and forecast assumptions. The choice of OMB discount rates for these estimates is consistent with choices made by other major evaluations, including evaluations of the State Energy Program and the Energy Efficiency and Conservation Block Grant Program.

Others can argue, with merit, that it is important to present results related to energy savings and costeffectiveness using the financial assumptions for the year under study. Thus, with respect to the ARRA period evaluation, the year under study was PY 2010. The single family, mobile home, small multifamily, and large multifamily impact reports all contain energy savings and cost effectiveness estimates tethered to 2010 OMB discount rates ( 2.7\%) and energy price forecasts made at that time. The impact of using 2013 as the analysis year rather than 2010 can be demonstrated by examining the WAP energy savings. As shown in Table 2.13, the present value of the energy savings for WAP is estimated to be \$1.1 billion using PY 2010 energy savings results and discount rate and energy price forecast assumptions for that time period, This estimate is lower than the estimate of $\$ 1.2$ billion using 2013 dollars primarily because the OMB discount rates for 2013 were historically low.

The results presented in Table 2.13 for the program also illustrate different ways of using the results from this evaluation to produce cost effectiveness estimates and how cost effectiveness estimates are sensitive to what benefits and costs are included in the numerator and denominator of the SIR calculations. For example, one could divide energy cost savings by energy measure costs to produce a "measure” SIR. This

\footnotetext{
${ }^{24}$ For a description of the water savings non-energy benefit, see Carroll et al. (2014e).
} 
results in a measure SIR of 1.04 using 2013 dollars and about 0.9 using PY 2010 dollars. A “program” SIR could also be calculated by dividing total benefits (i.e., energy savings and non-energy benefits) by total costs. Using 2013 dollars, this results in a program SIR of 2.93, where all the non-energy benefits as summarized in Table 2.12 were included in the total benefits and the total cost includes all administrative costs and H\&S costs in addition to energy measure costs. In the 2010 dollars column, a program SIR of 3.2 is calculated by adding the energy cost savings to just a subset of the health-related benefits (for a total benefit of $\$ 13,167$ ) and dividing by the average measure costs plus an additional $15 \%$ to account for average health \& safety investments in homes.

Similarly, Table 2.14 addresses single family cost effectiveness specifically. The lower OMB discount rates for 2013 yield a higher present value of energy cost savings per single family weatherized, though the annual energy cost savings estimate are approximately the same. The two approaches yield similar measure SIRs: 1.12 using PY 2013 dollars and 1.01 using PY 2010 dollars.

Table 2.13 Total (Program) Benefits and Costs for WAP PY 2010: Comparison of Approaches

\begin{tabular}{|r|c|c|}
\hline & 2013 Dollars & 2010 Dollars \\
\hline Program Energy Cost Savings & & \\
\hline Total (present value) & $\$ 1.2$ billion & $\$ 1.1$ billion \\
\hline $\begin{array}{r}\text { Total Program Benefits Per Unit (energy costs savings plus } \\
\text { non-energy benefits) }\end{array}$ & $\$ 3,681$ & $\$ 3,190$ \\
\hline Costs & $\$ 19,959$ & $\$ 13,167$ \\
\hline \multicolumn{1}{r|}{ Total per Unit } & $\$ 6,812$ & \\
\hline Cost Effectiveness - SIR & $\$ 3,745$ & $\$ 6,812$ \\
\hline Measure (energy savings only) & 1.0 & \\
\hline Program & 2.93 & 0.9 \\
\hline
\end{tabular}

Table 2.14 Single Family Benefits and Costs for WAP PY 2010: Comparison of Approaches

\begin{tabular}{|c|c|c|}
\hline & 2013 Dollars & 2010 Dollars \\
\hline Annual Energy Costs Per Unit & $\$ 1,874$ & $\$ 1,863$ \\
\hline \multicolumn{3}{|l|}{ Energy Cost Savings } \\
\hline Annual per unit & $\$ 224$ & $\$ 223$ \\
\hline Present value per unit & $\$ 4,468$ & $\$ 3,803$ \\
\hline Energy Measure Costs per Unit & $\$ 3,990$ & $\$ 3,777$ \\
\hline Measure Cost Effectiveness & 1.12 & 1.01 \\
\hline
\end{tabular}

\section{$2.8 \quad$ SUMMARY}

Table 2.12 presents a summary of the total program benefits and costs for WAP for PY 2008 and 2010 for all weatherized units. The average cost per unit weatherized in PY 2010 is \$6,812, which includes all programmatic costs (i.e., measure costs, administrative costs, training and technical assistance). The average energy cost savings is $\$ 3,681$. Because numerous households whose homes were weatherized participate in utility administered PIPPs that are subsidized by ratepayers, approximately $22 \%$ of the energy cost savings accrue to ratepayers. The combined present value of the energy and non-energy benefits per unit is approximately $\$ 20,000 .{ }^{25}$ Accounting for the units weatherized in PY 2010, the total

\footnotetext{
${ }^{25}$ This study assumes there is no free-rider issue. In other words, none of the households whose homes were weatherized would have undertaken weatherization without WAP. This assumption is justified given that all homes in the program are low-income
} 
present value of the benefits exceeds $\$ 5.7$ billion. It should be noted that there are uncertainties in all of these estimates. However, the total estimates are conservative in several manners. First, the health and household-related benefits do not take into account subjective benefits enjoyed by households with respect to comfort, improved health and other factors. Second, these non-benefits were not estimated for the large multifamily component of WAP.

Lastly, numerous other non-energy benefits were not monetized by the evaluation, including potential health impacts of refrigerator replacement (i.e., as related to the prevention of food poisoning), health benefits attributable to minor home repairs (e.g., reducing trips and falls), increased home value resulting from the value of the weatherization investments, interest payments on late payments of utility bills, reduced forced mobility, reduced emissions of heavy metals, improvements in national security, and the value of free training provided to weatherization staff. Ratepayer benefits not addressed include: lower bad debt write-off, reduced carrying costs on arrearages, fewer notices and customer calls, fewer emergency gas service calls, reduced transmission and distribution costs, and reduced peak electricity demands.

and the national occupant survey documents problems these households have in paying everyday bills. It should be noted that these estimates also do not include spillover benefits, despite the fact that spillover was documented by the Social Network Study (See Recovery Act report: Rose et al. (2014a). 


\section{SPECIAL STUDIES}

\subsection{OVERVIEW}

This section of the report presents summaries of results from eight special studies that were also conducted as part of the WAP ARRA period evaluation. In order of presentation, the studies are:

- Weatherization Plus Health - Opportunity Council (3.1)

- Weatherization Experiences Social Networking Study (3.2)

- Occupant Survey Analyses - Budgets, Energy Behaviors (3.3)

- Weatherization Deferral Study (3.4)

- Territories Study (3.5)

- Weatherization Post-Recovery Act Survey Results (3.6)

- AC Pilot Study (3.7)

- $\quad$ Refrigerator Study (3.8)

\subsection{WEATHERIZATION PLUS HEALTH - OPPORTUNITY COUNCIL ${ }^{26}$}

This section presents results from analyses conducted on asthma-related housing characteristics, environmental triggers, health status and healthcare data collected from 49 households that received some form of weatherization and healthy homes interventions through selected WAP agencies in Northwestern Washington State between 2006 and 2013.

Healthy housing intervention programs aim to improve health outcomes for occupants through improvements in dwelling quality. Households of low socioeconomic status (SES) are more likely to reside in homes with structural damages, elevated levels of lead, indoor allergens, radon, environmental contaminants, and other dwelling quality issues known to have pathogenic effects on health. ORNL and the Opportunity Council, a Community Action Agency (CAA) in Northwestern Washington State, partnered to collect and analyze caregiver-reported, field-collected, and healthcare records data to discern potential asthma-related benefits of these programs in the areas of improved dwelling quality, caregiver observed asthma morbidity, and direct healthcare utilization and costs. The study enrolled Medicaidinsured Healthy Homes, Weatherization plus Health, and WAP only participants with caregiver-reported asthma diagnosis to valuate or monetize intervention impacts on healthcare costs.

Comparing occupant-reported and field-collected data from the three study groups mentioned above (referred to herein as Healthy Homes Only, Weatherization plus Health, and WAP Only) pre- and postintervention revealed that both weatherization (e.g., air sealing, insulation, heating equipment installation and maintenance) and healthy housing interventions (e.g., flooring replacement, ventilation, dust mite mattress and pillow covers, education) were impactful with respect to improving dwelling quality and reducing home sourced evidence-based asthma triggers. These data suggest benefits accrue through the delivery of WAP in concert with the Healthy Homes intervention, which is expected as both programs fund the provision of different, but complimentary, services. Observations of improved dwelling quality (e.g., decrease in moisture and mold issues, improved thermal comfort) and health were made. Caregiverreported information revealed child health improvement, in general, post-intervention. All households within the Healthy Homes groups and $82 \%$ of the WAP Only group reported children "seemed to feel better.” All households within the Weatherization Plus Health group, 94\% of the Healthy Homes Only group, and $64 \%$ of the Weatherization Only group reported children in their care "could run and play longer” post-intervention. These results further substantiate the claim that both weatherization and healthy

\footnotetext{
${ }^{26}$ Text in this section is drawn from the Executive Summary of Rose et al. (2015a).
} 
housing interventions improve dwelling quality with the potential for synergistic benefits of WAP plus healthy housing evident.

Changes within the indices selected to measure asthma morbidity for Medicaid-insured study participants (23 of the 74 individual cases in the study had useable records data) residing in homes that received either Weatherization Plus Health, Healthy Homes, or standard WAP services, suggest statistically significant decreases occur in healthcare utilization (measured in asthma-related claims) and costs post-intervention. More specifically, a statistically significant decrease was observed in annualized asthma-related Medicaid costs for all study groups collectively (by \$421). The average number of claims paid by the Washington State Medicaid program per month also decreased significantly within the Weatherization plus Health (by 0.42 claims) and WAP only (by 0.91 claims) groups. It appears as though the Healthy Homes sample in this study included participants with higher baseline amounts of claims and costs per month overall and thus, may have benefited from the additional measures provided through Weatherization plus Health and WAP. The public health community has given recent attention to super-utilizers of the healthcare system to help alleviate health disparities in the U.S. disproportionately burdening households of low SES and communities of color, and to reduce healthcare costs accruing from this population. Based on these data it is reasonable to propose that the Opportunity Council and other healthy housing programs give high priority to families with children with severe asthma considered to be super-utilizers of the healthcare system or to members of populations or demographics disproportionately burdened with asthma (e.g., American Indians in Washington State) to maximize the potential impact of these programs.

This study sought to explore the potential for assessing programmatic impacts through outcome measures contained in linkable Medicaid records-only and physician records research. Through this study we can conclude that it is possible to collect and link these data at individual and household levels.

The research collected through this quasi-experimental study suggests that Weatherization plus Health, Healthy Homes, and WAP all contribute to this effort, but additional research is required to better attribute the reductions in Medicaid claims and costs to these programs, and to generalize the results to all program recipients. Promising savings were observed across all study groups, but sample sizes in some instances were too small to determine statistical significance.

Overall, the services delivered by the participating agencies in this study significantly reduced healthcare costs for Medicaid-insured asthmatic children residing in Northwestern Washington State. However, evaluations of asthma intervention programs are often befogged by the numerous confounding factors (e.g., demographics, geographic location, severity of illness, exposure to environmental triggers) and difficult to measure benefits associated with improved health outcomes (e.g., reduced psychosocial stress, productivity gains, educational attainment). Although a large body of evidence has amassed over the past several decades suggesting causality and associations between poor indoor environmental quality (IEQ) and health, urgent recommendations for further research to study direct relationships between specific housing intervention measures, indoor exposure disparities and health outcomes for better understanding of the determinants of these exposures continue to be made by leading experts in the public health and housing domains, including the impacts attributable to WAP specifically. Further investigation of the cumulative exposure to indoor contaminants, known to have pathogenic effects on health, contributes to a better understanding of indoor environmental justice and improves the efficacy of programs charged with creating parity for groups burdened by adverse health outcomes related to IEQ. 


\subsection{WEATHERIZATION EXPERIENCES SOCIAL NETWORKING STUDY ${ }^{27}$}

This report presents in-depth analyses from ORNL's social network study, “Assessing the Potential of Social Networks as a Means for Information Diffusion: The Weatherization Experiences (WE) Project”, an exploratory study conducted as part of the ARRA period WAP evaluation. The WE Project explored the potential for WAP recipients and staff to influence energy savings beyond their homes and day jobs. Several studies conducted through ORNL's evaluation of WAP found that the program has the ability to profoundly impact the lives of the people it serves (Tonn, Rose and Hawkins, 2014a). Recipients of WAP provided statements ranging from the newfound ability to pay utility bills and prescription medication to reduced emergency department visits for asthma and medical conditions associated with thermal stress. Through this exploratory research project, the stories of hundreds of weatherization recipients and providers were documented. The WE Project was designed to further investigate whether or not shared experiences with weatherization have the power to stimulate home energy saving action within an individual's social network.

Individuals belong to complex webs of social networks ${ }^{28}$ comprised of multiple types of relationships, interactions and functions. The goal of this special study was to explore linkages between individuals within these multi-level and multi-relational social systems starting with the initial communication by the WAP agency, staff, or recipient. In this report we refer to these potential catalysts for spurring home energy-efficiency as "nodes." This reading of the community helps understand if and what type of weatherization information is being shared (i.e., energy cost savings, health benefits), what core values are in place that might support or hinder adoption of new energy usage behaviors, and the motivating factors contributing to action taken after information is received from a known, or trusted source. The WE Project sought to identify topics most communicated and to measure the impacts of these shared weatherization experiences on the actions of others. The primary goal of this study was to capture any energy and non-energy impacts resulting from shared communication as additional benefits attributable to WAP.

To conduct the WE Project, weatherization staff and recipients of the program were recruited by 10 local agencies that had been purposively selected for the WAP national evaluation's case study report ${ }^{29}$. Those recruited were then asked to conduct interviews with members of their social network that they had communicated weatherization information to. This technique, known as participatory research, allowed for information to be collected starting with the initial recipient or staff as a node of communication. These individuals were trained by the evaluation team to administer semi-structured questionnaires (Appendix C) to their friends and family to unearth whether or not their own experience with weatherization incited actions to increase home energy efficiency, and to capture the motivations for those actions. The interviews sought to answer five overarching questions through the efforts of the researchers: Who did you tell? What did you say? What did they hear? What did they do? and Why? The interviewers then asked the members of their social network if they had discussed weatherization with anyone within their social network. This snowball sampling method allowed for an assessment of the diffusion of information into the second degree of separation from the initial node (household recipient or staff). "Diffusion" is defined herein as the process in which new ideas or innovations are communicated over time through members within a social network and diffusion research explores the "capacity for networks to either promote or constrain the spread" of these new ideas.

\footnotetext{
${ }^{27}$ This text is drawn from the Executive Summary of Rose, E., Hawkins, B., Tonn, B., Conlon, B., and Treitler, I. (2015b).

28 "Social networks" is defined in this report as a self-identified set of dyadic (group of two) social relationships and/or interactions (i.e., kinship, friends, and neighbors).

${ }^{29}$ See Tonn, Rose and Hawkins (2014a).
} 
Four key findings were revealed: (1) weatherization experiences are indeed communicated through social networks; (2) communications do influence action and behaviors as measured by counts of reported contacts with professional weatherization providers, completing "Do-It-Yourself” (DIY) home projects, and reported changes in energy conserving behavior; (3) WAP recipients can be trained to extract targeted information that might have otherwise been unattainable; and (4) opportunities exist to maximize the impact of social networks (i.e., provide individualized and transformative education and awareness for recipient understanding and adoption of energy and non-energy related behavior based on underlying motivating factors and existing values).

Findings from the interviews reveal that weatherization information diffused into social networks does in fact influence home energy related actions and behaviors. Taking action is defined in this study as contacting a WAP agency, or a private contractor, or completing any DIY projects. Of those interviewed, $37 \%$ reported that they contacted a WAP agency, 7\% contacted a private contractor or a home energy savings program, and 28\% completed some type of DIY weatherization measures. After making initial contact, $91 \%$ of those who contacted a local WAP agency filled out an application for services resulting in 54\% of those having at least an audit completed. Of those that contacted a non-WAP provider for weatherization services, $61 \%$ had an audit or weatherization work completed. These are valuable findings evidencing that WAP recipients can influence investments in energy conservation measures within and beyond the WAP income eligible population.

The WE Project found that the motivating factors contributing to energy saving action involve both selfserving (e.g. energy affordability, home comfort, and health) and altruistic benefits (e.g., environmental conservation). Also found was a statistically significant correlation between those who contacted a private contractor and those reporting being motivated to take action out of concern for the environment. For this group, environmental conservation was the most reported motivating factor. For those who contacted a WAP provider, the top two statistically significant reported motivating factors were "cold winter" and "difficulty paying utility bills."

Results from the completed interviews offer insight into program utilization process and provide data for secondary impact analysis of WAP's influence on home energy conservation. This research also sought to contribute to the general discussion on the impact of communicating personal or professional experiences with home-related energy efficiency activities and experiences on the actions and adopted behavior of individuals with whom the information was shared. To expound on the study's results, this report explores the potential utilization of existing social networks for the diffusion of novel home energy saving information, public health education related to IEQ, and climate change mitigation and adaptation strategies benefiting vulnerable persons and populations, such as those targeted by WAP.

\subsection{OCCUPANT SURVEY ANALYSES - BUDGETS, ENERGY BEHAVIORS ${ }^{30}$}

This report presents in-depth analyses of survey data collected from recipients of services funded by WAP. A task that bridged the retrospective and ARRA period evaluations was the administration of a national weatherization client (i.e., occupant, recipient) survey. Briefly, this survey included both a treatment group and a comparison group. Potential respondents for the treatment group were randomly selected from lists of single family and mobile homes about to receive their energy audits provided by 220 randomly selected Subgrantees. Potential respondents for the comparison group were randomly selected from lists of single family and mobile homes that were weatherized by these Subgrantees one year previously. The approximately 45 minute phone survey was also administered post-weatherization, approximately eighteen months later, to both the treatment group and again to the comparison group. The

\footnotetext{
${ }^{30}$ The text is drawn from the Executive Summary of Tonn E., Rose E., and Hawkins, B. (2015a).
} 
survey contained questions about energy end uses, energy consumption behavior, health, household budget issues, and demographics.

Two previous reports have utilized the data collected from the administration of this occupant survey. The first presented descriptive statistics for key questions using only the pre-weatherization results (Carroll et al. 2014a). The second used pre- and post-weatherization results pertaining to the human health to estimate the monetary value of these non-energy benefits of low-income weatherization (Tonn et al. 2014b). This report complements the other two reports. Specifically, it addresses three topics not thoroughly addressed by the previous reports: budget issues faced by WAP recipient households; energy conservation behaviors; and use of programmable thermostats.

WAP recipients can be characterized by the number of budget issues they face. For example, do they trade-off purchasing food to pay utility bills or take on high interest, short-term loans to pay for other bills? Approximately 10\% of households reported experiencing at least eight of ten serious budget issues. Another 13\% experienced about six in ten issues. Conversely, almost half of the recipients experienced less than one in ten of the issues. Households that experienced the most budget issues were also much worse off with respect to other health and home conditions than households with few budget issues. The former experienced more flu, colds, and thermal stress events, and their homes had significantly more issues with respect to odors, mold, and infestations. Overall, households that are larger, live in larger homes, have lower incomes, and are of working age experience more budget problems. These homes showed the most improvement post-weatherization across a large number of variables, though these households still faced more budget issues than most that received weatherization.

With respect to energy use, the results suggest that the weatherization process did not have significant impacts on household energy conservation behavior. For example, about the same number of households washed and dried their clothes with full loads (approximately $80 \%$ and $76 \%$, respectively) pre- and postweatherization. Rates for unplugging appliances ( 27\%) and hanging clothes out to dry ( 37\%) were also about the same. In a few cases, energy conservation behaviors increased post-weatherization (e.g., treatment homes purchasing Energy Star appliances increased from 60\% pre-weatherization to $76 \%$ postweatherization). In about an equal number of cases, energy conservation behavior decreased (e.g., 73\% of comparison group homes purchased compact florescent lights (CFLs) pre-weatherization, dropping to $64 \%$ post-weatherization). Thermostat settings also showed little change post-weatherization, which suggests little or no take back of energy savings associated with home heating.

On the other hand, on average, the percentage of households that heated or cooled all of the rooms in their homes increased post-weatherization regardless of the number of rooms in the home or climate zone, which could indicate a small take back effect. Weatherization did not appear to impact the use of cross ventilation or methods to reduce heat gain in the summer (e.g., closing drapes).

Similar to the budget issue analysis, households can be clustered by their energy conservation behaviors. About 25\% of the households exhibit less than 2 energy conservation behaviors (out of a core of six potential behaviors), whereas only 11\% exhibit more than 4 (4.6 on average). Unlike the budget issue analysis, household energy conservation behaviors appear to be idiosyncratic. Very few independent and demographic variables correlate with energy conservation behaviors

Most of the analyses reported below suggest that client education as implemented by WAP has little to no impact on energy conservation behaviors post-weatherization. The number of client education "touches" (e.g., at time of the audit, at final inspection), the number of topics covered per touch, and the number of client education items given households were all insignificantly correlated with changes in energy conservation behaviors. Households that received specific client education on topics that related to specific energy conservation behaviors did no better with respect to energy savings than households that 
did not receive such client education. The only significant relationship found was this: separate client education visits had a positive and statistically significant impact on energy conservation behavior postweatherization.

Use of thermostats is important with respect to household energy consumption. Almost every Subgrantee reported covering thermostat use as part of its energy education program. It was reported above that thermostat settings did not change much pre- to post-weatherization. It was also found that the use of programmable thermostats did not change appreciably post-weatherization. Households did not make use of the full capabilities of their programmable thermostats. Fewer households programmed, reprogrammed or overrode their programmable thermostats post-weatherization. Recipients' knowledge about thermostat operation is also deficient, as most households failed to correctly answer 3 or four basic questions about thermostat systems, both pre- and post-weatherization.

Overall, these results support two general conclusions. One, focusing weatherization on the $10-25 \%$ of households that suffer the most budget issues could yield the highest marginal returns with respect to health- and household-related non-energy benefits. Future research is needed to provide insights about what percentage of these weatherization households are also considered super-utilizers of medical services. Future research is also needed to determine whether households that could most benefit from weatherization from a health perspective are also homes that have the highest potential energy savings.

Unfortunately, the WAP evaluators were not able to match households that answered the occupant survey with households for which energy consumption data were collected pre- and post-weatherization.

The second general conclusion is that there is ample space to improve how client education is implemented by WAP. The results suggest that separate client education visits are the most effective in changing energy conservation behaviors. Future research is needed to assess the benefits versus the costs with respect to expanding this intensive type of client education. 


\subsection{WEATHERIZATION DEFERRAL STUDY ${ }^{31}$}

This study provides descriptive statistics for estimated deferral rates and reasons, and assesses interview responses received from a sample of Subgrantees and weatherization recipients describing their experiences with deferrals or 'walk-aways' from homes resulting in either suspended or final deferment of WAP. Findings suggest deferral of weatherization can be categorized into two areas; health and safety hazards, and repair requirements (e.g., roof replacement). Other reasons involve situations where a home is being remodeled or is condemned, client refusal of measures, or observations of illegal activities. Agency, regional, state and federal field guides or manuals provide guidance for when a deferral of weatherization is required and acceptable reasons for deferment. Occupational Safety and Health Administration (OSHA) standards for health and safety for weatherization auditors, contractors, and crew members are adhered to and are often referred to within the health and safety sections of the field manuals. Categories of acceptable reasons for deferred treatment serve to ensure health and safety precautions are taken for both weatherization staff and occupants while adhering to the overarching costeffective energy saving mission of WAP.

An additional analysis of deferral-related records was performed with 43 participating weatherization agencies in 19 states; in-depth interviews were conducted with 20 Subgrantees reporting a deferral rate of over 5\%, 10 agencies reporting low-deferral rates (5\% and below) and 10 agencies reporting high-success with completing weatherization in over $50 \%$ of the homes previously deferred. Open-ended guided questionnaires were developed and conducted with staff from the sampled agencies to capture causes of deferrals; assessment of impact of accessibility to standard deferral plans; utilization of standard forms; auditor knowledge and utilization of intra- and inter-agency resources and referrals targeting the specific cause(s) for the deferral; innovative techniques for addressing potential deferral situations; range of subjective or ethnocentric responses to home conditions or client behavior; as well as other characteristics of the homes and weatherization personnel. Process evaluation interviews were completed with 119 clients engaged in the deferral process. Interviews with these sampled agencies and clients were conducted between January 2013 and September 2013.

The overall goal of the special study was designed with two primary objectives. The first objective was to identify patterns across estimated deferral incidence rates and success with weatherization post-deferral. The second was to identify both strengths and weaknesses within the deferral process at the local agency level from the agency and client perspective and to explore the impacts on clients and the overarching WAP agenda - to improve the energy efficiency in the housing stock occupied by income eligible households. This study is unique as it involves in-depth interviews with deferred clients to better understand their experience with the process and to better characterize this population compared to the WAP-eligible population served.

\section{Program Characterization Results}

Program characterization surveys were administered to all WAP Grantees as part of the ARRA period evaluation for PY $2010^{32}$. WAP Grantees include all states, the District of Columbia and five U.S. territories. All Subgrantees (agencies) in all states, and 350 weatherization auditors were also surveyed. Unfortunately, because deferred weatherization cases are often not tracked by the local Subgrantees, and therefore not tracked at the Grantee level, broad categories to determine approximate deferral rates were used. A low weatherization deferral rate of $1-5 \%$ was the most frequent response provided by Grantees (53\%), Subgrantees (47\%), and weatherization staff (68\%). Over 20\% of Subgrantees report deferral rates over $11 \%$ with $4 \%$ of Grantees and $10 \%$ of Subgrantees reporting that more than $21 \%$ of homes in

\footnotetext{
${ }^{31}$ The text is drawn from the Executive Summary of Rose, E., Hawkins, B., Tonn, B., Ashcraft, L., and Miller, C (2015).

${ }^{32}$ See retrospective evaluation report, Bensch et al. (2014).
} 
their service territories are deferred services. The surveys then asked for the approximate percentage of homes that were successfully weatherized after the deferral of services. The majority of Grantees and Subgrantees report weatherizing up to $25 \%$ of homes after households re-entered the queue upon addressing all reasons for deferred services. The top five reasons for weatherization auditors frequently or very frequently deferring homes involved: (1) excessive mold or moisture; (2) unsanitary conditions: (3) excessive repair that is beyond the scope of WAP; (4) structurally unsound or dilapidated unit; and (5) unsafe electrical, plumbing, or mechanical equipment . Overall, Grantee, Subgrantee and weatherization staff responses describing the weatherization deferral process were fairly consistent.

\section{Occupant Survey}

A national occupant survey ${ }^{33}$ of randomly sampled pre-weatherized (treatment) and comparison group (one year post-weatherization) households was administered as part of the larger WAP national evaluation. Findings from the survey revealed that $30 \%$ of those on the agency audited list, and called for pre-weatherization survey responses, had been deferred. This appears inconsistent with the most frequent response for deferral rates (1-5\%) given by Grantees, Subgrantees and weatherization staff. However, it is possible that the $20 \%$ of Subgrantees reporting deferral rates over $11 \%$ are the agencies with larger populations to serve and higher production, and therefore provided the majority of the occupant survey sample. Interviews conducted with case study agencies and with participants in the deferral special study attributed higher deferral rates during ARRA to pressure on agencies to increase production, and new health and safety guidelines preventing weatherization work from occurring where it might have in the past. Pressure on production levels may have limited time previously spent on attempting to bundle resources necessary to address housing rehabilitation ${ }^{34}$ needs. Lastly, this national deferral rate derived from the occupant survey might differ from the most frequently reported rates given by Grantees, Subgrantees, and staff as a result of lack of tracking or monitoring of this occurrence leaving these entities and individuals to estimate the rates rather than provide accurate rates with more precision.

Despite the majority of homes being deferred for dwelling quality issues, the percentage of households deferred is fairly evenly distributed across household income. This evidence alleviates concerns that WAP does not serve those in greatest need because the homes they reside in are in such poor quality compared to homes in other income brackets ${ }^{35}$. For example, of those deferred, $26 \%$ report income of less than $\$ 10,000$ versus $21 \%$ of households reporting income greater than $\$ 30,000$.

The deferred households are also similar to the served households in many other ways. For example, the temperature and draftiness inside the home is similar. Housing issues are also comparable between the pre-served and deferred group, as indicated by a similar percentage of homes with broken heating or cooling equipment. Served and deferred households are similar in how hard they find it to pay their energy bills. The physical health of the main respondents between the two groups is also similar with a slight increase in percentage (by 4\%) of those with asthma in the deferral group. Households that contain elderly persons, children, and persons with disabilities are deferred at higher rates (43\%, 36\%, and 36\% respectively) than single parent households (at 13\%).

\section{WAP Case Studies Task and Sustainable Energy Resources for Consumers (SERC) Report}

The Case Study ${ }^{36}$ and Program Characterization ${ }^{37}$ assessment reports assist with characterizing the deferral process from the agency perspective. These reports contribute to the overall understanding of

\footnotetext{
${ }^{33}$ See retrospective evaluation report, Carroll et al. (2014a).

${ }^{34}$ For the purposes of this report the terms home rehabilitation (home rehab) and home repair will be used interchangeably.

35 This assertion does not take into account cost of living for particular areas, or household size, but helps to characterize the WAP eligible population deferred weatherization from an income perspective.

${ }^{36}$ See retrospective evaluation report, Tonn, Rose, and Hawkins (2014a).
} 
when and why WAP income-eligible homes might be deferred and how innovative approaches and technologies might address home rehab needs alongside the weatherization process, such as the use of social workers (e.g., see Community Action Partnership, Lewiston in the Case Study report, Tonn, Rose, and Hawkins (2014a)) and the installation of cool roofs (Hawkins et al. 2015). Although the primary intent of WAP and SERC is to improve home energy efficiency, there are multiple co-benefits and opportunities for bundling resources if necessary and available.

\section{Special Study: Agency Interviews}

All of the 43 agencies interviewed used very similar deferral guidelines, regardless of whether they based their standards on state, federal, and/or other deferral guidelines. The most common causes for deferral across all agencies in this sample are roof leaks and structural deficits in the home. Agencies that did not mention either roof leaks or structural deficits as common causes for deferral were in the West and Midwest, and their most common causes for deferral were similar to those stated by the weatherization staff survey; vermiculite, mold/moisture, excessive CO readings, unsanitary conditions, and that the home is too new (nothing to weatherize). Hoarding was also mentioned as a common cause for deferral.

All agencies said they provide clients contact information for outside referral sources (if available) either during the application process or once the deferral has been made. Outside referral sources include any agency, program, or organization which is not part of the interviewed agency itself. Referral information was provided to clients either in the form of a list at the time of the application or audit, as a pamphlet or list mailed with the deferral letter following the audit, or in a phone call to the client following the audit. Some agencies also directly refer clients to in-house resources when those resources are available. Inhouse resources include resources available within the WAP services agency, such as low-interest loan programs available to clients, home rehab programs, and funding from private sources that can be used by the agency to help clients work through home repair issues. Among agencies with in-house funding available to assist with home repairs, there was variation as to the success with which these funds were used to resolve deferral issues.

The majority of Subgrantees stated they never follow up with clients after the clients are deferred services, and only a few agencies indicated that they follow up with clients after making referrals to services to address the cause(s) for the deferral. Follow up with the client after a referral is made appears to be associated with higher success at resolving deferral issues. The agencies that follow up with clients reported that many deferred clients resolve the issues that led to deferrals and return to seek weatherization services. In contrast, the agencies that never follow up with clients after a referral, almost never see clients return to seek weatherization services. The majority of high-success agencies (weatherized over $50 \%$ of homes previously deferred) have in-house resources to refer to. Defunded inhouse home rehab programs contribute to an increase in deferral rates. Having a cross referral partnership with other service organizations did not correlate with high-success for weatherization post-deferral.

\section{Special Study: Client Interviews}

A total of 119 in-depth telephone interviews were conducted with clients in order to discover the way in which they understand and experience the deferral process and to identify the facilitators and barriers to resolving deferral issues and ultimately receiving weatherization services. Review of these interviews revealed some patterns in client deferrals and client response to deferral. Client responses were categorized into three themes: agency-related problems; client-related problems; and resolved deferrals (or clients in the process of resolving their deferrals). Agency-related issues include such problems as: lack of deferral notification, agency not following through with process after client resolves issue, agency

\footnotetext{
${ }^{37}$ See ARRA period report, Tonn, Rose, and Hawkins (2015b).
} 
does not return client calls, referral agencies do not follow through, agency told the client he/she was eligible for weatherization and the agency never followed through, agency did not explain the process in a way that the client can understand, or the agency ran out of funding and denied the client after addressing the initial deferral reasons. Some clients in this category did not attempt to follow up because of health problems, losing agency contact information, or were told from the agency to wait to hear back from them.

Client-related issues include: lack of money or physical ability to complete repairs; landlord not allowing repairs to be made; client no longer interested; or client's home is already up-to-date. The majority of clients in this category mentioned that they do not have the funds necessary to complete the repairs and move forward with the process. The third category involves clients who received full or partial weatherization and consider the process complete, or are currently working to resolve the issue and expect to move forward with the process soon. This is the least common result amongst the three main categories identified in the review of client responses. This group of clients was reviewed in greater detail in an effort to identify specific characteristics or practices of the clients or agencies that might be associated with higher or lower levels of client success at resolving their deferral issue and receiving weatherization. If the issue is less severe and the client understands and is capable of addressing the minor issue, there is greater chance for success with weatherization.

When asked about their support network for assistance with financial, home repairs, or other problems, the majority of clients (62\%) said they have no such support networks, formal or informal. The remaining 38 percent of clients have a person or an organization to turn to for financial support or for help with home repairs. The majority of these clients turn to specific family members such as parents or children, in-laws, or significant others for financial support, help with daily tasks, or to complete home repairs. It is also common for clients to turn to friends for help with home repairs. It is less common that they turn to members of their informal social networks for financial support, but depend more on formal resources for help with repairs or finances such as another local agency or church. A few clients reported a more formal support network to turn to such as another community action agency or other local agency to assist with home repairs. The study shows that the majority of clients rely on the agencies and their potential referral sources in order to move forward with the weatherization process and that they have no one else to turn to for assistance.

\subsection{TERRITORIES STUDY ${ }^{38}$}

This report provides an assessment of the expansion of WAP to U.S. territories specifically for Program Year 2010 and more generally with respect to the Recovery Act ARRA period. Five U.S. territories benefitted from the ARRA period funding for WAP: Commonwealth of Puerto Rico, Guam, the US Virgin Islands, the Commonwealth of the Northern Marianas Islands, and American Samoa. Puerto Rico received just over $\$ 65$ million in funding and weatherized over 15,000 units. The other four received between \$1 and \$2 million in funding and weatherized an average of 590 units.

Most of the research reported on in this report focuses on Puerto Rico's newly developed weatherization program. It is found that the recipients of the program are similar to those served by WAP in the U.S.; elderly individuals, persons with disabilities, and children. The homes in the Puerto Rico program averaged three bedrooms and three other rooms, comparable to WAP homes elsewhere. However, other ways the homes serviced by the Puerto Rico program varied from the national WAP homes. Unlike homes found in the cold region of the U.S., few if any homes weatherized in Puerto Rico had heating systems, central air conditioning or thermostats. Because of the tropical climate installing heating equipment, air sealing measures or insulation was not allowable per DOE approved priority lists. Instead,

\footnotetext{
${ }^{38}$ The text is drawn from the Executive Summary of Tonn and Rose (2015).
} 
the preponderance of homes received rooftop solar water heaters, refrigerators, air conditioners, low-flow faucets, and various baseload measures. Expenditures on health \& safety measures were low (only a percent or two, expect for Guam, which spent about $12 \%$ on health and safety measures per unit) compared to the mainland programs (which averaged 15\%).

Electricity billing histories were collected for over 14,000 weatherized units pre- and post-weatherization. Overall, the average electricity savings was $876 \mathrm{kWh}$ per year, or $15 \%$ of pre-weatherization electricity use. This is considered a conservative estimate of energy saved by the program because energy savings that could be attributed from replacing propane fueled water heaters with rooftop solar water heaters were not measured. It is suggested that the program's savings-to-investment ratio is in the vicinity of 1.34. These results are comparable to energy savings and cost effectiveness of the established weatherization programs found in the rest of the U.S.

Through a client satisfaction survey, it was found that the overwhelming majority of respondents were satisfied or very satisfied with the weatherization program (97\%). Over $90 \%$ reported that the auditors, crews, and inspectors arrived for work on-time or early. Over $25 \%$ of respondents reported that their homes were no longer kept at unsafe temperatures post-weatherization. The number of households reporting that someone needed medical attention from being too hot in their home dropped from $14 \%$ preweatherization to 5\% post-weatherization. Most respondents reported receiving some sort of information about energy use from the program (88\%), but similar to respondents in the continental U.S., few altered their energy use behaviors post-weatherization.

\subsection{WEATHERIZATION POST-RECOVERY ACT SURVEY RESULTS}

The evaluation team administered three surveys to gauge changes in the period after the Recovery Act. One survey was administered to weatherization staff who had participated in a survey a couple of years earlier. A second was administered to individuals who had received training at a DOE weatherization center two years previously. Lastly, the DOE weatherization centers were also surveyed about their postRecovery Act plans. The results of these surveys are summarized below.

\section{Weatherization Staff Survey}

In 2013, the evaluation administered a follow-up survey to all weatherization staff that completed the survey in 2011. The purpose of this survey was primarily to track, two-years later, the employment status of the respondents. There is specific interest in tracking weatherization staff that may have left the field of low-income weatherization. This is because there was some expectation that individuals trained in lowincome weatherization through WAP and DOE weatherization training centers would then go on to careers in non-low-income home retrofit.

In 2011, 882 weatherization staff completed the survey. ${ }^{39}$ Of these respondents, $70 \%$ of the auditors, 58\% of the crew chiefs, and $41 \%$ of the crew members completed the follow-up survey. The employment status of the respondents in 2013 is presented in Table 3.1. In total, 67\% of respondents were still employed by the same agency, $4 \%$ had moved to a different low-income weatherization organization, and $29 \%$ had left the field of low-income weatherization. About a quarter of respondents who were with the same agency had a different job during this time period. Crew members were more likely to have left the field than auditors and crew chiefs.

\footnotetext{
${ }^{39}$ See Carroll et al. (2014c) for the results of the original survey.
} 
Table 3.1 Employment Status of Weatherization Staff Respondents in 2013

\begin{tabular}{|c|c|c|c|c|}
\hline & $\begin{array}{l}\text { Total } \\
(n=508)\end{array}$ & $\begin{array}{l}\text { Auditors } \\
(\mathrm{n}=245)\end{array}$ & $\begin{array}{l}\text { Crew Chiefs } \\
(\mathrm{n}=156)\end{array}$ & $\begin{array}{l}\text { Crew Members } \\
\qquad(\mathrm{n}=107)\end{array}$ \\
\hline Same Agency & $67 \%$ & $69 \%$ & $72 \%$ & $57 \%$ \\
\hline Same Agency, Same Job & $76 \%$ & $74 \%$ & $80 \%$ & $73 \%$ \\
\hline Same Agency, Different Job & $24 \%$ & $26 \%$ & $20 \%$ & $27 \%$ \\
\hline $\begin{array}{l}\text { Different Low-income Weatherization } \\
\text { Organization }\end{array}$ & $4 \%$ & $6 \%$ & $1 \%$ & $3 \%$ \\
\hline Left Low-Income Weatherization & $29 \%$ & $25 \%$ & $27 \%$ & $40 \%$ \\
\hline
\end{tabular}

One can ask whether employment tenure and age of respondent are related to employment status. From Table 3.2, it is apparent that those who left their agencies and the field of low-income weatherization had less time at their agencies and in the field. The weatherization network was in the process of down-sizing from its ARRA period peak in 2013 and it is not surprising that those with less tenure might be more likely to have left their jobs. Crew members in particular had few years invested in their agencies and careers in low-income weatherization.

Of the 146 that left the field of low-income weatherization, only 7 reported working in the home retrofit field. Thus, there is little support from this survey that the surge in employment and training in the national low-income weatherization network has benefited the non-low-income home retrofit market. About one-fifth of the respondents moved into the construction industry and four reported working in the clean energy sector. The balance of the remaining $(n=107)$ respondents reported taking a mixture of other jobs, including these verbatim reports: security guard, sales, retail, janitor, book making, custom furniture builder, food service, health care, landfill, paper mill, real estate, recycling, and lending. Fifty-five percent of the respondents reported being employed or self-employed, $32 \%$ out of work, $7 \%$ retired and $2 \%$ unable to work. Those having health insurance decreased from about $90 \%$ in 2011 to $72 \%$ in 2013 . The average reported income for those employed was unchanged from 2011 but the range of incomes increased: some benefited greatly from the move out of low-income weatherization and some saw a significant decrease in their income. 
Table 3.2 Employment Tenure and Age of Respondents in 2011

\begin{tabular}{|c|c|c|c|c|c|}
\hline & & $\begin{array}{l}\text { Same Agency, } \\
\text { Same Job }\end{array}$ & $\begin{array}{l}\text { Same Agency, } \\
\text { Different Job }\end{array}$ & $\begin{array}{c}\text { Different } \\
\text { Weatherization } \\
\text { Org. } \\
\end{array}$ & $\begin{array}{l}\text { Left Low-Income } \\
\text { Weatherization }\end{array}$ \\
\hline \multirow{4}{*}{$\begin{array}{l}\text { Years at } \\
\text { Agency }\end{array}$} & Total & 8.5 & 8.5 & 6.7 & 4.7 \\
\hline & Auditors & 9.3 & 8.6 & $*$ & 5.9 \\
\hline & Crew Chief & 9.2 & 6.7 & $*$ & 5.3 \\
\hline & Crew Member & 4.9 & 7.5 & $*$ & 2.3 \\
\hline \multirow{4}{*}{$\begin{array}{l}\text { Years in Low- } \\
\text { Income } \\
\text { Weatherization }\end{array}$} & Total & 8.7 & 8.4 & 8.3 & 5.2 \\
\hline & Auditors & 9.8 & 10.0 & $*$ & 6.8 \\
\hline & Crew Chief & 9.2 & 6.7 & * & 5.6 \\
\hline & Crew Member & 4.8 & 7.5 & $*$ & 2.7 \\
\hline \multirow{4}{*}{ Age } & Total & 46 & 43 & 45 & 46 \\
\hline & Auditors & 46 & 43 & * & 51 \\
\hline & Crew Chief & 47 & 46 & $*$ & 44 \\
\hline & Crew Member & 43 & 38 & * & 42 \\
\hline
\end{tabular}

*sample size too small for estimation

\section{Weatherization Trainees Survey}

In 2011, 837 individuals who received training at DOE weatherization centers participated in a survey about their training and experiences. ${ }^{40}$ The follow-up survey targeted younger individuals who may have received training early in their low-income weatherization careers or as a precursor to employment in this sector. Re-contacting this group proved much more difficult than re-contacting the weatherization staff survey sample. Of the 265 targeted for a follow-up survey, good contact information was available for only 177 and only $21 \%$ of those contacted completed the follow-up survey.

Nevertheless, results from this survey provided researchers the opportunity to track jobs a small number of trainees acquired through the training received, to provide insights into different career paths they may take, and to establish the degree with which the trainees contracted with low-income weatherization providers post-ARRA. Exogenous factors such as local economic conditions posing opportunities or constraints for the trainees during the two years after the initial survey was administered were not controlled for.

Survey results revealed a slight shift away from being employed for wages to being self-employed and the rate of trainee unemployment increased by ten percent (See Figure 3.1). The increase in unemployment rates may have been due to the end of ARRA funding. By the summer of 2013, most states and agencies were back to pre-ARRA funding levels or less.

\footnotetext{
${ }^{40}$ See Hawkins et al. (2014) for the results of the original survey and a summary of the follow-up survey.
} 


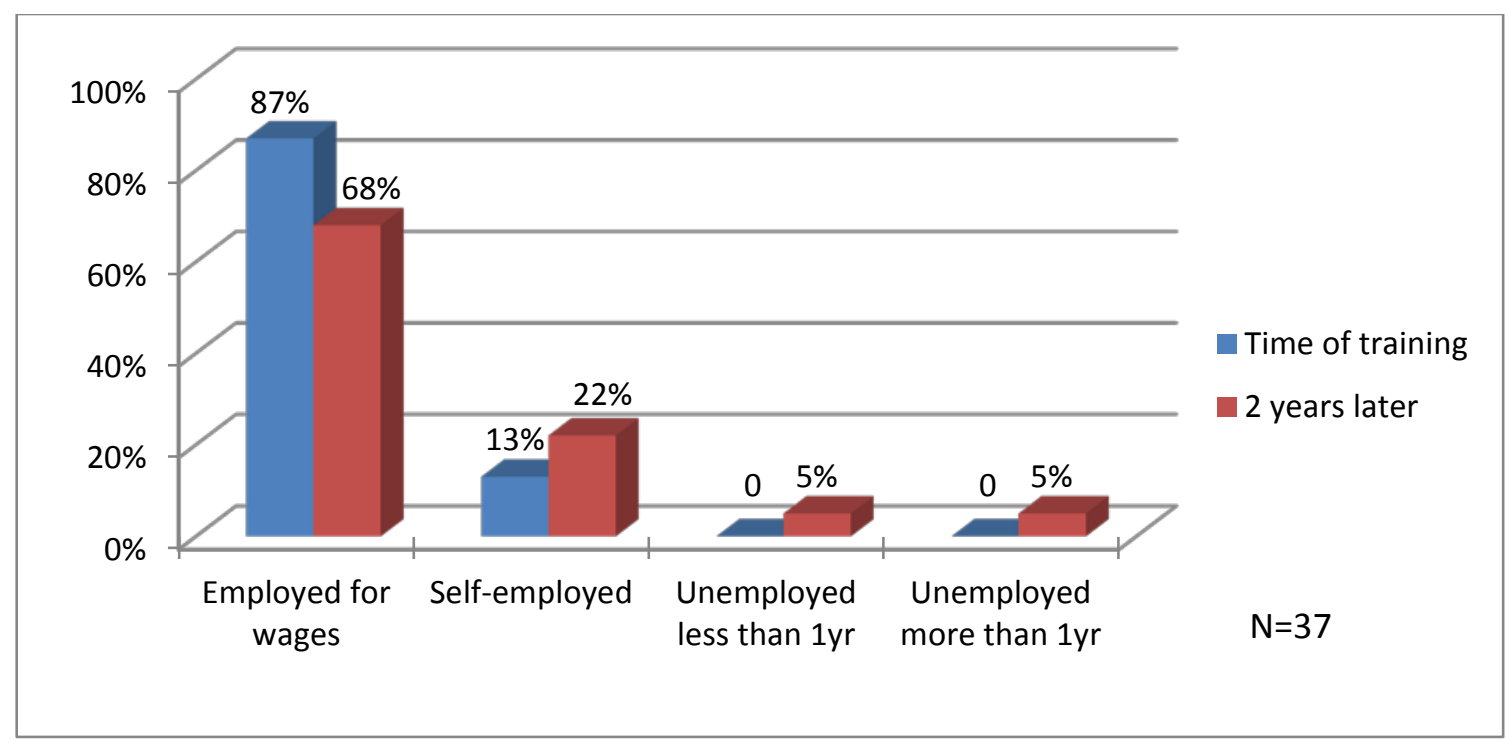

Figure 3.1. Employment status at time of training and two years later

All 37 trainees that took part in the follow-up survey reported they were working in low-income weatherization at the time of the training; two years later four were unemployed and thirteen of these trainees had moved out of this industry. This rate of departure from low-income weatherization (47\%) is similar to the departure rate for weatherization crew members provided above. Of the 13 (See Figure 3.2), eight are now in the private sector (four general contractors, three home retrofit contractors and one reported "other"). Of the other five no longer in low-income weatherization one now works with the local government (still in construction), one with a for-profit firm (chemical transport company); and three reported "other" (construction project manager, factory employee, and general home repair services). It is unknown if these trainees switched careers due to lay-offs by low-income weatherization providers or if this career change was their intended goal.

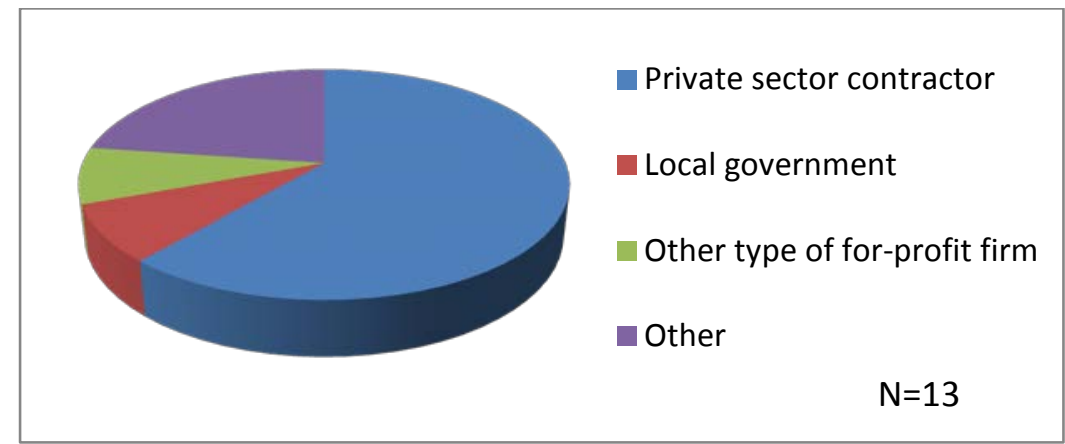

Figure 3.2. Current employers of trainees no longer working in low-income weatherization

Figure 3.3 shows that out of the 20 trainees that are still providing low-income weatherization services, ten currently work for a weatherization agency (at the time of training there were 14 working with a local agency), seven now work for a private weatherization contractor (four had already been working for, or as, a private contractor, three had previously been working with an agency), and three reported "other" (one had previously been working with an agency as an intake specialist and is now a senior field supervisor with a utility company. The other two had previously reported "other" at the time of training). 


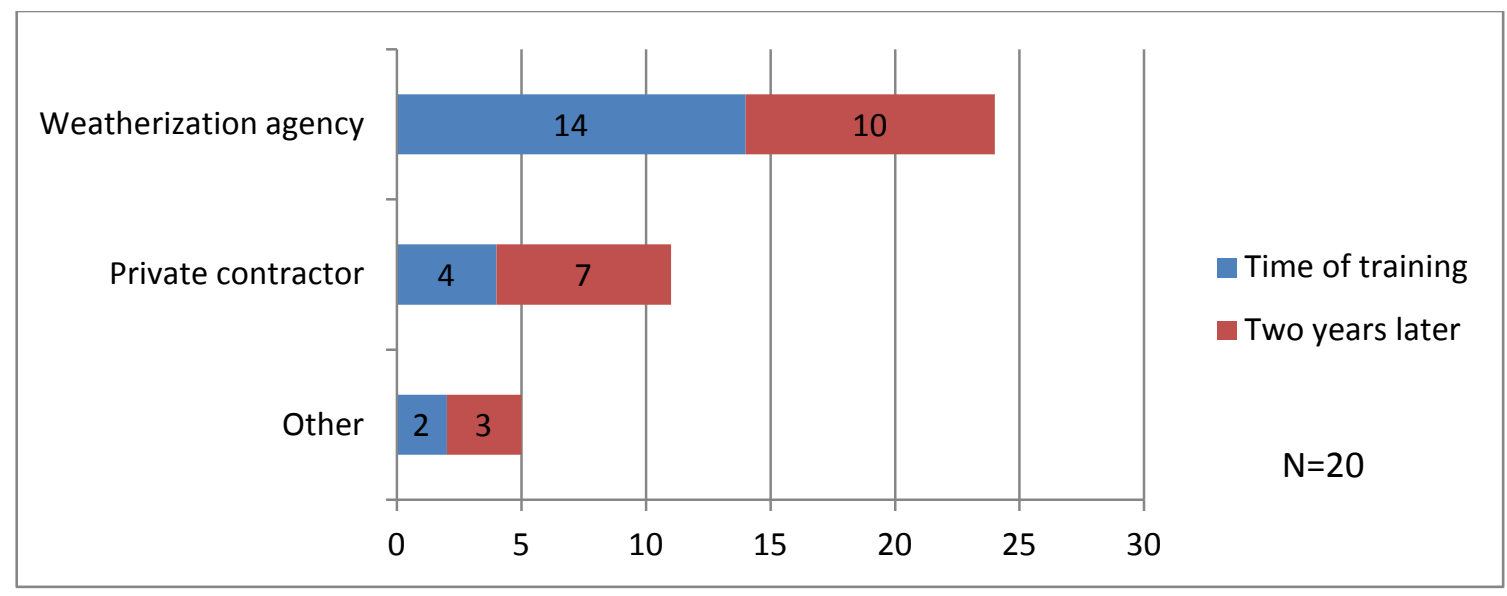

Figure 3.3. Current employers of trainees still working in low-income weatherization

When the trainees were presented with the question; "Has your weatherization training increased your ability to perform at your current job?” 76 percent stated in the affirmative (See Figure 3.4). Specific abilities that would contribute to an increase in performance were not provided.

When asked; “Has your weatherization training increased your ability to get a better job?” 49 percent responded positively as well (See Figure 3.5)

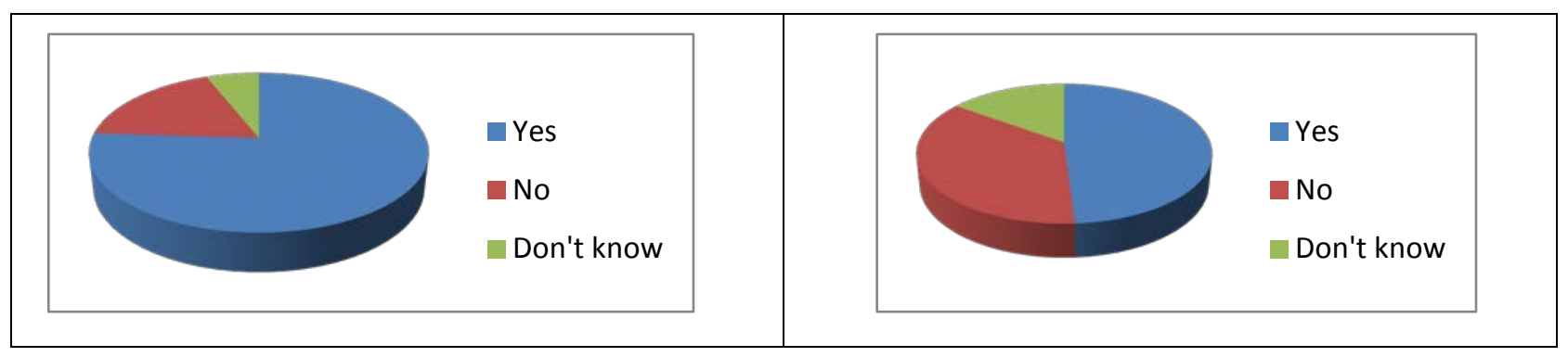

Figure 3.4. Increased Performance

Figure 3.5. Increased Marketability

\section{Weatherization Training Centers}

This report summarizes findings from a survey administered in 2012 to directors of DOE weatherization training centers (Conlon and Tonn 2015). ARRA funding led to a substantial increase in training centers' funding, staffing, classes and certifications offered, and individuals trained. During this period of time, the average Center offered training on approximately 50 topics and 84\% offered at least one Building Performance Institute (BPI) certificate. Activity levels post-ARRA seemed to stabilize at just about preARRA levels, though one-third of the training centers reported a high risk of closure if new sources of funding could not be found. The training centers are split on their forecasts on demands for their services over the next several years. Close to $80 \%$ believe it will be difficult to recruit new trainees.

The results from the weatherization staff and trainee surveys suggest that the training centers face a catch22 situation. Many individuals were trained to work in the general home retrofit sector. This sector has not emerged as quickly as anticipated, though trained workers are required to foster market transformation. Prospective trainees seem to recognize this situation, according to the Centers, and may be shying away from gaining weatherization training. 


\subsection{AC PILOT STUDY ${ }^{41}$}

The study described here was a pilot effort to investigate the efficacy of methods to monitor cooling electricity consumption and savings from homes treated under the federal Weatherization Assistance Program. Twelve homes were recruited for the study, of which eleven had monitoring equipment installed to track cooling-system and whole-house electricity consumption before and after weatherization. Indoor and outdoor temperature and humidity were also tracked. The homes were located in Kansas, Florida and Arizona. Ten of the eleven homes had a central cooling system (either a package unit combining a refrigerant system and air handling equipment or a central split system in which the refrigerant system and air handler were separate); one home used room air conditioners prior to weatherization, and a heat pump following weatherization.

There were issues leading to incomplete data recovery for six of the 11 sites. Pre-weatherization, normalized seasonal (April through October) cooling consumption ranged from less than 1,000 kWh to more than 10,000 kWh among the sites. For the six sites with adequate pre- and post-weatherization cooling-system monitoring data, weatherization was associated with reductions in seasonal coolingsystem energy use of between 20 and 40 percent. Key weatherization measures for these sites included cooling system replacement ( 3 sites), ceiling insulation (4 sites), air sealing (5 sites) and duct repair (2 sites).

The study indicates that cooling-system electricity consumption can be reasonably weather normalized using outdoor temperature or cooling degree days; more complicated approaches that used indoor/outdoor temperature difference or included outdoor humidity resulted in very similar estimates in most cases.

However, two sites exhibited seasonal differences in the relationship between daily cooling electricity and outdoor temperature, which could stem from differences in sun angles or other factors. This suggests that split-season studies of weatherization savings may be less reliable than approaches in which the pre- and post-weatherization periods each encompass a full cooling season.

The data gathered for the project suggest that central cooling system energy use can be adequately estimated from interval data on compressor current draw, allowing for reduced monitoring equipment costs compared to tracking actual kWh consumption. Estimates of seasonal cooling energy use derived from daily whole-house electricity consumption and monthly utility histories generally agreed reasonably with values from direct monitoring of the cooling system, but confounding effects from other end-uses sometimes created differences.

\subsection{REFRIGERATOR STUDY ${ }^{42}$}

This study assesses the characteristics and performance of refrigerators found in a sample of homes eligible to receive WAP services. The refrigerators studied for this research were located in homes that participated in a larger study of the impacts of weatherization on indoor air quality. The study primarily focuses on a set of 382 primary refrigerators and data collected about their operation pre-weatherization. The typical refrigerator found in the study homes was manufactured after the year 2000, has a capacity of 18 cubic feet, and has a top freezer. Only $27 \%$ of the primary refrigerators are located in kitchens and $34 \%$ are not located in conditioned spaces. Only $23 \%$ of the refrigerators had an energy-saver switch and of these, only $48 \%$ of the switches were observed to be in the on position. The preponderance of the refrigerators' inside temperatures was below the recommended $42{ }^{\circ} \mathrm{F}$, though this threshold was exceeded the entire metering time for three refrigerators. The average annualized electricity consumption for a refrigerator in the sample was $756 \mathrm{kWh} /$ year. The median was $651 \mathrm{kWh} /$ year. The variation in

\footnotetext{
${ }^{41}$ See Pigg (2015).

${ }^{42}$ See Tonn and Goeltz (2015)
} 
consumption has many possible explanations, including: refrigerator capacity, age, indoor temperatures, location in unconditioned spaces, number of individuals in the household (e.g., influencing the number of door openings), number of operating options, and simple disrepair. It should be noted that the average electricity consumption of this set of refrigerators is possibly an underestimate given that the data were collected during the winter, the majority of the study houses are located in cold to very cold climates, and a large percentage of the refrigerators are located in unconditioned spaces. As expected, the age and capacity of refrigerators are positively and statistically related to annual energy use. Somewhat unexpectedly, refrigerators that operate at unhealthy temperatures for much of the time use less energy on average. 


\section{CONCLUSIONS}

It was a hectic time for the national weatherization community during the Recovery Act period. Grantees and Subgrantees substantially ramped up their programs to meet employment expectations and production goals. The U.S. territories joined the weatherization network during this period. The network dealt with provisions of the Davis-Bacon Act, increased attention paid to their programs by the media, and increased oversight.

The energy savings estimates by housing type and climate zone are comparable to energy savings achieved during the period prior to the Recovery Act, especially given a relatively inexperienced workforce and an expansion of weatherization in the hot climate zones. Overall, Subgrantees improved their use of diagnostic tools during audits, though more work is needed to improve client education and communication of deferral decisions.

A strong message that can be drawn from the special studies is that low-income weatherization produces non-energy benefits. The study of the Opportunity Council's Weatherization Plus Health program indicates that basic weatherization combined with asthma reduction measures have the potential to significantly reduce Medicaid costs associated with childhood asthma. The social network study concluded that communications from weatherization recipients to members of their social networks create weatherization and energy behavior change multiplier effects. Additional analysis of the occupant survey data identified subgroups within the WAP population that suffer more serious household budget and health issues than other subgroups. Weatherization of their homes has the potential to amplify weatherization's social and household non-energy benefits.

The national weatherization network is adjusting to the post-ARRA funding environment. Many weatherization training centers are facing the risk of closure. From the weatherization staff survey, it was learned that significant numbers of staff have not only left jobs at their local weatherization agencies but have left the home retrofit field altogether. A similar picture emerged from the post-ARRA survey of the weatherization center trainees. This apparent lack of jobs is a worry for the training centers because it will make recruiting new trainees much more difficult.

When combined, the ARRA period and retrospective evaluations of WAP addressed almost every aspect of the program, from energy savings to non-energy benefits to quality of work in the field. A couple of research questions that remain include measuring the persistence of energy savings over time and better understanding the relationships between weatherization and indoor air quality. Answers to the first question could benefit utility planners, those in the voluntary carbon market that may be considering investing in low-income weatherization, and the program by indicating how many years postweatherization a home could be eligible for re-weatherization. Answers to the latter could provide more insights, for example, into the differential benefits of various ventilation solutions given house type, climate, and existing indoor air quality conditions.

With respect to future evaluations, a major challenge faced by the evaluation team was the collection of utility bills. By-and-large, the utility world was amazing cooperative. When there were issues, they tended to fall into two categories. One is related to utility bill waivers that utilities need before they will release utility bill information. In many instances, the Subgrantees simply forgot to ask their weatherization clients to sign waivers. In other cases, utilities rejected the standard waivers used by Subgrantees, either because of internal legal opinion or because of their interpretations of their state's evolving privacy laws, for instance. These barriers proved impossible to overcome in many instances. Moving forward, the program might consider working with utility groups to develop a national standard for utility waivers that the program could then adopt for future evaluations. 
Approximately forty states shared their state weatherization databases with the evaluation team. Though these databases came in a variety of formats, the team was able to extract information from the databases to pre-populate the Grantee and Subgrantee surveys and the data forms. This saved everyone time and money. The program might consider working with states to increase the usefulness of their databases for future evaluations.

The most challenging house type to evaluate by far was the large multifamily sector. This is primarily due to the diversity of utility billing arrangements. For example, many large multifamily buildings are centrally heated and also have central hot water. Residents in these buildings see these costs reflected in their monthly rent. In these buildings, electricity costs may also be included in the rent or may be directly billed to residents. In other buildings, residents are billed directly for all utilities. Most of these buildings have common areas that consume energy and have their own utility billing idiosyncrasies. Many of the buildings in the northeast heat with fuel oil, which poses additional challenges with respect to energy bill collection and energy consumption estimation. To overcome these challenges, the research team dispatched staff to Subgrantees and also to individual multifamily buildings to collect information. This was time consuming and expensive. The program might consider a provision in its large multifamily protocols to require property owners to maintain a file of utility records, fuel oil purchases, etc. that evaluators could access for future evaluations.

In hindsight, there are a number of evaluation design decisions that could have made differently had there not been time and funding constraints. These include:

- Surveying occupants of small multifamily and especially large multifamily buildings about their energy use behaviors and health pre- and post-weatherization;

- Collecting utility bills pre- and post-weatherization for all homes included in the occupant surveys;

- As part of the Field Process Study, follow a group of homes from intake to final inspection to fully assess how homes and their occupants are treated; and

- Deploy measurement devices for much longer periods of time to study the impacts of weatherization on indoor environmental quality. 


\section{REFERENCES}

\section{Recovery Act Evaluation Reports}

Blasnik, M., Dalhoff, G., Carroll, D., Ucar, F., Bausch, D., and Johnson, D. 2015a. "Evaluation of the National Weatherization Assistance Program During Program Years 2009-2011 (American Recovery and Reinvestment Act Period): Energy Impact for Mobile Homes. ORNL/TM-2014/558, Oak Ridge National Laboratory, Oak Ridge, TN, July.

Blasnik, M., Dalhoff, G., Carroll, D., Ucar, F., and Bausch, D. 2015b. Evaluation of the National Weatherization Assistance Program During Program Years 2009-2011 (American Recovery and Reinvestment Act Period): Energy Impacts for Single Family Homes. ORNL/TM-2014/582, Oak Ridge National Laboratory, Oak Ridge, TN, July.

Carroll, D. and Bausch, D. 2015. Environmental Emissions Nonenergy Benefits Working Paper: ARRA Period. ORNL/TM-2015/127, Oak Ridge National Laboratory, Oak Ridge, TN, July.

Carroll, D., Dalhoff, G., Johnson, D., Bausch, D., and Blasnik, M. 2015a. Energy Impacts for Multifamily Buildings: Evaluation of the National Weatherization Assistance Program During Program Years 2009-2011 (American Recovery and Reinvestment Act Period). ORNL/TM-2014/583, Oak Ridge National Laboratory, Oak Ridge, TN, July.

Conlon, B. and Tonn, B. 2015. Findings from Survey Administered to Weatherization Training Centers. ORNL/TM-2015/84, Oak Ridge National Laboratory, Oak Ridge, TN, July.

Pigg, S. 2015. National Weatherization Assistance Program Impact Evaluation - A Pilot Monitoring Study of Cooling System Consumption and Savings under the WAP Program. ORNL/TM-2014/339, Oak Ridge National Laboratory, Oak Ridge, TN, July.

Rose, E., Hawkins, B., Tonn, B., Paton, D. and Shah, L. 2015a. Exploring the Potential of Weatherization and Healthy Homes Interventions on Asthma-related Medicaid Claims and Costs in a Small Cohort in Washington State. ORNL/TM-2015/213, Oak Ridge National Laboratory, Oak Ridge, TN, July.

Rose, E., Hawkins, B., Tonn, B., Conlon, B., Treitler, I. 2015b. Assessing the Potential of Social Networks as a Means for Information Diffusion - the Weatherization Experiences (WE) Project. ORNL/TM-2014/405, Oak Ridge National Laboratory, Oak Ridge, TN.

Rose, E., Hawkins, B., Tonn, B., Ashcraft, L., and Miller, C. 2015c. Exploratory Review of State, Agency and Client Experiences with Deferred Services Under the Weatherization Assistance Program. ORNL/TM-2014/364 Oak Ridge National Laboratory, Oak Ridge, TN, July.

Tonn, B. and Goeltz, R. 2015. National Weatherization Assistance Program Evaluation: Assessment of Refrigerator Energy Use. ORNL/TM-2015/150, Oak Ridge National Laboratory, Oak Ridge, TN, March.

Tonn, B. and Rose, E. 2015. U.S. Territories and Weatherization Assistance Program During the Recovery Act Period. ORNL/TM-2014/592, Oak Ridge National Laboratory, Oak Ridge, TN, March.

Tonn, B., Rose, E., and Hawkins, B. 2015a. Survey of Recipients of Weatherization Assistance Program Services: Assessment of Household Budget and Energy Behavior Pre- to Post-Weatherization.

ORNL/TM-2015/64, Oak Ridge National Laboratory, Oak Ridge, TN, March. 
Tonn, B., Rose, E., and Hawkins, B. 2015b. National Weatherization Assistance Program Characterization Describing the Recovery Act Period. ORNL/TM-2015/195, Oak Ridge National Laboratory, Oak Ridge, TN, March.

Tonn, B., Rose, E., Schmoyer, R., Eisenberg, J., Ternes, M., Schweitzer, M., and Hendrick, T., 2011. Evaluation of the National Weatherization Assistance Program During Program Years 2009-2011 (American Recovery Act and Reinvestment Period). ORNL/TM-2011/87, Oak Ridge National Laboratory, Oak Ridge, TN, December.

\section{Retrospective Evaluation Reports}

Bensch, I., Keene, A., Cowan, C., and Koski, K. 2014. National Weatherization Assistance Program Characterization: Describing the Pre-ARRA Program. ORNL/TM-2013/188, Oak Ridge National Laboratory, Oak Ridge, Tennessee, April.

Berger, J., Lenahan, T., and Carroll, D. 2014. National Weatherization Assistance Program Process Field Study: Findings from Observations and Interviews at 19 Local Agencies Across the Country. ORNL/TM2014/304, Oak Ridge National Laboratory, Oak Ridge, Tennessee, September.

Blasnik, M., Dalhoff, G., Carroll, D., and Ucar, F. 2014a. National Weatherization Assistance Program Impact Evaluation - Energy Impacts for Mobile Homes. ORNL/TM-2014/84, Oak Ridge National Laboratory, Oak Ridge, Tennessee, November.

Blasnik, M., Dalhoff, G., Carroll, D., and Ucar, F. 2014b. National Weatherization Assistance Program Impact Evaluation: Energy Impacts for Small Multifamily Buildings. ORNL/TM-2014/325, Oak Ridge National Laboratory, Oak Ridge, Tennessee, September.

Blasnik, M., Dalhoff, G., Carroll, D., and Ucar, F. 2014c. National Weatherization Assistance Program Impact Evaluation: Energy Impacts for Large Multifamily Buildings. ORNL/TM-2014/332, Oak Ridge National Laboratory, Oak Ridge, Tennessee, September.

Blasnik, M., Dalhoff, G., Pigg, S., Mendyk, A., Carroll, D., and Ucar, F. 2014d. National Weatherization Assistance Program Impact Evaluation: Energy Impacts for Single Family Homes. ORNL/TM-2015/13, Oak Ridge National Laboratory, Oak Ridge, Tennessee, September.

Burton, M. et al. 2014. Macro-economic Impacts of the Weatherization Assistance Program for PY 2008. ORNL/TM-2014/98, Oak Ridge National Laboratory, Oak Ridge, Tennessee, September.

Carroll, D., Berger, J., Miller, C., and Driscoll, C. 2014a. National Weatherization Assistance Program Impact Evaluation - Baseline Occupant Survey: Assessment of Client Status and Needs. ORNL/TM2015/22, Oak Ridge National Laboratory, Oak Ridge, Tennessee, October.

Carroll, D., Berger, J., Miller, C., and Driscoll, C. 2014b. National Weatherization Assistance Program Impact Evaluation - Client Satisfaction Survey: WAP Service Delivery from the Client's Perspective. ORNL/TM-2014/335, Oak Ridge National Laboratory, Oak Ridge, Tennessee, September.

Carroll, D., Berger, J., Miller, C., and Johnson, DB. 2014c. National Weatherization Assistance Program Impact Evaluation: Weatherization Staff Survey. ORNL/TM-2014/323, Oak Ridge National Laboratory, Oak Ridge, Tennessee, September. 
Carroll, D., Kim, C., and Driscoll, C. 2014d. National Weatherization Assistance Program Impact Evaluation: Eligible Population Report. ORNL/TM-2014/312, Oak Ridge National Laboratory, Oak Ridge, Tennessee, September.

Carroll, D. et al. 2014e. Environmental Emissions Nonenergy Benefits: Working Paper. ORNL/TM2015/126, Oak Ridge National Laboratory, Oak Ridge, Tennessee, September.

Hawkins, B., Tonn, B., and Bensch, I. 2014. Findings from Survey Administered to Trainees of Weatherization Training Centers. ORNL/TM-2014/306, Oak Ridge National Laboratory, Oak Ridge, Tennessee, September.

Pigg, S., Cautley, D., Francisco, P. with Hawkins, B., and Brennan, T. 2014a. Weatherization and Indoor Air Quality: Measured Impacts in Single-Family Homes Under the Weatherization Assistance Program. ORNL/TM-2014/170, Oak Ridge National Laboratory, Oak Ridge, Tennessee, September.

Pigg, S. 2014b. National Weatherization Assistance Program Impact Evaluation: Impact of Exhaust-Only Ventilation on Radon and Indoor Air Quality - A Field Investigation. ORNL/TM-2014/367, Oak Ridge National Laboratory, Oak Ridge, Tennessee, September.

Pigg, S. 2014c. National Weatherization Assistance Program Impact Evaluation: A Field Investigation of Apparent Low and High Savers. ORNL/TM-2014/308, Oak Ridge National Laboratory, Oak Ridge, Tennessee, October.

Ternes, M., Schweitzer, M., Tonn, B., Schmoyer, R., and Eisenberg, J. 2007. National Evaluation of the Department of Energy's Weatherization Assistance Program (WAP): Program Year 2006 Experimental Plan. ORNL/CON-498, Oak Ridge National Laboratory, Oak Ridge, TN, February.

Tonn, B., Rose, E., and Hawkins, B. 2014a. Weatherization Beyond the Numbers: Case Studies of Fifteen High-Performing Weatherization Agencies - Conducted May 2011 Through July 2012. ORNL/TM2014/317, Oak Ridge National Laboratory, Oak Ridge, Tennessee, September.

Tonn, B., Rose, E., Hawkins, B., and Conlon, B. 2014b. Health and Household-Related Benefits Attributable to the Weatherization Assistance Program. ORNL/TM-2014/345, Oak Ridge National Laboratory, Oak Ridge, Tennessee, September.

Tonn, B., Carroll, D., Pigg, S., Blasnik, M., Dalhoff, G., Berger, J., Rose, E., Hawkins, B., Eisenberg, J., Umar, F., Bensch, I., and Cowan, C. 2014c. Weatherization Works - Summary of Findings from the Retrospective Evaluation of the U.S. Department of Energy's Weatherization Assistance Program. ORNL/TM-2014/338, Oak Ridge National Laboratory, Oak Ridge, Tennessee, September.

Treitler, I., Gregory, J. with Rose, A. and Schilling, P. 2013. Personal Insights and Anecdotes about the Weatherization Assistance Program. ORNL/TM-2015/21, Oak Ridge National Laboratory, Oak Ridge, Tennessee, July.

\section{Other References}

Brown, M., Berry, L., and Kinney, L. 1994. Weatherization Works: Final Report of the National Weatherization Evaluation. ORNL/CON-395, Oak Ridge National Laboratory, Oak Ridge, TN, September. 
Hawkins, B., Rose, E., Tonn, B., Lenahan, T., Bausch, D., and Carroll, D. 2015. Assessment of U.S. Department of Energy’s Sustainable Energy Resources for Consumers Grant Program. ORNL/TM2015/160, Oak Ridge National Laboratory, Oak Ridge, Tennessee, August (Draft). 



\section{APPENDIX. SUMMARY OF ARRA PERIOD EVALUATION DATA COLLECTION ACTIVITIES}





\section{APPENDIX. SUMMARY OF ARRA PERIOD EVALUATION DATA COLLECTION ACTIVITIES}

The ARRA period evaluation of DOE's WAP entailed a large and comprehensive data collection effort. Table A.1 lists the major data collection activities that were national in scope. Table A.2 lists the data collection activities undertaken by the numerous field studies. Details about the sample selection methodologies can be found in Tonn et al. (2011). Details about response rates and other issues related to the administration of the information collection instruments and methods are contained in the individual reports.

Table A.1. Major Data Collection Activities

\begin{tabular}{|c|c|c|}
\hline S1 & $\begin{array}{l}\text { Grantees Program } \\
\text { Information Survey }\end{array}$ & $\begin{array}{l}\text { All Grantees were asked to complete this web-based survey } \\
\text { about program finances, leveraging, program procedures and } \\
\text { training. }\end{array}$ \\
\hline S2 & $\begin{array}{l}\text { Subgrantees Program } \\
\text { Information Survey }\end{array}$ & $\begin{array}{l}\text { All Subgrantees were asked to complete this web-based survey } \\
\text { about program finances, and leveraging. }\end{array}$ \\
\hline S3 & $\begin{array}{l}\text { Subgrantees Detailed } \\
\text { Program Information } \\
\text { Survey }\end{array}$ & $\begin{array}{l}\text { Four hundred and fifty Subgrantees were randomly selected to } \\
\text { complete a detailed, web-based survey about audit procedures, } \\
\text { diagnostics and training. These agencies were also asked to } \\
\text { provide information for DF2, DF3 and DF4 as well as assist with } \\
\text { the S4 and S5 surveys. }\end{array}$ \\
\hline S4 & Occupant Survey & $\begin{array}{l}\text { A random sample of homes about to be weatherized and } \\
\text { weatherized one year previously were selected for this phone } \\
\text { survey that contained questions on energy behavior, health and } \\
\text { safety, demographics and satisfaction with weatherization } \\
\text { services delivered. These homes were surveyed again } \\
\text { approximately eighteen months later. }\end{array}$ \\
\hline S5 & $\begin{array}{l}\text { Weatherization Staff } \\
\text { Survey }\end{array}$ & $\begin{array}{l}\text { A random sample of weatherization auditors, crew chiefs, and } \\
\text { crew were selected for this phone survey that contained } \\
\text { questions on their careers in weatherization, job satisfaction, } \\
\text { training, and in-field experiences. The respondents were } \\
\text { surveyed approximately eighteen months later to track their } \\
\text { career paths. }\end{array}$ \\
\hline DF2 & $\begin{array}{l}\text { Housing Unit } \\
\text { Information Data Form }\end{array}$ & $\begin{array}{l}\text { A random sample of single family and mobile homes } \\
\text { weatherized by the four hundred and fifty Subgrantees during } \\
\text { PY2010 were selected for the Subgrantees to provide details } \\
\text { about what diagnostic procedures were used, what measures } \\
\text { were installed, and job costs. }\end{array}$ \\
\hline DF3 & $\begin{array}{l}\text { Building Information } \\
\text { Data Form }\end{array}$ & $\begin{array}{l}\text { Subgrantees provided for a random sample of small multifamily } \\
\text { and large multifamily buildings on diagnostic procedures, what } \\
\text { measures were installed, and job costs for the selected jobs. }\end{array}$ \\
\hline DF4 & $\begin{array}{l}\text { Subgrantee Utility Bills } \\
\text { Data Form }\end{array}$ & $\begin{array}{l}\text { For each home and multifamily building heated with NG or } \\
\text { electricity that the Subgrantees provided DF2 and DF3 data, the } \\
\text { Subgrantees were also asked to provide information utility } \\
\text { account information. }\end{array}$ \\
\hline DF5 & $\begin{array}{l}\text { Utility Information } \\
\text { Data Form }\end{array}$ & $\begin{array}{l}\text { For each home and building included in DF4, the correct utilities } \\
\text { were asked to complete this data form to provide up to } 60 \\
\text { months of billing histories. }\end{array}$ \\
\hline
\end{tabular}


Table A.2. Field Study Data Collection Activities

\begin{tabular}{|l|l|}
\hline Weatherization Plus Health & $\begin{array}{l}\text { This study collected occupant survey data and Medicaid claims and cost data for } \\
\text { households that participated in the Opportunity Council's Weatherization Plus } \\
\text { Health program and for a small number of comparison homes. }\end{array}$ \\
\hline $\begin{array}{l}\text { Weatherization Experiences } \\
\text { Social Networking Study }\end{array}$ & $\begin{array}{l}\text { This study collected data from over 700 hundred people with whom weatherization } \\
\text { recipients had interacted about their weatherization experiences. }\end{array}$ \\
\hline $\begin{array}{l}\text { Weatherization Deferral } \\
\text { Study }\end{array}$ & $\begin{array}{l}\text { This study collected survey data from households that had their weatherization } \\
\text { services deferred and also from a representative sample of Subgrantees about their } \\
\text { deferral practices and experiences. }\end{array}$ \\
\hline Territories Study & $\begin{array}{l}\text { This study collected occupant and client satisfaction survey data from households } \\
\text { that received weatherization services in Puerto Rico, energy bills from homes } \\
\text { weatherized in Puerto Rico, and S1/S2 survey data from five territorial } \\
\text { weatherization programs. }\end{array}$ \\
\hline AC Pilot Study & $\begin{array}{l}\text { This study monitored electricity consumed by air conditioners in a small number of } \\
\text { homes pre- and post-weatherization. }\end{array}$ \\
\hline Center Trainee Survey & $\begin{array}{l}\text { The Department of Energy's Weatherization Training Centers asked their trainees } \\
\text { to complete a survey post-training about what training the received and their } \\
\text { satisfaction with the training. The trainees were re-contacted approximately } \\
\text { eighteen months later to collection information on career paths. }\end{array}$ \\
\hline Refrigerator Study & $\begin{array}{l}\text { As part of the Indoor Environmental Quality Study, data will collected about } \\
\text { refrigerators residing in treatment homes, including age, inside temperature, and } \\
\text { energy use. These data are analyzed as part of this study. }\end{array}$ \\
\hline
\end{tabular}

